\title{
Structure and function of microbial communities involved in biomineralization
}

\author{
Dissertation \\ for the award of the degree \\ "Doctor rerum naturalium" (Dr.rer.nat.) \\ of the Georg-August-Universität Göttingen
}

within the doctoral program Biology

of the Georg-August University School of Science (GAUSS)

submitted by

Aysha Kamran

from Karachi, Pakistan

Göttingen, 2021 


\section{$\underline{\text { Thesis Committee }}$}

PD Dr. Michael Hoppert, Department of General Microbiology, Institute of Microbiology and Genetics, Georg-August University Göttingen

Prof. Dr. Rolf Daniel, Department of Genomic and Applied Microbiology, Institute of Microbiology and Genetics, Georg-August University Göttingen

Prof. Dr. Volker Thiel, Department of Geobiology, Geoscience Centre, Georg-August University Göttingen

\section{Members of the Examination Board}

Reviewer: PD Dr. Michael Hoppert, Department of General Microbiology, Institute of Microbiology and Genetics, Georg-August University Göttingen

Second Reviewer: Prof. Dr. Rolf Daniel, Department of Genomic and Applied Microbiology, Institute of Microbiology and Genetics, Georg-August University Göttingen

\section{Further members of the Examination Board}

Prof. Dr. Volker Thiel, Department of Geobiology, Geoscience Centre, Georg-August University Göttingen

Prof. Dr. Joachim Reitner, Department of Geobiology, Geoscience Centre, Georg-August University Göttingen

PD Dr. Wilfried Kramer, Department of Molecular Genetics, Institute of Microbiology and Genetics, Georg-August University Göttingen

PD Dr. Heiko Liesegang, Department of Genomic and Applied Microbiology, Institute of Microbiology and Genetics, Georg-August University Göttingen

Date of oral examination: 20.01 .2022 
"You can't go back and change the beginning,

but you can start where you are and change the ending."

C.S. Lewis 


\section{Table of Contents}

Abstract

\section{Chapter 1}

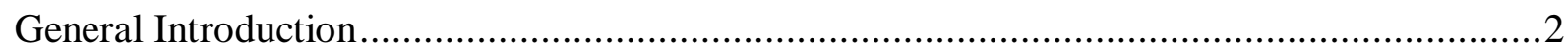

1.1 Carbonate as a part of the global carbon cycle ......................................................2

1.2 Lagerstätten: sites of exceptional fossil preservation .......................................... 3

1.3 Carbonate concretions and other mineral precipitates .........................................

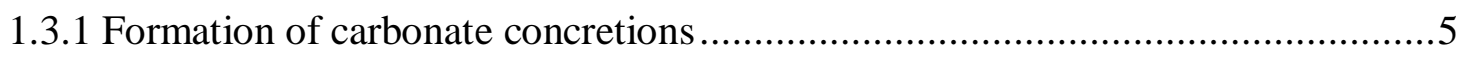

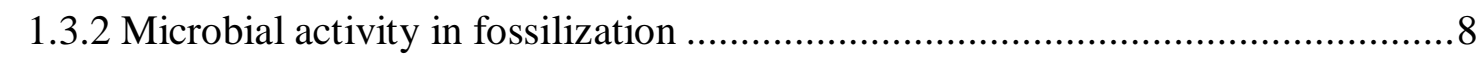

1.4 Extremely alkaline serpentinizing springs .................................................

1.5 Geochemistry in hyperalkaline springs of the Voltri Massif ................................. 12

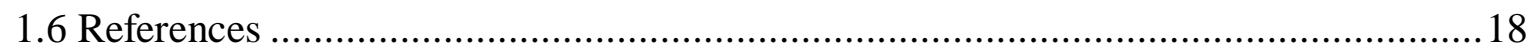

\section{Chapter 2}

Formation of siderite in microbial microcosms derived from a marine sediment

\section{Chapter 3}

Cyanobacterial mats in calcite-precipitating serpentinite-hosted alkaline springs of the Voltri

Massif, Italy

\section{Chapter 4}

General Discussion

4.1 Carbonate precipitates encasing and conserving biomass.

4.1.1 Occurrence of carbonate concretions in sediments .62

4.2 Microbial processes involved in iron mineral formation .......................................66 4.3 Carbonate precipitating alkaline spring ….................................................. 70

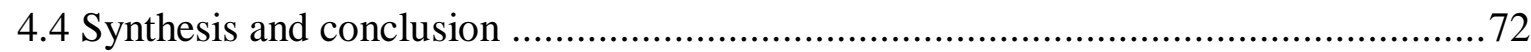

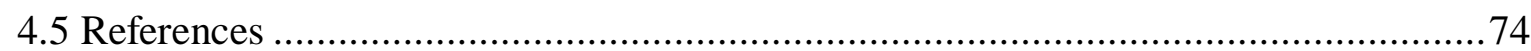

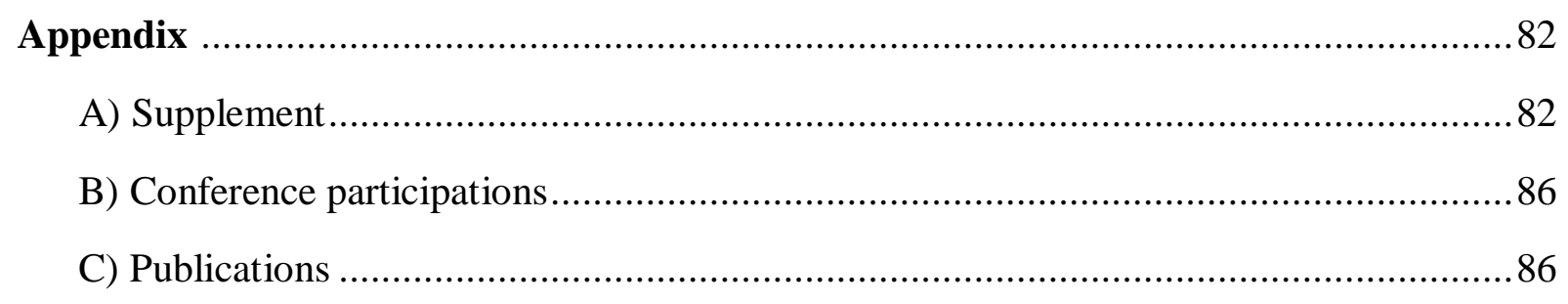

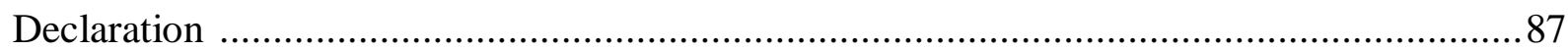

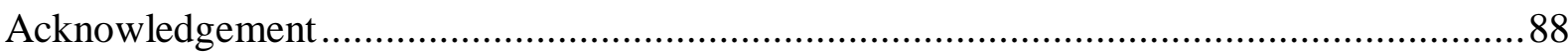

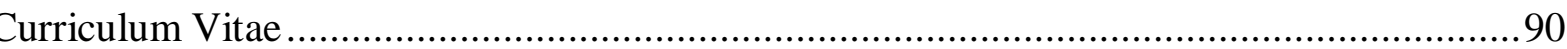




\section{Abstract}

Different aspects of carbonate precipitation are considered in this study. The first part examines carbonates in a model system that helps to explain the initial steps in the formation of so-called concretions, which are solidified sedimentary masses, cemented with carbonate minerals. Formation of carbonate concretions under participation of microorganisms is common in oceans and in freshwater systems and is also considered as an important fossilization process. The role of the involved microbial communities, however, is largely unknown. In this study, siderite $\left(\mathrm{FeCO}_{3}\right)$ formation in microbial microcosms, mimicking processes in marine sediments, is observed. For inoculation, Wadden Sea sediments were used and fatty acyl compounds (lipids, surfactants) served as substrates. In actively growing microcosms, sulfate reducing bacteria (the genus Desulfofrigus in particular) dominate the microbial community. Submicroscopic mineral precipitates forming on bacterial cell surfaces were identified as siderite $\left(\mathrm{FeCO}_{3}\right)$. This biologically influenced mineralization process may, in the natural environment, initiate the formation of large concretions under suboxic conditions in coastal sediments.

In the second part of this study, a natural carbonate precipitating system was considered. Calcification in terrestrial, highly alkaline springs, is an obvious process; the participation of microorganisms, however, is not well understood. Serpentinization-driven springs of the Voltri Massif (Italy) expel highly alkaline fluids ( $\mathrm{pH} 10-12)$; precipitated calcite forms soft layers and solidified sinter terraces. Metagenomics studies, based on analysis of 16S rRNA amplicons were used for identification of the microbial communities growing as biofilms intermixed with calcite structures. Few cyanobacterial genera dominated these communities. The general discussion considers the formation of organominerals and preservation of biological macromolecules in different carbonate precipitating systems. 


\section{General Introduction}

\subsection{Carbonates as part of the global carbon cycle}

The geobiosphere of the Earth - mainly its uppermost part of the crust - is dominated by sedimentary rocks; many of them are carbonates, calcium carbonate in particular. Carbonates are most important in the global carbon cycle. The physical parameters of our planet's surface (temperature, ion contents, hydrostatic pressure, $\mathrm{pH}$ of water bodies) provide conditions for the coexistence of the water-dissolved (mainly $\mathrm{Ca}^{2+}, \mathrm{HCO}_{3}^{-}$) and gaseous $\left(\mathrm{CO}_{2}\right)$ constituents, as well as for the solid carbonate salt $\left(\mathrm{CaCO}_{3}\right)$ at the same time. These global conditions make the equilibrium between solid/dissolved and gaseous (carbon dioxide) constituents to one of the most important regulators of long-term climate change - after all, most of the carbon dioxide of the geobiosphere is bound in carbonates, originating from rainwater-dissolved carbon dioxide (as hydrogen carbonate) after precipitation with bivalent ions in continental shelves (Ridgwell and Zeebe, 2005). Many organisms participate in the equilibrium between carbonate dissolution and precipitation. Basically, there is no way for organisms to escape from this. Metabolic processes either produce carbon dioxide (respiration, fermentation) or take it from the environment to produce biomass (carbon dioxide fixation) which influences carbonate alkalinity. Other processes influence the $\mathrm{pH}$ value by excretion/consumption of acids. Organisms of any kind produce surface structures with polar or ionic groups, providing matrices for scavenging (calcium) ions and hence for "directed" calcium carbonate (and other mineral) precipitation. Eukaryotic organisms are capable of "molding" shell structures from carbonates, protecting them from, e.g., their predators (cf. Monteiro et al., 2016). Thus many limestone sediments consist mainly, if not completely, of carbonate shells formed by organisms (from unicellular to metazoan stages of organization). 
In systems close to the equilibrium of carbonate precipitation and dissolution, it is rewarding for an animal to form a carbonate shell in terms of the investment of metabolic resources and energy (Clark, 2020). On the other hand, carbonate precipitation may occur inevitably as a side effect of metabolic processes, producing potentially harmful minerals inside or on surfaces of organisms - which is a particular risk for microbes (e.g., Riding, 1978; Dupraz and Visscher, 2006; Spitzer et al., 2015).

In this study, two seemingly different aspects of carbonate precipitation, and involved microbial processes, are considered: (1) the formation of carbonate concretions in early stages of fossilization, triggered by sulfate reducing bacteria and (2) the formation of carbonates in alkaline springs, with an involved cyanobacterial community. Both processes are likely to be in no way beneficial for the microbial cells, because they are encased and killed off when precipitation proceeds. In any case, however, the mixture between carbonate and organic biomass ("organomineral" in a broad sense) is persistent and may be considered as a "time capsule" of different microbial processes.

\subsection{Lagerstätten: sites of exceptional fossil preservation}

In spite of the fact that remains of organisms are present in nearly any kind of sediment, deposits of fossils with exceptional preservation in high quantity provide unique insights into organismic features and biodiversity in Earth's history. Two types of important fossil deposits found in the rock record are known as Konzentrat-Lagerstätten and Konservat-Lagerstätten (Seilacher, 1970). In case of Konzentrat-Lagerstätten, they offer a more comprehensive insight in the diversity of biological communities, compared with other fossil sites (Briggs, 2003). The reason for this is that remains of organisms are concentrated, e.g. in fissures, after having been transported over a wider area (e.g., Sues and Munk, 1996). However, these processes are rather 
unsuitable for preservation of soft tissue and just organic hard parts are accumulated - such as in bone beds. Some Konzentrat-Lagerstätten, like fossil reefs, were formed in situ and provide a more comprehensive picture of the interrelationships between sessile organisms (Bottjer et al., 2002; Allison, 1988a; Gould, 1990).

Konservat-Lagerstätten (Seilacher, 1970) occur relatively rarely and provide exceptionally well-preserved (soft-bodied) fossils (Melendez et al., 2013; Parry et al., 2018). They give important insight into significant time periods in the history and evolution of life, not just because of preservation of morphologies, but also of chemical signatures. For taxonomic analysis, such fossils often give an otherwise missing insight into a complete body (Briggs, 2003), and not just in remains of biomineralized parts, like shells or bones, which are the far more widespread fossils. Generally, soft tissue preservation takes place when these organic parts of an organism are preserved from degradation process long enough to be transformed into recalcitrant material (generally a mineral), or when it becomes secondarily replicated by a mineral which then persists over geologic timescales (Briggs, 2003). The Lagerstätte offers relatively complete insights into the dynamics of ancient ecosystems, as known, e.g., for the Middle Cambrian benthic community of the Burgess Shale (Morris, 1986). As another example, conodont elements, consisting of apatite, are well-preserved and abundant teeth-like microfossils, present in numerous strata from Early Cambrian to Late Triassic. Complete fossils of the animal are virtually unknown because the non-biomineralized body parts are generally rapidly destroyed in most environments. In contrast, conodont animal fossils in the Lower Carboniferous Konservat-Lagerstätte Granton 'shrimp bed' near Edinburgh are well preserved (Zapalski and Clarkson, 2015). Though the biomineralized body parts did not allow any taxonomic implication, the preserved soft tissue of conodont animals revealed their taxonomic affiliation to Chordata (Briggs et al., 1991). 
Another important example is the Upper Carboniferous Mazon Creek Konservat-Lagerstätte harboring an animal and plant community from an estuarine realm. Fossils are preserved by the cementation of iron carbonate around a nucleus of the organic material, which is called (carbonate) concretion (McCoy, 2014; Clements et al., 2019; Grice et al., 2019). Concretions are one focus of this thesis and are presented in detail in the following chapters.

\subsection{Carbonate concretions and other mineral precipitates}

Exceptional preservation of fossils in concretions is based on the encasement mechanism by carbonate around soft tissue as a nucleus (McCoy, 2014). Likely, the mechanism is induced by microbial activity during the degradation process.

In many cases, mineral precipitates and concretions are indicators of the (past) metabolic activity of microorganisms (Mozley and Burns, 1993; Kiriakoulakis et al., 2000; Pearson and Nelson, 2005; Hendry et al., 2006; Vorhies and Gaines, 2009; Gaines and Vorhies, 2016; Thiel and Hoppert, 2018) and due to this they may even provide significant information in search for the evidence of life on other planets (Squyres et al., 2004; Clarke and Stoker, 2011; Potter et al., 2011; Stack et al., 2014). Many carbonate concretions encase fossils in their centers, sometimes even with exceptional soft tissue preservation (Curtis et al., 1986; Mozely and Burns, 1993; Raiswell and Fisher, 2000; Clements et al., 2019).

\subsubsection{Formation of carbonate concretions}

Isotopic analysis revealed microbial activity behind the initial steps in formation of several types of concretions (Irwin et al., 1977; Coleman, 1993): the microbial processes take place in sediments or even in consolidated sedimentary rocks (Raiswell and Fisher, 2000; Gaines and Vorhies, 2016). In fact, microbially induced increase in alkalinity and $\mathrm{pH}$ in the immediate 
environment is of great importance for concretion formation (Curtis et al., 1986; Loyd et al. 2012). Bicarbonate as common metabolic product of anaerobic microbial respiration of organic carbon compounds (e.g., iron reduction, sulfate reduction), but also as a byproduct in fermentative processes sustains, along with a metal counter ion (magnesium, calcium, iron), sustain concretion growth (Canfield et al., 1993; Thamdrup and Canfield, 1996; Raiswell and Fisher, 2000).

Even though formation of concretions have been studied over several decades, there are still remaining questions regarding the formation, growth and why are the concretions are spherical or ovoid-shaped with sharp boundaries (Yoshida et al., 2018). The formation of carbonate concretions usually takes place at the sediment-water interface (SWI) in a dysoxic to anoxic environment (cf. Fig. 1). The microbial process during early diagenesis inevitably takes place within the pore water. The fossilizing organics along with allochthonous organic matter and products of microbial activity (either organic or inorganic), become part of the consolidated concretion, which is the reason why well-preserved carbonate concretions may be considered as "time capsules" for these processes (El Albanni et al., 2001; Dale et al., 2014). Isolation and cementation around biological remains (e.g., soft tissue) protect against the inorganic environment and therefore prevent the complete mineralization of soft tissue and molecules (i.e, degradation to $\mathrm{CO}_{2}$ and $\mathrm{CH}_{4}$ ), allowing them to be preserved for tens of millions of years (Bottjer et al., 2002). Currently, various approaches are used to study the potential of microbial process for their formation, principally focusing on carbon and sulfur stable isotopes and analysis of mineralogy and rare earth elements (REE) as signatures for the process of their generation (Haley et al., 2004; Hendry et al., 2006; Loyd et al., 2012; Dong et al., 2013). The formation of carbonate concretions is commonly facilitated by incorporation of hydrogen carbonate, partly deriving from carbon dioxide as a product of biogenic organic matter 
degradation during the initial process of fossilization. Since the original sedimentary setting is rich in organics, the concretion is, in the end, regularly embedded in an organic-rich mudstone setting (cf. Fig. 2) (Melendez et al., 2013; Gaines and Vorhies, 2016; Plet et al., 2016, 2017; Röhl et al., 2016).

Until now, several experiments to study systematically initial steps of decay and diagenesis was performed with metazoan model organisms (Allison, 1988; Briggs, 1995). Though formation of minerals along with carcass decay was reported within weeks, carbonate concretion growth time is much longer. Time scales given in references vary from tens to hundreds of thousands of years (Berner 1968; Boles et al., 1985; Sellés-Martínez, 1996; Raiswell and Fisher, 2000). This prolonged growth is evidenced by the presence of zoned crystals (Raiswell, 1988; Mozley 1989; Raiswell and Fisher, 2000) and multiple generations of cements with specific chemical and isotopic properties (Hennessy and Knauth, 1985; Feistner, 1989; Mozley, 1989, 1996; Hart et al., 1992; Desrochers and Al Aasm, 1993; Fisher et al., 1998; Hendry et al., 2006; Dale et al., 2014; Loyd et al., 2014; Gaines and Vorhies, 2016). These features could not be observed in model experiments. However, authors repeatedly attempted to correlate long-term concretion formation in natural settings with initial precipitation of a mineral framework over few months (Briggs and Kear, 1994; Gaines et al., 2012a; McCoy et al., 2015a). 


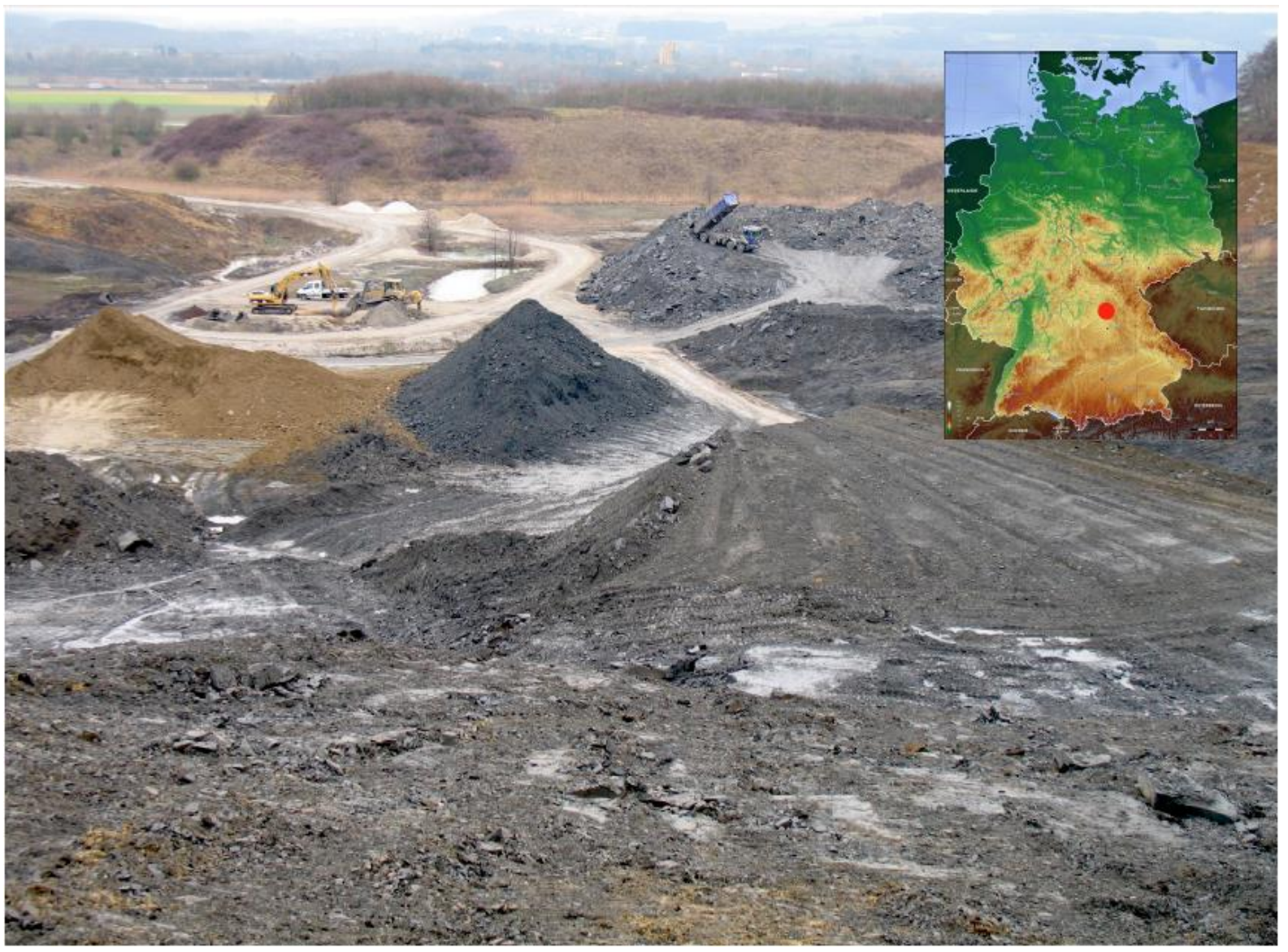

Fig. 1. An open clay pit near Buttenheim (at the western border of the Northern Franconian Alb, as marked in the map) exposes a $40 \mathrm{~m}$ profile of the Lower Jurassic ("Black Jurassic"). In some strata of the dark grey clay, representing organic-rich mudstone, fossils are encased in solid siderite concretions (Topographic map: upload.wikimedia.org/wikipedia/commons/d/da/Deutschland_topo.jpg; CC BY-SA 2.5. cf. Thiel and Hoppert, 2018)

\subsubsection{Microbial activity in fossilization}

Generally, physical and chemical factors rule over fossilization processes. Organic matter, at best stabilized by hard parts (bones, shells), must escape from immediate destruction and must get exposed to appropriate geochemical conditions in the sediment.

Most organisms do not become fossils due to microbial decay and physical damage. Physical processes dislocate intact and decaying organisms by water currents, freezing and thawing, 
burial and sediment movements. In addition, various conditions and environments may yield different types of preservation: Marine organisms in shallow water are the most likely to be preserved especially if fine-grained sediments bury them. In remineralization processes, sedimentary pore water in contact with carcasses allows dissolved minerals to seep through carcass hard parts and replace the biogenic minerals. In these processes, he two most abundant cements that produce mineralization of organic matter are calcium ions precipitating into calcite (the most stable form of calcium carbonate) and silica forming various silicates (e.g., Scholle and Ulmer-Scholle, 1978). Minerals containing copper, cobalt or, in particular, iron may contribute to permineralization of and add color to fossils (e.g., Dietrich et al., 2000; Mustoe and Acosta, 2016). Though microorganisms must not participate in these processes, available organic remains make microbial participation inevitable. Soon after an organism dies, microorganisms decompose the body by breaking down the biological macromolecules of all tissue constituents. However, microorganisms may play a very significant role in the reverse process, i.e. preservation by formation of minerals, preserving the shape of organic remains in certain environmental settings. Microbial activity plays an important part in the chemistry of calcite $\left(\mathrm{CaCO}_{3}\right)$, dolomite $\left(\mathrm{CaMgCO}_{3}\right)$ siderite $\left(\mathrm{FeCO}_{3}\right)$ and phosphates (Anbu et al., 2016). Among them, calcite is the main component of calcareous rocks and many fossils. Thus, fossilization depends on mineralization, which preserves the record of their existence.

Extensive geochemical studies of carbonate concretions have disclosed that the microbial degradation of organic matter plays an important role in minerals precipitation (Curtis et al., 1972; Irwin et al., 1977; Mozley and Burns, 1993; Raiswell and Fisher, 2000; Loyd et al., 2012; Loyd and Berelson, 2016). It is justified to consider, in particular, the involvement of bacterial sulfate reduction in formation of carbonate concretions. Generally, sulfate reduction - mostly in marine settings as sulfate-rich environments - is conducted along with either oxidation of 
higher organic compounds ( $C_{2}$ and larger) (Kamran et al., 2020) or with methane. Because these reactions increase alkalinity they lead to carbonate authigenesis (Coleman et al., 1993), which may be expressed in simplified ways as follows (Loyd and Berelson, 2016):

$\mathrm{SO}_{4}{ }^{2-}+2 \mathrm{CH}_{2} \mathrm{O} \Leftrightarrow \mathrm{H}_{2} \mathrm{~S}+2 \mathrm{HCO}_{3}^{-}$ organotrophic sulfate reduction (1)

$\mathrm{SO}_{4}{ }^{2-}+\mathrm{CH}_{4}+\mathrm{H}^{+} \Leftrightarrow \mathrm{H}_{2} \mathrm{~S}+\mathrm{HCO}_{3}{ }^{-}+\mathrm{H}_{2} \mathrm{O}$ methanotrophic sulfate reduction (2)

Hydrogen carbonate forms calcite and aragonite with calcium and magnesium ions, hydrogen sulfide forms iron sulfide minerals. However, in many sulfate reducing fossilization processes, concretion formation has not been observed. Gehling (1999) proposed a microbial death-mask model that emphasizes the role of sulfate reducers in precipitating iron sulfide minerals in another way. When thick microbial mats accumulate in the absence of effective metazoan grazing and bioturbation, sulfate is converted to hydrogen sulfide by sulfate reducing bacteria, and then this $\mathrm{H}_{2} \mathrm{~S}$ combined with iron in pore water forms pyrite, that is a death mask around a buried and decaying organism (Gehling, 1999; Jensen et al., 2005). This way of mineralization has been observed as "autolithification" of microorganisms (Wuttke, 1983) or as microbially induced soft tissue impregnation. The latter has been observed as formation of the phosphate mineral apatite, nucleating on particular sites of organic matter. In autolithification, the mineralized remains of bacterial cell walls may preserve the outline of soft tissues in, for instance, the famous mammals from Tertiary Lake Messel, Germany interestingly; these mineral remains are siderite (Wuttke, 1983, 1992). Recent studies have shown that concretions from Posidonia Shale Konservatlagerstätten may not only preserve biological macromolecules, but even soft tissue structure including cellular remains like outlines of cytoplasmic membranes (Melendez et al., 2013; Plet et al., 2017). Nuclei of $100 \mathrm{~nm}$ in size trace the shape of muscle fibers and cell membranes (Martill, 1990). 


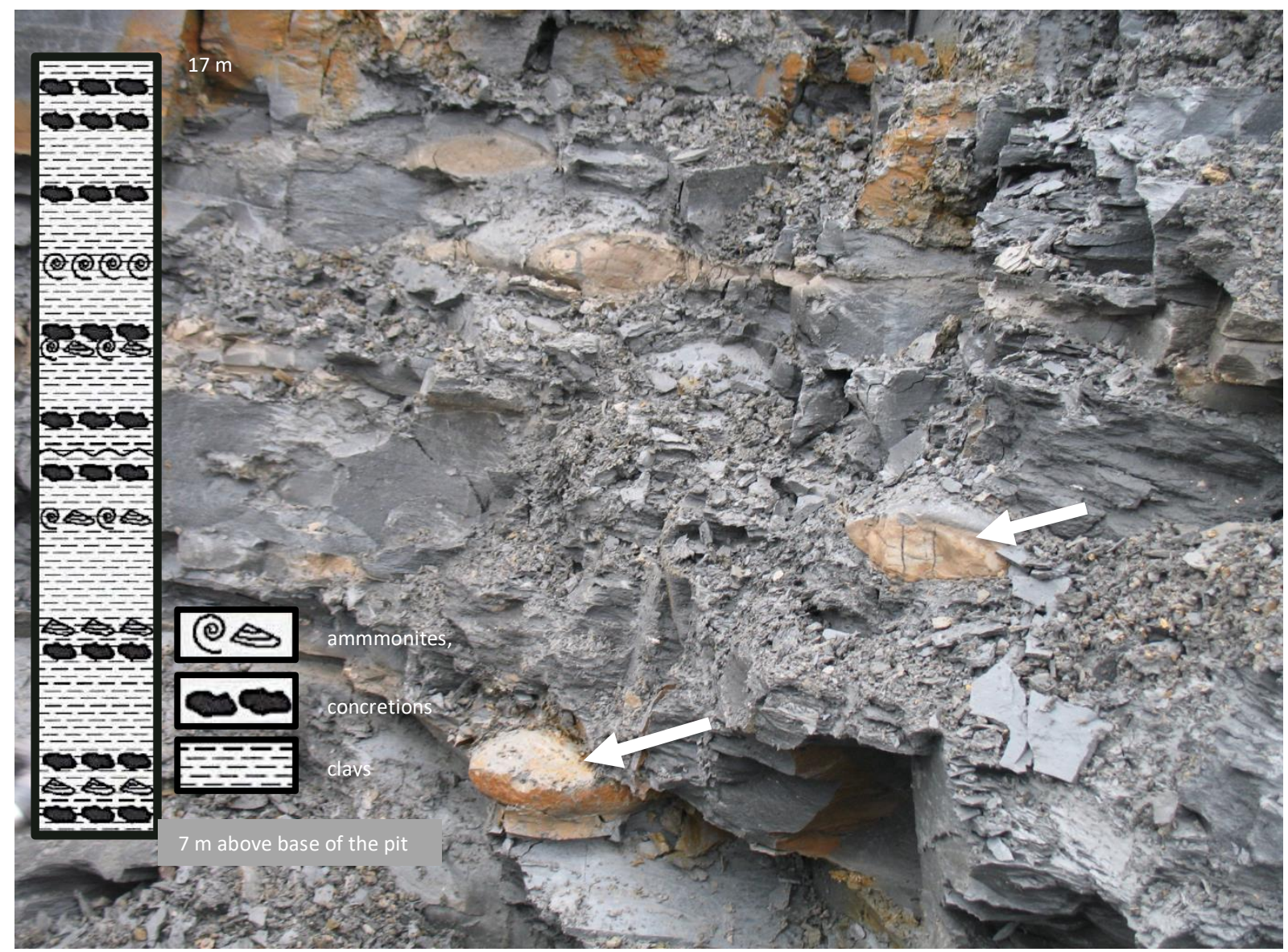

Fig. 2. Insight into concretion - rich layers of the Buttenheim clay pit (Franconian Alb; Germany). The left scheme shows some fossil-rich strata in a simplified way. Concretions occur in various layers. The large image shows brownish, putatively sideritic, lens-shaped concretions of approximately $20 \mathrm{~cm}$ (long diameter), marked by arrows (cf. Thiel and Hoppert, 2018).

\subsection{Extremely alkaline serpentinizing springs}

As stated in the first chapter, buffer capacity (alkalinity) and $\mathrm{pH}$ determines the equilibrium between precipitation and dissolution of carbonates. In extremely high $\mathrm{pH}$ water bodies, as long as calcium ions and carbon dioxide are present, carbonate precipitates will be formed rapidly. Extremely alkaline water bodes providing the dissolved ions are rare in nature, but alkaline springs associated with serpentinization are one exception. During serpentinization, the oxidation of iron ions in olivine and pyroxene with water results in formation of molecular 
hydrogen, methane and a variety of magnetite silicates (e.g., Sleep et al., 2004; Curtis, et al., 2013). An increase in $\mathrm{pH}$ is the result of olivine and pyroxene hydration, which releases $\mathrm{OH}^{-}$ and $\mathrm{Ca}^{2+}$ ions. In view of creating an extreme environment for microorganisms, active serpentinization has attracted attention in submarine settings such as in the Lost City hydrothermal field (part of the Atlantis massif, Mid-Atlantic Ocean Ridge), before terrestrial systems were also considered (Kelley et al., 2005; Schrenk et al., 2013; Monnin et al., 2014). The serpentinization-associated processes create rare and biologically changing conditions (limited resources of reduced substrates, high $\mathrm{pH}$ and limited electron acceptors) that are likely to limit the genetic and metabolic diversity of serpentinite-associated microbial community (Kelley et al., 2005; Brazelton et al., 2006, 2013). Hydrogen, methane and higher hydrocarbons derived from serpentinization may play important roles as primary energy sources for microbial processes, when other organic carbon sources and sunlight are unavailable. Therefore, it may be an important process for primordial life on earth and on other planetary bodies (Martin and Russell, 2007; Martin et al., 2008).

\subsection{Geochemistry in hyperalkaline springs of the Voltri Massif}

The Voltri Massif (VM) is a metamorphic ophiolite complex, located at the southernmost tip of the arc of the Western Alps and in direct neighborhood to the Apennine Mountains (Fig. 3). The VM is considered as a relic of the Jurassic Ligurian Tethys Ocean. It is composed of mafic and ultramafic rocks (metagabbro and metabasalt; peridotite and serpentinite) and argillaceous limestone, the latter was moderately tectonically and metamorphically overprinted (Cimmino et al., 1979; Messiga et al., 1991; Scambelluri, 1995; Federico, 2005; Malatesta, 2012, 2018; Capponi, 2016; Marescotti et al., 2019). The spring area of the Voltri ophiolite is located in the Ligurian Alps next to Genova and comprises about 20 peculiar high $\mathrm{pH}$ (11-12) water springs (Cipolli et al., 2004 Fig. 4). These hyperalkaline waters are very reductive, have low salinities, 
very low dissolved inorganic carbon (DIC) contents and temperature around $20{ }^{\circ} \mathrm{C}$ (Cipolli et al., 2004; Chavagnac et al., 2013b; Schwarzenbach et al., 2013). The spring fluids reflect the underlying biogeochemical processes in the subsurface.

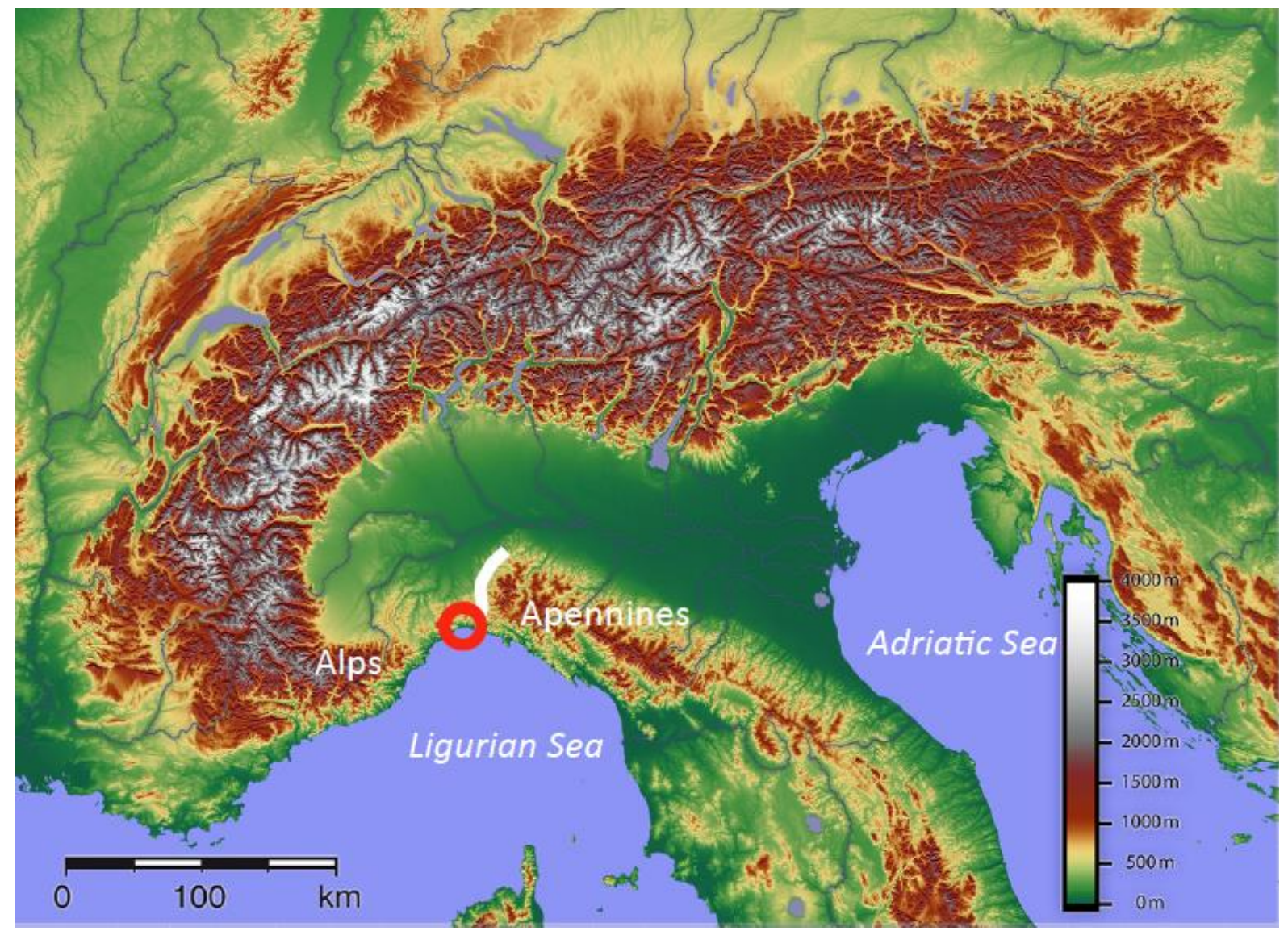

Fig. 3. Location of the alkaline spring area in the Voltri Massif (red circle), a mountain region with maximum elevations not much higher than $1000 \mathrm{~m}$, in direct neighborhood to the Apennine Mountains (borderline separates Alpine and Apennine geological units). Topographic map: commons.wikimedia.org/wiki/File:Alpenrelief_01.jpg; CC BY-SA 2.5 


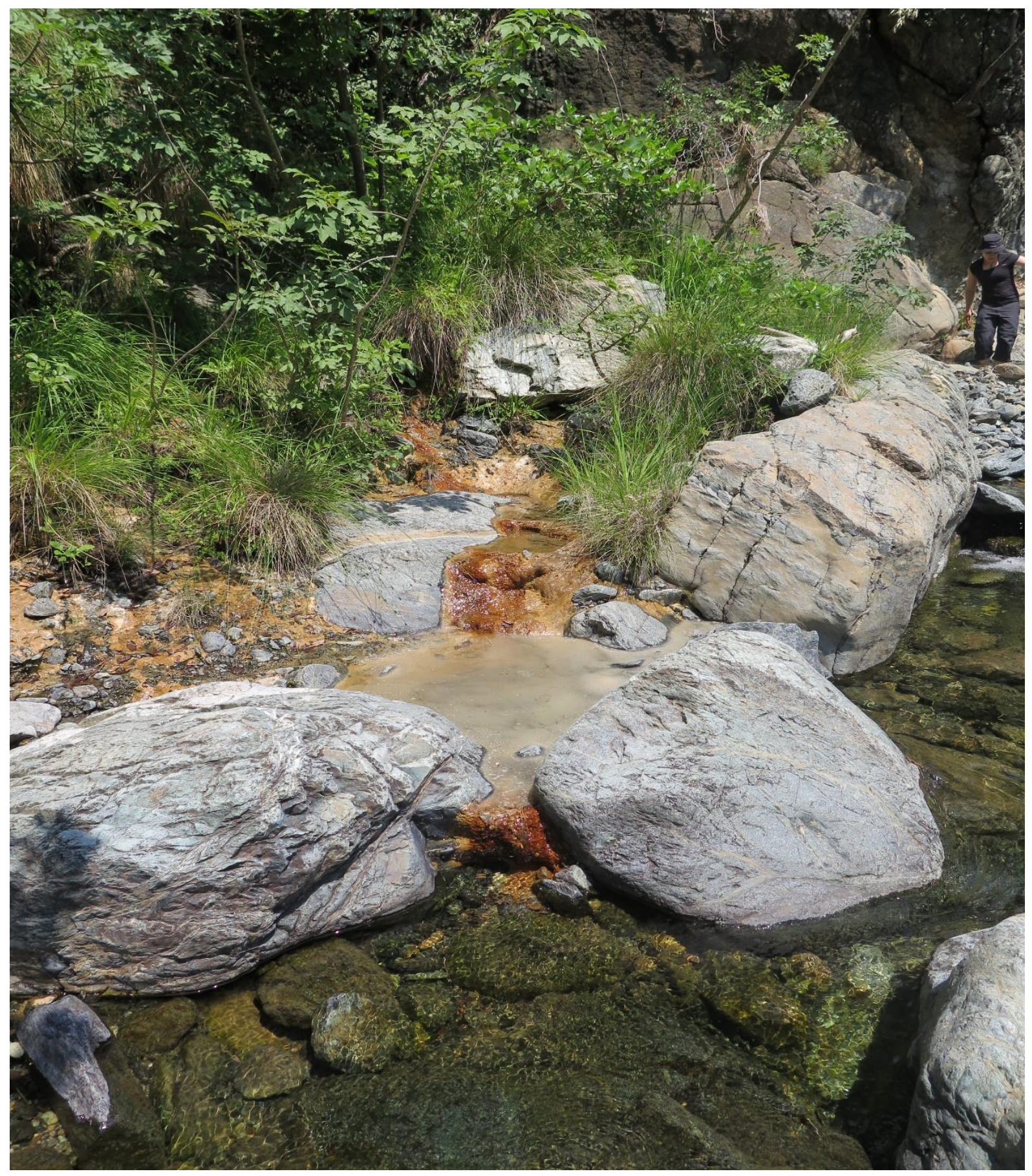

Fig. 4. A small pool formed by alkaline spring fluids in the Voltri Massif area (Torrente Lerone,

Arenzano). The deposition of carbonates (indicated by brownish appearance of staining iron oxides) are visible. The spring water discharges in the water of the Lerone River (foreground). 
Likely, the subsurface microbial communities in these environments depend on organic compounds and hydrogen gas released as byproducts of serpentinization. Some few studies have discussed methanotropic biological activity (Brazelton et al., 2011, 2017; Schrenk et al., 2013; Kohl et al., 2016). When water reaches serpentinized peridotites this ultimately results in alkaline solutions rich in calcium hydroxide. Considerable amounts of dissolved carbon dioxide finally ends up in precipitation of calcium carbonate (e.g., Barnes et al., 1967, 1972, 1978; Barnes and O’Neil, 1969; Neal and Stanger, 1983; Bruni et al., 2002; Cipolli et al., 2004; Boschetti and Toscani, 2008; Schwarzenbach et al., 2013; cf. Fig. 5). Previous carbon isotope analysis of dissoved inorganic carbon $\left(\delta^{13} \mathrm{C}\right.$-DIC) in Voltri sites account for closed-system carbonate precipitation (Schwarzenbach et al., 2013), i.e. with carbon dioxide not equilibrating with the atmospheric reservoir. Calcium $(\sim 1 \mathrm{mM})$ is the dominating precipitating cation (Cipolli et al., 2004; Chavagnac et al., 2013b). Some springs emit gas mainly composed of methane and nitrogen gas (Boulart, 2013). In spite of the just small amount of $\mathrm{H}_{2}$ in the gas phase, it may likely play an important role as energy driving force of the microbial communities inhabiting the deep biosphere serpentinite-hosted ecosystem (Quéméneur et al., 2015). 


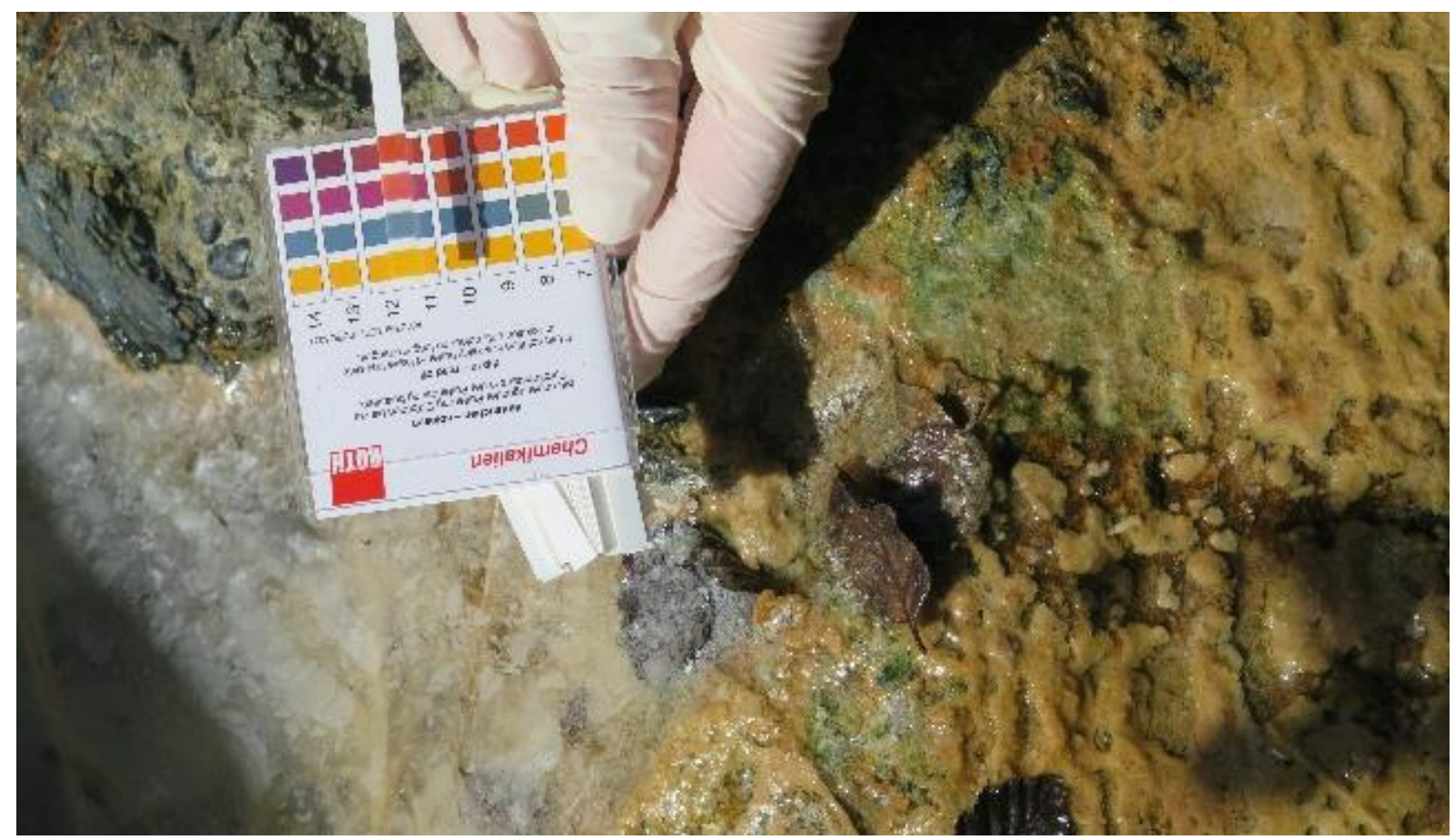

Fig. 5. Increased pH in fluids percolating across small calcite "terraces". Note the greenish appearance (photosynthetic biofilm) in the upper right part of the image.

However, despite of intense research on serpentinization in various aspects of geochemistry, geophysics and biology, carbonate mineralization with microbial community in alkaline fluids resulting from the serpentinization reaction has remained relatively poorly understood. At spring sites, small travertine terraces and other calcite buildups form rapidly, i.e. just after the water emerges from the outlet (Chavagnac et al., 2013b; Quéméneur et al., 2015; Kamran et al., 2021 [this study]). Calcite precipitation and crystal growth depends on various parameters such as the chemical composition of water $(\mathrm{pH}$, concentration of calcium ions and partial pressure in $\mathrm{CO}_{2}$, in particular), but is also influenced by thickness of the water film covering the surface, temperature, and the hydrodynamic conditions of flow (Buhmann and Dreybrodt, 1985). Because of the extreme $\mathrm{pH}$ values, prokaryotic microorganisms are the only colonizers in these systems, irrespective of the redox potential and of available energy sources. Feeding pressure 
by eukaryotic grazers does not challenge the community, but organisms have to adapt to rapid enclosure by calcite minerals.

The carbonate precipitating systems in this study cover two different aspects in the interaction between microbes and carbonate minerals: On the one hand, the investigations build upon previous taphonomic studies that have suggested that microbes play an important role in concretion formation. In addition to detailed microscopic analysis, this study also developed a microcosm approach, mimicking a lipid-rich environment in a dysoxic marine setting and highlights which microbial community ultimately contributed to the remarkable preservation of soft tissue through concretion formation. On the other hand, the study reveals the dominant microbes in an oxic, but extremely alkaline, carbonate precipitating environment, dominated by a photosynthetic microbial community. In this way, it spans over a wide range of environmental conditions, supporting microbe associated carbonate mineral formation. 


\subsection{References}

Allison, P.A. (1988) The role of anoxia in the decay and mineralization of proteinaceous macro-fossils. Paleobiology 14: 139-154.

Allison, P.A. (1988a) Konservat-Lagerstaetten; cause and classification. Paleobiology 14: 331-344.

Anbu, P., Kang, C. H., Shin, Y. J., So, J. S. (2016) Formations of calcium carbonate minerals by bacteria and its multiple applications. Springer Plus 5: 250.

Barnes, I., LaMarceh, V.C., Himmelberg, G. (1967) Geochemical evidence of present-day serpentinization. Science 156: 830-832.

Barnes, I., O'Neil, J.R., (1969) Relationship between fluids in some fresh alpine-type ultramafics and possible modern serpentinization, Western United States. Geological Society of America Bulletin 80: 1947-1960.

Barnes, I., O'Neil, J.R., Trescases, J.J. (1978) Present day serpentinization in New Caledonia, Oman and Yugoslavia. Geochimica et Cosmochimica Acta 42: 144-145.

Barnes, I., Sheppard, R.A., Gude, A.J., Rapp, J.B., O'Neil, J.R. (1972) Metamorphic assemblages and direction of flow of metamorphic fluids in four instances of serpentinization. Contributions to Mineralogy and Petrology 35: 263-276.

Berner, R. A. (1968) Calcium carbonate concretions formed by the decomposition of organic matter. Science 159: 195-197.

Boles, J. R., Landis, C. A., Dale, P. (1985) The Moeraki Boulders; anatomy of some septarian concretions. Journal of Sedimentary Research 55: 398-406.

Boschetti, T., Toscani, L. (2008) Springs and streams of the Taro-Ceno valleys (northern Apennine, Italy): Reaction path modeling of waters interacting with serpentinized ultramafic rocks. Chemical Geology 257: 76-91.

Bottjer, D.J., Etter, W., Hagadorn, J.W., Tang, C.M. (2002) Fossil-Lagerstätten: Jewels of the Fossil Record. In Exceptional Fossil Preservation: A Unique View on the Evolution of Marine Life (eds. Bottjer, D., Etter, W). Columbia University Press: New York, USA. pp. $1-10$.

Boulart, C., Chavagnac, V., Monnin, C., Delacour A., Ceuleneer, G., Hoareau, G. (2013) Differences in gas venting from ultramafic-hosted warm springs: the example of Oman and Voltri ophiolites. Ofioliti 38: 142-156. 
Brazelton, W. J., Morrill, P. L., Szponar, N., Schrenk, M. O. (2013) Bacterial communities associated with subsurface geochemical processes in continental serpentinite springs. Applied and Environmental Microbiology 79: 3906-3916.

Brazelton, W.J., Schrenk, M.O., Kelley, D.S., Baross, J.A. (2006) Methane and sulfurmetabolizing microbial communities dominate the Lost City hydrothermal field ecosystem. Applied and Environmental Microbiology 72: 6257-6270.

Brazelton, W.J., Thornton, C.N., Hyer, A., Twing, K.I., Longino,A.A., Lang,S.Q., Lilley, M.D., Früh-Green, G.L. Schrenk, M.O. (2017) Metagenomic identification of active methanogens and methanotrophs in serpentinite springs of the Voltri Massif, Italy. PeerJ 5: e2945.

Brazelton,W. J., Mehta, M. P., Kelley, D. S., and Baross, J. A. (2011) Physiological differentiation within a single-species biofilm fueled by serpentinization. mBio 2: e0012711.

Briggs, D. E. (1995) Experimental taphonomy. Palaios 539-550.

Briggs, D. E. (2003) The role of decay and mineralization in the preservation of soft-bodied fossils. Annual Review of Earth and Planetary Sciences 31: 275-301.

Briggs, D.E.G., Kear, A.J. (1994) Decay and mineralization of shrimps. Palaios 9: 431-456.

Briggs, D.E.G., Clark, N.D.L., Clarkson, E.N.K., Clarkson (1991) The Granton "shrimpbed', Edinburgh-a Lower Carboniferous Konservat-Lagerstatte. Earth and Environmental Science Transactions of The Royal Society of Edinburgh 82: 65-85.

Bruni, J., Canepa, M., Chiodini, G., Cioni, R., Cipolli, F., Longinelli, A., Marini, L., Ottonello, G., Vetuschi Zuccolini, M. (2002) Irreversible water-rock mass transfer accompanying the generation of the neutral, $\mathrm{Mg}-\mathrm{HCO}_{3}$ and high-pH, $\mathrm{Ca}-\mathrm{OH}$ spring waters of the Genova province, Italy. Applied Geochemistry 17: 455-474.

Buhman, D., Dreybrodt, W. (1985) The kinetics of calcite dissolution and precipitation in geologically relevant situations of karst areas. 1. Open system. Chemical Geology. 48: 189211.

Canfield, D. E., Thamdrup, B., Hansen, J. W. (1993) The anaerobic degradation of organic matter in Danish coastal sediments: iron reduction, manganese reduction, and sulfate reduction. Geochimica et Cosmochimica Acta 57: 3867-3883.

Capponi, G., Crispini, L., Federico, L., Malatesta, C. (2016) Geology of the Eastern Ligurian Alps: A review of the tectonic units. Ital. Journal of Geosciences 135: 157-169. 
Chavagnac, V., Monnin, C., Ceuleneer, G., Boulart, C., Hoareau, G. (2013b) Characterization of hyperalkaline fluids produced by low temperature serpentinization of mantle peridotites in the Oman and Ligurian ophiolites. Geochemistry, Geophysics, Geosystems 14: 2496-2522.

Cimmino, F., Messiga, B., Piccardo, G.B. (1979) Ti-clinohumite-bearing assemblages within antigoritic serpentinites of the Voltri Massif (Western Liguria): Inferences on the geodynamic evolution of piemontese ultramafic sections. Ofioliti 4: 97-120.

Cipolli, F., Gambardella, B., Marini, L., Ottonello, G., Vetuschi Zuccolini, M. (2004) Geochemistry of high-pH waters from serpentinites of the Gruppo di Voltri (Genova, Italy) and reaction path modeling of $\mathrm{CO}_{2}$ sequestration in serpentinite aquifers. Applied Geochemistry 19: 787-802.

Clarke, J.D., Stoker, C.R. (2011) Concretions in exhumed and inverted channels near Hanksville Utah: implications for Mars. International Journal of Astrobiology 10: 161-175.

ClarkRidi, M.S. (2020) Molecular mechanisms of biomineralization in marine invertebrates. Journal of Experimental Biology 223: jeb206961.

Clements, T., Purnell, M., Gabbott, S. (2019) The Mazon Creek Lagerstätte: a diverse late Paleozoic ecosystem entombed within siderite concretions. Journal of the Geological Society 176: 1-11.

Coleman, M. L. (1993) Microbial processes: Controls on the shape and composition of carbonate concretions. Marine Geology 113: 127-140.

Curtis, A.C., Wheat, C.G., Fryer, P., Moyer, C.L. (2013) Mariana Forearc serpentinite mud volcanoes harbor novel communities of extremophilic archaea. Geomicrobiology Journal 30: $430-441$.

Curtis, C. D., Petrowski, C., Oertel, G. (1972) Stable carbon isotope ratios within carbonate concretions: a clue to place and time of formation. Nature 235: 98-100.

Curtis, C.D., M.L. Coleman, L.G. Love. (1986) Pore water evolution during sediment burial from isotopic and mineral chemistry of calcite, dolomite and siderite concretions. Geochimica et Cosmochimica Acta 50: 2321-2334.

Dale, A., John, C. M., Mozley, P. S., Smalley, P., Muggeridge, A. H. (2014) Time-capsule concretions: Unlocking burial diagenetic processes in the Manco Shale using carbonate clumped isotopes. Earth and Planetary Science Letters 394: 30-37. 
Desrochers, A., Al-Aasm, I.S. (1993) The formation of septarian concretions in Queen Charlotte Islands, BC: evidence for microbially and hydrothermally mediated reactions at shallow burial depth. Journal of Sedimentary Research 63: 282-294.

Dietrich, D., Frosch, G., Rößler, R., Marx, G. (2000) Analytical x-ray microscopy on Psaronius sp.-a contribution to permineralization process studies. Microchimica Acta 133: 279-283.

Dong, J., Zhang, S.H., Jiang, G.Q., Li, H.Y., Gao, R. (2013) Greigite from carbonate concretions of the Ediacaran Doushantuo Formation in South China and its environmental implications. Precambrian Research 225: 77-85.

Dupraz, C., Visscher, P.T. (2006) Microbial lithification in marine stromatolites and hypersaline mats. Trends in Microbiology 13: 429-438.

El Albanni, A., Vachard, D., Kuhnt, W., Thurow, J. (2001) The role of diagenetic carbonate concretions in the preservation of the original sedimentary record. Sedimentology 48: 875886.

Federico, L., Capponi, G., Crispini, L., Scambelluri, M., Villa, I.M. (2005) ${ }^{39} \mathrm{Ar} /{ }^{40} \mathrm{Ar}$ dating of high-pressure rocks from the Ligurian Alps: Evidence for a continuous subductionexhumation cycle. Earth and Planetary Science Letters 240: 668-680.

Feistner, K. (1989) Petrographic examination and reinterpretation of concretionary carbonate horizons from the Kimmeridge Clay, Dorset. Journal of the Geological Society 146: $345-350$.

Fisher, Q., Raiswell, R., Marshall, J. (1998) Siderite concretions from nonmarine shales (Westphalian A) of the Pennines, England: controls on their growth and composition. Journal of Sedimentary Research 68: 1034-1045.

Gaines, R.R., Vorhies, J.S. (2016) Growth mechanisms and geochemistry of carbonate concretions from the Cambrian Wheeler Formation (Utah, USA). Sedimentology 63: 662698.

Gaines, R.R., Briggs, D.E., Orr, P.J., Van Roy, P. (2012a) Preservation of giant anomalocaridids in silica-chlorite concretions from the Early Ordovician of Morocco. Palaios 27: 317-325.

Gehling, J.G. (1999) Microbial mats in terminal Proterozoic siliciclastics: Ediacaran death masks. Palaios 14: 40-57.

Gould, S. J. (1990) Wonderful life: the Burgess Shale and the nature of history. WW Norton \& Company, New York. 
Grice, K., Holman, A.I., Plet, C., Tripp, M. (2019) Fossilised biomolecules and biomarkers in carbonate concretions from Konservat-Lagerstätten. Minerals 9: 158.

Haley, B.A., Klinkhammer, G.P., McManus. J (2004) Rare earth elements in pore waters of marine sediments. Geochimica et Cosmochimica Acta 68: 1265-1279.

Hart, B., Longstaffe, F., Plint, A. (1992) Evidence for relative sea level change from isotopic and elemental composition of siderite in the Cardium Formation, Rocky Mountain Foothills. Bulletin of Cananadian Petroleum Geology 40: 52-59.

Hendry, J.P., Pearson, M.J., Trewin, N.H., Fallick, A.E. (2006) Jurassic septarian concretions from NW Scotland record interdependent bacterial, physical and chemical processes of marine mudrock diagenesis. Sedimentology 53: 537-565.

Hennessy, J., Knauth, L.P. (1985) Isotopic variations in dolomite concretions from the Monterey Formation, California. Journal of Sedimentary Research 55: 120-130.

Irwin, H., Curtis, C., Coleman, M. (1977) Isotopic evidence for source of diagenetic carbonates formed during burial of organic-rich sediments. Nature 269: 209-213.

Jensen, S., Droser, M. L., Gehling, J. G. (2005) Trace fossil preservation and the early evolution of animals. Palaeogeography, Palaeoclimatology, Palaeoecology, 220: 19-29.

Kamran, A., Schneider, D., Roddatis, V., Thiel, V., Hoppert, M. (2020) Formation of siderite in microbial microcosms derived from a marine sediment. Geomicrobiology Journal 37: 475-485.

Kamran, A., Sauter, K., Reimer, A., Wacker, T., Reitner, J., Hoppert, M. (2021) Cyanobacterial mats in calcite-precipitating serpentinite-hosted alkaline springs of the Voltri Massif, Italy. Microorganisms 9: 62.

Kelley, D.S., Karson, J.A., Früh-Green, G.L. (2005) A serpentinite-hosted ecosystem: the Lost City hydrothermal field. Science 307: 1428-1434.

Kiriakoulakis, K., Marshall, J. Wolff, G. (2000) Biomarkers in a Lower Jurassic concretion from Dorset (UK). Journal of the Geological Society 157: 207-220.

Kohl, L., Cumming, E., Cox, A., Rietze, A., Morrissey, L., Lang, S. Q., Richter, A., Suzuki, S., Nealson, K.H., Morrill, P. L. (2016) Exploring the metabolic potential of microbial communities in ultra-basic, reducing springs at The Cedars, CA, USA: experimental evidence of microbial methanogenesis and heterotrophic acetogenesis. Journal of Geophysical Research: Biogeosciences 121: 1203-1220. 
Loyd, S.J., Berelson, W.M. (2016) The modern record of "concretionary" carbonate: Reassessing a discrepancy between modern sediments and the geologic record. Chemical Geology 420: 77-87.

Loyd, S.J., Corsetti, F.A., Eiler, J.M., Tripati, A.K. (2012) Determining the diagenetic conditions of concretion formation: assessing temperatures and pore waters using clumped isotopes. Journal of Sedimentary Research 82: 1006-1016.

Loyd, S.J., Dickson, J., Boles, J.R., Tripati, A.K. (2014) Clumped-isotope constraints on cement paragenesis in septarian concretions. Journal of Sedimentary Research 84: 1170118.

Loyd, S.J., Berelson, W.M., Lyons, T.W., Hammond, D.E., Tripati, A.K., Eiler, J.M., Corsetti. F.A. (2012) Formation mechanisms of carbonate concretions of the Monterey Formation: Analyses of clumped isotopes, iron, sulfur and carbon. Mineralogical Magazine 76: $2036-2036$.

Malatesta, C., Crispini, L., Federico, L., Capponi, G., Scambelluri, M. (2012) The exhumation of high pressure ophiolites (Voltri Massif, Western Alps): Insights from structural and petrologic data on metagabbro bodies. Tectonophysics, 568: 102-123.

Malatesta, C., Federico, L., Crispini, L., Capponi, G. (2018) Fluid-controlled deformation in blueschist-facies conditions: plastic vs brittle behaviour in a brecciated mylonite (Voltri Massif, Western Alps, Italy). Geological Magazine 155: 335-355.

Marescotti, P., Comodi, P., Crispini, L., Gigli, L., Zucchini, A., Fornasaro, S. (2019) Potentially toxic elements in ultramafic soils: A study from metamorphic ophiolites of the Voltri Massif (Western Alps, Italy). Minerals 9: 502.

Martill, D.M. (1990) Macromolecular resolution of fossilized muscle tissue from an elomorph fish. Nature 346: 171-72.

Martin, W., and Russell, M.J. (2007) On the origin of biochemistry at an alkaline hydrothermal vent: Philosophical Transactions of the Royal Society of London. Series B. Biological Sciences 362: 1887-1926.

Martin, W., Baross, J., Kelley, D., Russell, M. (2008) Hydrothermal vents and the origin of life: Nature Reviews Microbiology 6: 805-814.

McCoy, V. E. (2014) Concretions as agents of soft-tissue preservation: a review. The Paleontological Society Papers 20: 147-162.

McCoy, V.E., Young, R.T., Briggs, D.E. (2015a) Factors controlling exceptional preservation in concretions. Palaios 30: 272-280. 
Melendez, I., Grice, K., Trinajstic, K., Ladjavardi, M., Greenwood, P., Thompson, K. (2013) Biomarkers reveal the role of photic zone euxinia in exceptional fossil preservation: An organic geochemical perspective. Geology 41: 123-126.

Messiga, B., Scambelluri, M. (1991) Retrograde P-T-t path for the Voltri Massif eclogites (Ligurian Alps, Italy): Some tectonic implications. Journal of Metamorphic Geology 9: 93109.

Monnin, C., Chavagnac, V., Boulart, C., Payri, C., Ménez, B., Gérard, M., Gérard, E., Quéméneur, M., Erauso, G., Postec, A., Dombrowski, L., Pelletier, B. (2014) Fluid chemistry of the low temperature hyperalkaline hydrothermal system of the Prony Bay (New Caledonia). Biogeosciences 11: 5687-5706.

Monteiro, F. M., Bach, L. T., Brownlee, C., Bown, P., Rickaby, R. E., Poulton, A. J., Tyrrell, T., Beaufort, L., Dutkiewicz, S., Gibbs, S., Gutowska, M. A., Lee, R., Riebesell, U., Young, J., Ridgwell, A. (2016) Why marine phytoplankton calcify. Science advances 2: e1501822.

Morris, S. C. (1986) The community structure of the Middle Cambrian phyllopod bed (Burgess Shale). Palaeontology 29: 423-467.

Mozley, P.S. (1989) Complex compositional zonation in concretionary siderite: implications for geochemical studies. Journal of Sedimentary Research 59: 815-818.

Mozley, P.S. (1996) The internal structure of carbonate concretions in mudrocks: a critical evaluation of the conventional concentric model of concretion growth. Sedimentary Geology 103: 85-91.

Mozley, P.S., Burns, S.J. (1993) Oxygen and carbon isotopic composition of marine carbonate concretions: an overview. Journal of Sedimentary Research 63: 73-83.

Mustoe, G., Acosta, M. (2016) Origin of petrified wood color. Geosciences 6: 25.

Neal, C., Stanger, G. (1983) Hydrogen generation from mantle source rocks in Oman. Earth and Planetary Science Letters 66: 315-320.

Parry, L.A., Smithwick, F., Nordén, K.K., Saitta, E.T., Lozano-Fernandez, J., Tanner, A.R., Caron, J.-B., Edgecombe, G.D., Briggs, D.E.G., Vinther, J. (2018) Soft-bodied fossils are not simply rotten carcasses - toward a holistic understanding of exceptional fossil preservation. BioEssays 40: 1700167.

Pearson, M.J., Nelson, C.S. (2005) Organic geochemistry and stable isotope composition of New Zealand carbonate concretions and calcite fracture fills. New Zealand Journal of Geology and Geophysics 48: 395-414. 
Plet, C., Grice, K., Pagès, A., Ruebsam, W., Coolen, M.J.L., Schwark, L. (2016) Microbially-mediated fossil-bearing carbonate concretions and their significance for palaeoenvironmental reconstructions: A multi-proxy organic and inorganic geochemical appraisal. Chemical Geology 426: 95-108.

Plet, C., Grice, K., Pagès, A., Verrall, M., Coolen, M.J.L., Ruebsam, W., Rickard, W.D.A., Schwark, L. (2017) Palaeobiology of red and white blood cell-like structures, collagen and cholesterol in an ichthyosaur bone. Scientific Reports 7: 1-10.

Potter, S.L., Chan, M.A., Petersen, E.U., Dyar, M.D., Sklute, E. (2011) Characterization of Navajo Sandstone concretions: Mars comparison and criteria for distinguishing diagenetic origins. Earth and Planetary Science Letters 301: 444-456.

Quéméneur, M., Palvadeau, A., Postec, A., Monnin, C., Chavagnac, V., Ollivier, B., Erauso, G. (2015) Endolithic microbial communities in carbonate precipitates from serpentinite-hosted hyperalkaline springs of the Voltri Massif (Ligurian Alps, Northern Italy). Environmental Science and Pollution Research 22: 13613-13624.

Raiswell, R. (1988) Chemical model for the origin of minor limestone-shale cycles by anaerobic methane oxidation. Geology 16: 641-644.

Raiswell, R., Fisher, Q. (2000) Mudrock-hosted carbonate concretions: a review of growth mechanisms and their influence on chemical and isotopic composition. Journal of the Geological Society 157: 239-251.

Ridgwell, E., Zeebe, R.E. (2005) The role of the global carbonate cycle in the regulation and evolution of the Earth system. Earth and Planetary Science Letters 234: 299-315.

Riding, R. (1978) Algal and bacterial carbonate sediments. In: Sedimentology. Encyclopedia of Earth Science. Springer, Berlin.

Röhl, H.J., Schmid-Röhl, A., Oschmann, W., Frimmel, A., Schwark, L. (2001) The Posidonia Shale (Lower Toarcian) of SW-Germany: An oxygen-depleted ecosystem controlled by sea level and palaeoclimate. Palaeogeography, Palaeoclimatology, Palaeoecology 165: 27-52.

Scambelluri, M., Müntener, O., Hermann, J., Piccardo, G.B., Trommsdor, V. (1995) Subduction of water into the mantle: History of an Alpine peridotite. Geology 23: 459-462.

Scholle P.A., Ulmer-Scholle D. (1978) Cements and cementation. In: Sedimentology. Encyclopedia of Earth Science. Springer, Berlin.

Schrenk, M.O., Brazelton, W.J., Lang, S.Q. (2013) Serpentinization, carbon, and deep life. Reviews in Mineralogy and Geochemistry 75: 575-606. 
Schwarzenbach, E.M., Lang, S.Q., Früh-Green, G.L., Lilley, M.D., Bernasconi, S.M., Méhay, S. (2013) Sources and cycling of carbon in continental, serpentinite-hosted alkaline springs in the Voltri Massif, Italy. Lithos 177: 226-244.

Seilacher, A. (1970) Begriff und Bedeutung der Fossil-Lagerstätten. Neues Jahrbuch für Geologie und Palöntologie Monatshefte pp. 34-39.

Sellés-Martínez, J. (1996) Concretion morphology, classification and genesis. EarthScience Reviews 41: 177-210.

Sleep, N. H., Meibom, A., Fridriksson, T., Coleman, R. G., Bird, D. K. (2004) H2-rich fluids from serpentinization: geochemical and biotic implications. Proceedings of the National Academy of Sciences of the United States of America 101: 12818-12823.

Spitzer, S., Brinkmann, N., Reimer, A., Ionescu, D., Friedl, T., de Beer, D., Arp, G. (2015) Effect of variable $\mathrm{pCO}_{2}$ on $\mathrm{Ca}^{2+}$ removal and potential calcification of cyanobacterial biofilms - an experimental microsensor study. Geomicrobiology Journal, 32: 304-315.

Squyres, S.W., Grotzinger, J., Arvidson, R., Bell, J., Calvin, W., Christensen, P., Clark, B., Crisp, J., Farrand, W., Herkenhoff, K.E. (2004) In situ evidence for an ancient aqueous environment at Meridiani Planum, Mars. Science 306: 1709-1714.

Stack, K., Grotzinger, J., Kah, L., Schmidt, M., Mangold, N., Edgett, K., Sumner, D., Siebach, K., Nachon, M., Lee, R. (2014) Diagenetic origin of nodules in the Sheepbed member, Yellowknife Bay formation, Gale crater, Mars. Journal of Geophysical Research: Planets 119: 1637-1664.

Sues, H. D., Munk, W. (1996) A remarkable assemblage of terrestrial tetrapods from the Zechstein (Upper Permian: Tatarian) near Korbach (northwestern Hesse). Paläontologische Zeitschrift 70: 213-223.

Thamdrup, B., Canfield, D.E. (1996) Pathways of carbon oxidation in continental margin sediments off central Chile. Limnology and Oceanography 41: 1629-1650.

Thiel, V., Hoppert M. (2018) Fatty acids and other biomarkers in two Early Jurassic concretions and their immediate host rocks (Lias $\delta$, Buttenheim clay pit, Bavaria, Germany). Organic Geochemistry 120: 42-55.

Vorhies, J.S. and Gaines, R.R. (2009) Microbial dissolution of clay minerals as a source of iron and silica in marine sediments. Nature Geoscience 2: 221-225.

Wuttke, M. (1983) Weichteil-Erhaltungn durch lithifizierte Mikroorganismen bei mitteleozänen Vertebraten aus den Ölschiefern der 'Grube Messel' bei Darmstadt. Senckenbergiana lethaea 64: 509-527. 
Wuttke, M. (1992) Conservation-dissolution transformation. On the behaviour of biogenic materials during fossilization. In Messel - An Insight into the History of Life and of the Earth (eds Schaal, S., Ziegler, W.). Clarendon, Oxford, pp. 265-275.

Yoshida, H., Yamamoto, K., Minami, M. Katsuta, N., Sin-ichi, S., Metcalfe, R. (2018) Generalized conditions of spherical carbonate concretion formation around decaying organic matter in early diagenesis. Scientific Reports 8: 6308.

Zapalski, M. K., and Clarkson, E. N. (2015) Enigmatic fossils from the Lower Carboniferous shrimp bed, Granton, Scotland. Plos one 10: e0144220. 


\section{Formation of siderite in microbial microcosms derived from a marine sediment}

Aysha Kamran ${ }^{1}$, Dominik Schneider ${ }^{1}$, Vladimir Roddatis ${ }^{3}$, Volker Thiel ${ }^{2}$, Michael Hoppert ${ }^{1}$

Published in

Geomicrobiology Journal (2020) 37:5, 475-485, DOI: 10.1080/01490451.2020.1725186

${ }^{1}$ Institute of Microbiology and Genetics, Georg-August-University Göttingen, Grisebachstraße 8, 37077 Göttingen, Germany

${ }^{2}$ Göttingen Centre of Geosciences, Georg-August-University Göttingen, Goldschmidtstr. 3, 37077 Göttingen, Germany

${ }^{3}$ Institute of Materials Physics, Georg-August-University Göttingen, Friedrich-Hund-Platz 1, 37077 Göttingen, Germany

Corresponding author: mhopper@gwdg.de, Phone: +49-551-3933832

\section{Author contribution to the work:}

$\mathrm{MH}, \mathrm{VT}$ and AK designed the study. AK performed the microcosm experiments, transmission electron microscopy, data analysis, interpreted the results and wrote the manuscript. DS performed the bioinformatics analysis for the sequenced data. VR helped in the scanning transmission electron microscopy analysis and its interpretation. $\mathrm{MH}$ provided reagents and lab facility, work collaboration, interpreted the results and corrected the manuscript. VT provided lab facility for MS analysis and critically reviewed the manuscript. 


\title{
Geomicrobiology Journal
}

ISSN: 0149-0451 (Print) 1521-0529 (Online) Journal homepage: https://www.tandfonline.com/loi/ugmb20

\section{Formation of Siderite in Microbial Microcosms Derived from a Marine Sediment}

\author{
Aysha Kamran, Dominik Schneider, Vladimir Roddatis, Volker Thiel \& \\ Michael Hoppert
}

To cite this article: Aysha Kamran, Dominik Schneider, Vladimir Roddatis, Volker Thiel \& Michael Hoppert (2020) Formation of Siderite in Microbial Microcosms Derived from a Marine Sediment, Geomicrobiology Journal, 37:5, 475-485, DOI: 10.1080/01490451.2020.1725186

To link to this article: https://doi.org/10.1080/01490451.2020.1725186

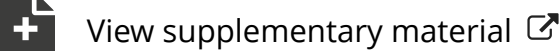

Published online: 19 Feb 2020.

6 Submit your article to this journal $\pi$

III Article views: 140

View related articles $\widetilde{\nearrow}$

View Crossmark data ¿ 


\title{
Formation of Siderite in Microbial Microcosms Derived from a Marine Sediment
}

\author{
Aysha Kamran ${ }^{\mathrm{a}}$, Dominik Schneider ${ }^{\mathrm{a}}$, Vladimir Roddatis ${ }^{\mathrm{b} *}$, Volker Thiel $^{\mathrm{c}}$, and Michael Hoppert ${ }^{\mathrm{a}}$ \\ ${ }^{a}$ Institute of Microbiology and Genetics, University of Goettingen, Goettingen, Germany; ${ }^{b}$ Institute of Materials Physics, University of \\ Göttingen, Goettingen, Germany; 'Geobiology, Geoscience Centre, University of Goettingen, Goettingen, Germany
}

\begin{abstract}
Exceptionally well-preserved fossils are frequently encased by carbonate concretions. The initial steps of their formation in marine and freshwater sediments are induced by microbial activity. The role of the involved microbial communities, however, is not well understood. In this study, siderite $\left(\mathrm{FeCO}_{3}\right)$ formation in microbial microcosms is observed, with various fatty acyl compounds (lipids, surfactants) as substrates and Wadden Sea sediment samples as inocula. In actively growing microcosms, sulfate-reducing bacteria (the genus Desulfofrigus in particular) dominate the microbial community and submicroscopic siderite precipitates on bacterial cell surfaces were identified. We suggest that these biologically induced mineralization processes may, in the natural environment, initiate the formation of large concretions under suboxic conditions in coastal sediments.
\end{abstract}

ARTICLE HISTORY

Received 22 April 2019

Accepted 30 January 2020

\section{KEYWORDS}

Fossilization; sulfate reduction; microbial community; siderite; biomineral; community structure; molecular ecology; sulfate reducing bacteria

\section{Introduction}

The formation of fossils from living matter is necessarily linked to the degradation of organic matter. The process of decay, mainly driven by microbial activity, promotes generation of different kinds of mineral precipitates being crucial in the taphonomic process. Under ideal conditions, these minerals may encase and finally replace the organic structures, sometimes even resulting in the preservation of softtissue structures (e.g., Briggs 2003).

Because of the generally rapid degradation of animal tissue, the initial process of mineral formation is fast and easily observable, but further diagenetic alterations may be longlasting and have not yet been directly observed (Parry et al. 2018; Sagemann et al. 1999). Regularly, concretions consisting of calcium carbonates and various iron, phosphate, and sulfur minerals are involved in fossil formation. Pyrite $\left(\mathrm{FeS}_{2}\right)$, the primary mineral product of bacterial sulfate reduction in anoxic sediments, is known to encase exceptionally preserved fossils (e.g., Tibbs et al. 2003). In a set of model experiments, Darroch et al. (2012) suggested that the development of a pyrite 'death mask' (mold) around a carcass through precipitation of iron sulfide and clay minerals is dependent on the exclusion of oxygen. Further, Gibson et al. (2018) explained in a 'death mask' model that pyrite will form early within the taphonomic window, thus preserving soft bodied organisms. Siderite $\left(\mathrm{FeCO}_{3}\right)$ is another iron mineral associated with bacterial sulfate reduction (Coleman et al. 1993). The formation of either pyrite or siderite in sediments may be mainly influenced by pore water sulfate/sulfide and $\mathrm{Fe}^{2+}$-concentration (Postma 1977, 1982).
In the course of the Phanerozoic, fossil-preserving siderite concretions occurred frequently in specific strata. For instance, in Lower Jurassic (Lias delta) strata of the Buttenheim clay pit (Bavaria, Germany), siderite-rich concretions encase particularly well-preserved marine invertebrates retaining their initial aragonitic shell mineralogy (Keupp and Schweigert 2008; Thiel and Hoppert 2018). Formation of siderite concretions also promoted exceptional preservation of soft tissue in the most important Upper Carboniferous (Pennsylvanian) fossil Lagerstätte Mazon Creek (Ill., USA; Cotroneo et al. 2016; Clements et al. 2019). Siderite concretions were also described from Upper Carboniferous non-marine shales of the Pennines (NEngland; Fisher et al. 1998). Other examples include the Lower Carboniferous Wardie Shale (Scotland) where concretions were formed in brackish-water basin under sulfatereducing conditions (Bojanowski and Clarkson 2012) or the Upper Cretaceous Gammon Shale (northern Great Plains; Gautier 1982).

The formation of siderite concretions in contemporary marine sediments has been rarely described until now (e.g., Pye et al. 1990), putatively because of considerable differences in sea water ion concentrations (hence pore water chemistry), sea levels and extensions of continental shelfs, or climate conditions. Whereas their formation process is still enigmatic, the presence of fossils inside siderite concretions suggests that initial mineralization was associated with the decomposition of organic matter, fueling sulfate reduction and other metabolic processes. Our previous findings indicated a major role of lipids, released by the decaying carcass 
or from other sources, for the promotion of this microbial process (Thiel and Hoppert 2018). In the present study, various fatty acyl compounds, modeling the variety of lipid substrates putatively present in a marine realm, were provided as carbon sources for microbial communities deriving from a marine sediment as inoculum. In microcosms, the formation of nanoscale siderite was induced by a microbial community dominated by sulfate-reducing bacteria (SRB).

\section{Materials and methods}

\section{Sampling}

A sample of Wadden Sea sediment was taken at approx. $53.89323 \mathrm{~N}, 8.67874 \mathrm{E}$. The sample used for inoculation was a mixture of layers between 0 and $15 \mathrm{~cm}$ below the surface. In order to reduce additional organic carbon sources, the sample was kept at $20^{\circ} \mathrm{C}$ for 6 months in order to promote microbial degradation of organic compounds and was then stored refrigerated until use.

\section{Microcosm experiments}

Microcosms were set up with artificial sea water with sea salt (200 ml, $35.0 \mathrm{~g} \mathrm{~L}^{-1}$; Merck KGaA, Darmstadt, Germany) and $100 \mathrm{~g}$ marine sediments as an inoculum and various lipid-based substrates ( $2 \%$ final concentration, respectively): linseed oil (Sigma/Merck 430021, Weinheim, Germany), Span 20, Span 80 (sorbitane monolaurate Sigma/Merck S6635, sorbitane monooleate Fluka/Sigma 85548), crude triglycerides (from coconut, medium chain triglycerides mainly $\mathrm{C}_{6}-\mathrm{C}_{12}$, Woldo Health, Hamburg, Germany) and lime soap (calcium stearate; Sigma/Merck 26411). All experiments were performed in triplicate. $300 \mathrm{ml}$-Erlenmeyer flasks for each substrate were incubated at $37^{\circ} \mathrm{C}$ without shaking. Flasks without substrate served as control.

\section{DNA extraction}

Samples from each flask were collected under sterile conditions after three and after fifteen days of incubation. The Power Soil DNA isolation kit (Qiagen, Hilden, Germany) was used for DNA extraction according to manufacturer's instructions, followed by size determination and quantification of extracted DNA. In brief, the sediment was suspended and $0.35 \mathrm{~g}$ of the resulting water/sediment mixture from each microcosm was homogenized with Power Bead tubes provided with the kit. The size of extracted DNA from each sample was estimated by agarose gel electrophoresis $(1 \% \mathrm{w} / \mathrm{v}$ agarose, $1 \mathrm{~kb}$ DNA size standard ladder; Thermofisher Scientific, Waltham, Mass. USA). DNA concentration of each sample was estimated in a NanoDrop spectrophotometer (Thermofisher Scientific). Of three replicates from each sample, PCR reactions for amplification of the V3 and V4 region of the bacterial $16 \mathrm{~S}$ rRNA were prepared (16S amplicon PCR forward primer: 5'-TCG TCG GCA GCG TCA GAT GTG TAT AAG AGA CAG CCT ACG GGN GGC WGC WGC AG-3'; 16S amplicon PCR reverse primer: 5'-
GTC TCG TGG GCT CGG AGA TGT GTA TAA GAG ACA GGA CTA CHV GGG TAT CTA ATCC-3'). In order to make the amplicons suitable for Illumina MiSeq sequencing, primers were additionally linked to overhang adapter sequences according to manufacturer's recommendations. Master Mix was prepared according to Klindworth et al. (2013), with some modifications: 5X Phusion GC Buffer $(10 \mu \mathrm{l}), \mathrm{MgCl}_{2} 25 \mathrm{mM}(0.15 \mu \mathrm{l})$, DMSO 5\% (2.5 $\left.\mu \mathrm{l}\right)$, reverse and forward primer (1:10 dilution) and dNTPs $10 \mathrm{mM}$ $(1 \mu \mathrm{l}), 2 \mathrm{U} / \mu \mathrm{l}$ Phusion HF DNA polymerase $(0.5 \mu \mathrm{l})$, template DNA $25 \mathrm{ng}(1 \mu \mathrm{l})$, filled up to the final volume of $50 \mu \mathrm{l}$ with double distilled nuclease free water. The PCR program was performed as follows. Initial denaturation at $98^{\circ} \mathrm{C}$ for $1 \mathrm{~min}$, followed by 25 cycles at $98^{\circ} \mathrm{C}$ for $45 \mathrm{~s}, 60^{\circ} \mathrm{C}$ for $45 \mathrm{~s}, 72^{\circ} \mathrm{C}$ for $30 \mathrm{~s}$, followed by $1 \mathrm{cycle}$ at $72^{\circ} \mathrm{C}$ for $5 \mathrm{~min}$.

For gel electrophoresis, $3 \mu \mathrm{l}$ of the PCR product solution was mixed with $1 \mu \mathrm{l}$ HDgreen stain (INTAS, Göttingen, Germany) and separated in a $1.3 \%(\mathrm{w} / \mathrm{v})$ agarose gel $/ 1 \times$ Tris-acetate-EDTA-buffer (TAE)-system (Sambrook et al. 2000) with a $100 \mathrm{bp}$ DNA ladder (Thermofisher Scientific) as size standard. Quantity of DNA was estimated with a NanoDrop photometer (Thermofisher Scientific). Target amplicons ( $~ 500 \mathrm{bp})$ were size selected using a GeneRead Size Selection Kit (Qiagen). Sequencing was performed in an Illumina MiSeq desktop sequencer (Illumina, San Diego, CA), using the MiSeq Reagent Kit v3 $(2 \times 300$ bp paired-end reads; Illumina).

\section{Sequencing data process}

Sequences were analyzed after Illumina MiSeq processing as described by Egelkamp et al. (2017). Operational taxonomic unit (OTU) tables, alpha/beta diversity plots, PCoA (principal coordinate analysis) plots and bar charts were generated with QIIME 1.9.1 scripts (Caporaso et al. 2010; Kuczynski et al. 2011). PEAR (https://cme.h-its.org/exelixis/web/software/pear/) was performed to merge the forward and reverse reads. QIIME was used for quality filtering of the merged reads. Cutadapt (Martin 2011) was used to remove forward and reverse primer sequences. Sequences were then size filtered, dereplicated, clustered at $97 \%$ genetic similarity to generate operational taxonomic units (OTUs) by using USEARCH 9.2.64 (Edgar 2010), followed by a de novo and reference-based chimera check performed by UCHIME (Edgar et al. 2011). The BLAST alignment was performed for taxonomic classification against the SILVA database 128 (Quast et al. 2012).

\section{Light microscopy}

Light microscopic observations were performed using a Motic BA310E microscope (Motic GmbH, Wetzlar, Germany) with phase contrast optics and equipped with a Color view III camera (Motic GmbH). For this, samples of $30 \mu \mathrm{l}$ volume were taken and observed for presence of mineral precipitates. Micrographs were processed using the cell D image software (Motic $\mathrm{GmbH}$ ). 


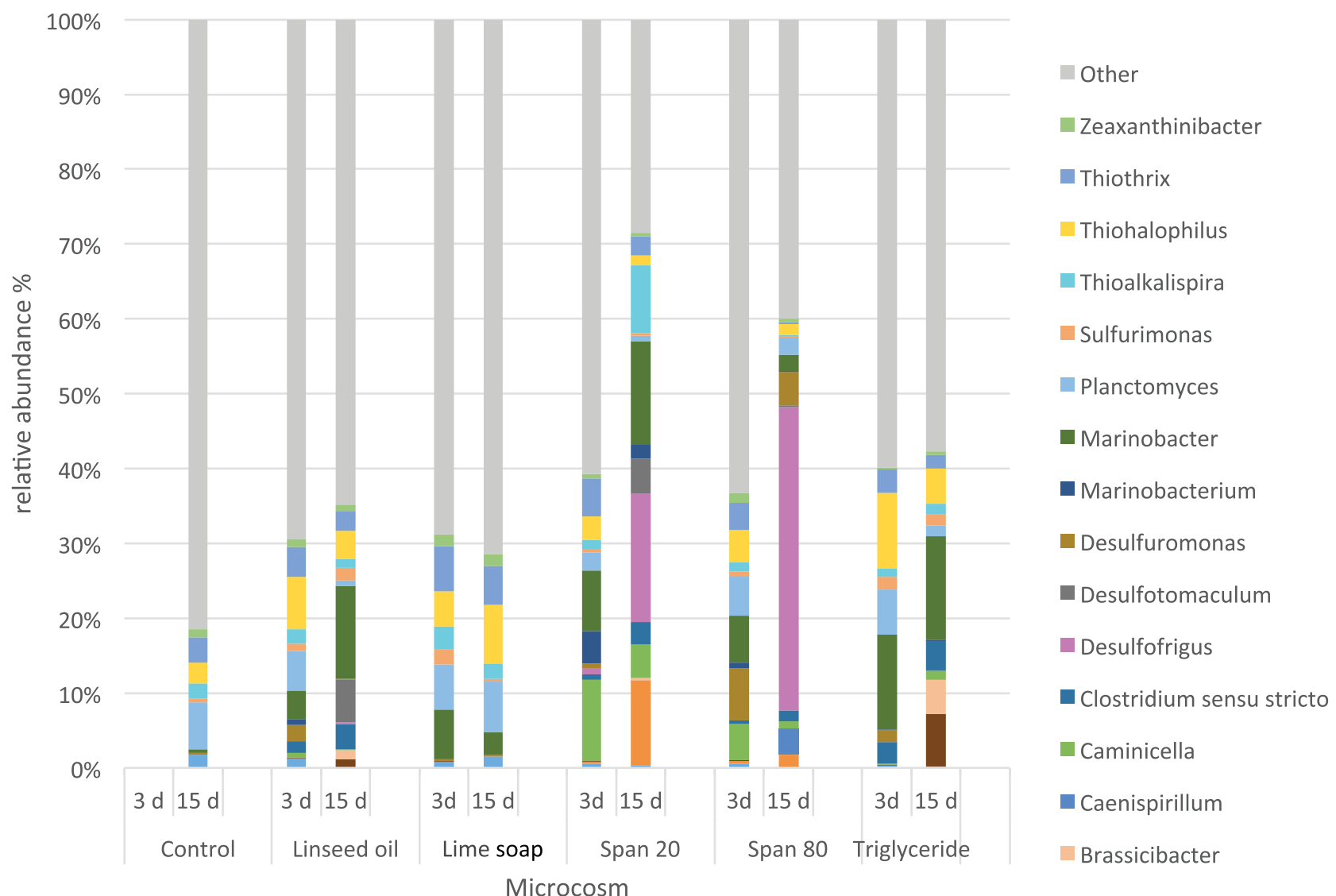

Figure 1. OTUs of prominent microbial community members ( $2 \%$ and higher relative abundance) present in the various microcosms after 3 and 15 days of incubation with various substrates as indicated. A single OTU is represented by a color in the clustered stack column; the area of each stack shows the relative abundance of the respective sequence. In the column, taxa representing less than $2 \%$ of all OTU's are shown as 'Other' (grey color).

Fluorescence in situ hybridization (FISH) was performed according to Kokoschka et al. (2015). For FISH analysis, the SRB385 probe (Amann et al. 1990), coupled to Cy3 fluorescent dyes, was used. DAPI (4', 6-diamidino-2-phenylindole, $1 \mu \mathrm{g} / \mathrm{ml}$, AppliChem, Darmstadt) was used for staining of nucleoids, resulting in a blue 'background' fluorescence of all prokaryotic cells. Fluorescence light microscopy was performed with a Zeiss Axioskop fluorescence microscope (Zeiss, Göttingen, Germany) equipped with an AxioCam $\mathrm{MRm}$ camera (Zeiss) at calibrated magnifications. Cy3 fluorescence was detected with a Chroma 41007a filter cube (Chroma, Bellows Falls, Vermont, USA). For DAPI fluorescence, the filter cube 49 (Zeiss) was used.

\section{Transmission electron microscopy and scanning transmission electron microscopy}

For transmission electron microscopy (TEM), $0.5 \mathrm{ml}$ of sample volumes were taken from microcosms. Samples were transferred to $1.5 \mathrm{ml}$ Eppendorf tubes and gently washed with $50 \mathrm{mM}$ phosphate buffered saline ( $\mathrm{pH}$ 7.0-7.5). Glutardialdehyde solution was added to the sample volume with a final concentration of $2.5 \%(\mathrm{v} / \mathrm{v})$; the resulting preparation was incubated at $0{ }^{\circ} \mathrm{C}$ for $90 \mathrm{~min}$ with gentle shaking. Then the solution was removed and the sample was washed three times with deionized water. $500 \mu \mathrm{l}$ of $2.5 \%$ $(\mathrm{w} / \mathrm{v})$ aqueous solution of molten agar, kept at $55^{\circ} \mathrm{C}$, was added to the sample and incubated for $3 \mathrm{~min}$ in an ice bath. The solidified agar with sample embedded was gently removed and cut into $1 \mathrm{~mm}^{3}$-pieces. The sample was covered with ruthenium red stain $(1 \%, \mathrm{w} / \mathrm{v})$ for $20 \mathrm{~min}$ and subsequently washed with distilled water five times. For dehydration, the sample was incubated at $0{ }^{\circ} \mathrm{C}$ with $15 \%(\mathrm{v} /$ v) ethanol for $15 \mathrm{~min}$, then with $30 \%, 50 \%, 70 \%$ and $95 \%$ ethanol for $30 \mathrm{~min}$, respectively, and finally in $100 \%$ ethanol two times for $30 \mathrm{~min}$. For embedding, samples were incubated with 66.6\% LR White resin (London Resin CO Ltd., Reading, UK) in ethanol at $25^{\circ} \mathrm{C}$ for $2 \mathrm{~h}$, followed by overnight incubation in $100 \%$ resin at $4{ }^{\circ} \mathrm{C}$. Afterwards, the sample was transferred into gelatin capsules and polymerized in $100 \%$ resin for $12 \mathrm{~h}$ at $55^{\circ} \mathrm{C}$. Samples were cut into $80 \mathrm{~nm}$ ultrathin sections by ultramicrotomy (Reichert Ultracut $\mathrm{E}$ ultramicrotome, Leica Biosystems, Wetzlar, Germany) with diamond knives (DDK, Wilmington, Delaware, USA) and supported by formvar-coated 300 mesh copper grids (Plano GmbH, Wetzlar; cf. Hoppert and Holzenburg 1998). Sections were stained for $20 \mathrm{~min}$ with Uranyl Acetate Replacement Stain (Electron Microscopy Sciences, Hatfield, PA). Electron microscopy was carried out on a Jeol 1011 electron microscope (Jeol GmbH, Freising, Germany). Images were captured using a Gatan Orius $4 \mathrm{~K}$ camera and processed with the Gatan 314 Digital Micrograph software package (Gatan GmbH, Munich, Germany) and Adobe Photoshop CS2 (Adobe Systems Inc., Jan José, Cal., USA). The sections were also analyzed in a Tecnai 12 Spirit 


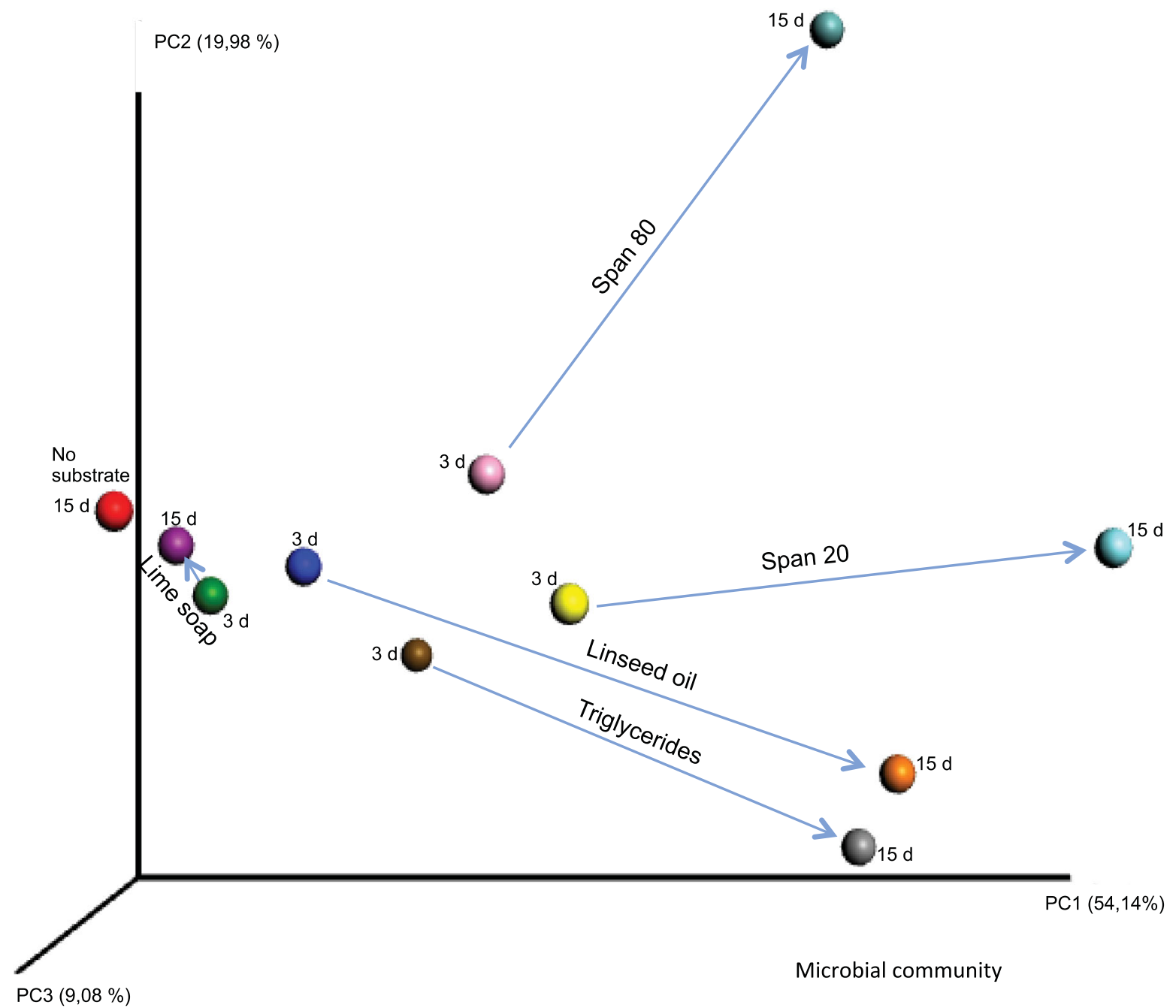

Figure 2. Weighted PCoA plot: Microbial communities in microcosms with different substrates as indicated after 3 days and 15 days of incubation.

BioTwin (FEI Europe B.V., Eindhoven, the Netherlands) operated at $120 \mathrm{kV}$ and equipped with a detector for energy dispersive X-ray spectroscopy (EDX; EDAX International, Mahwah, New Jersey, USA) operated in scanning transmission electron microscopy (STEM) mode. The bright and dark field images were collected using a Fischione 3000 Annular Dark Field (ADF) Detector (E.A. Fischione Instr., Pennsylvania, USA). Imaging, signal processing analysis and quantification of the EDX signal was performed with the FEI TEM Imaging and Analysis Software (FEI Europe).

\section{Results}

Samples from microcosms with and without (as a control) substrates were subjected to DNA extraction and Illumina sequencing 3 days and 15 days after inoculation with marine sediment. The microcosms were incubated at $37^{\circ} \mathrm{C}$ without shaking which rapidly creates dysoxic conditions due to initial oxygen consumption by aerobic bacteria.

For all microcosms more than 25,000 sequences per sample were received, varying between 32,181 (Span 80 as substrate) and 40,118 (triglycerides) 3 days after inoculation and 28,160 (triglycerides) and 33,774 (linseed oil) after 15 days. Rarefaction curves (Supplement) do not reach a plateau, but still show considerable differences in expected species numbers per sample, with highest alpha diversity in the control sample and lowest diversity in Span 20 and Span 80 microcosms 15 days after inoculation. The relative abundance of frequent OTUs (operational taxonomic unit $[\mathrm{s}]$, based on sequences with similarities above 97\%) obtained from each substrate microcosm sample is shown in Figure 1.

During 15 days of culturing, the microcosms diversify and show divergent microbial communities, as illustrated by Principal Coordinates Analysis (PCoA, Figure 2). The weighted and unweighted (not depicted) PCoA plot show that the beta diversity of the microbial communities in samples drawn after 3 days from lime soap, linseed oil, triglyceride, Span 20 and 80 are very close to each other, whereas after 15 days, communities in Span 20 and Span 80 are explicitly distinct from each other and also from other samples. The lime soap microcosm after 15 days is similar with the control (without additional substrate).

Most abundant in all samples were Marinobacter and Thiohalophilus with $13.8 \%$ and $10.1 \%$ of all OTUs, according to the relative numbers of sequences. Other prominent species included Anaerosporobacter (11.2\%) in Span 20, Planctomyces $(6.8 \%)$ in lime soap and Thiothrix $(6.0 \%)$ in lime soap. In media supplemented with sorbitane 


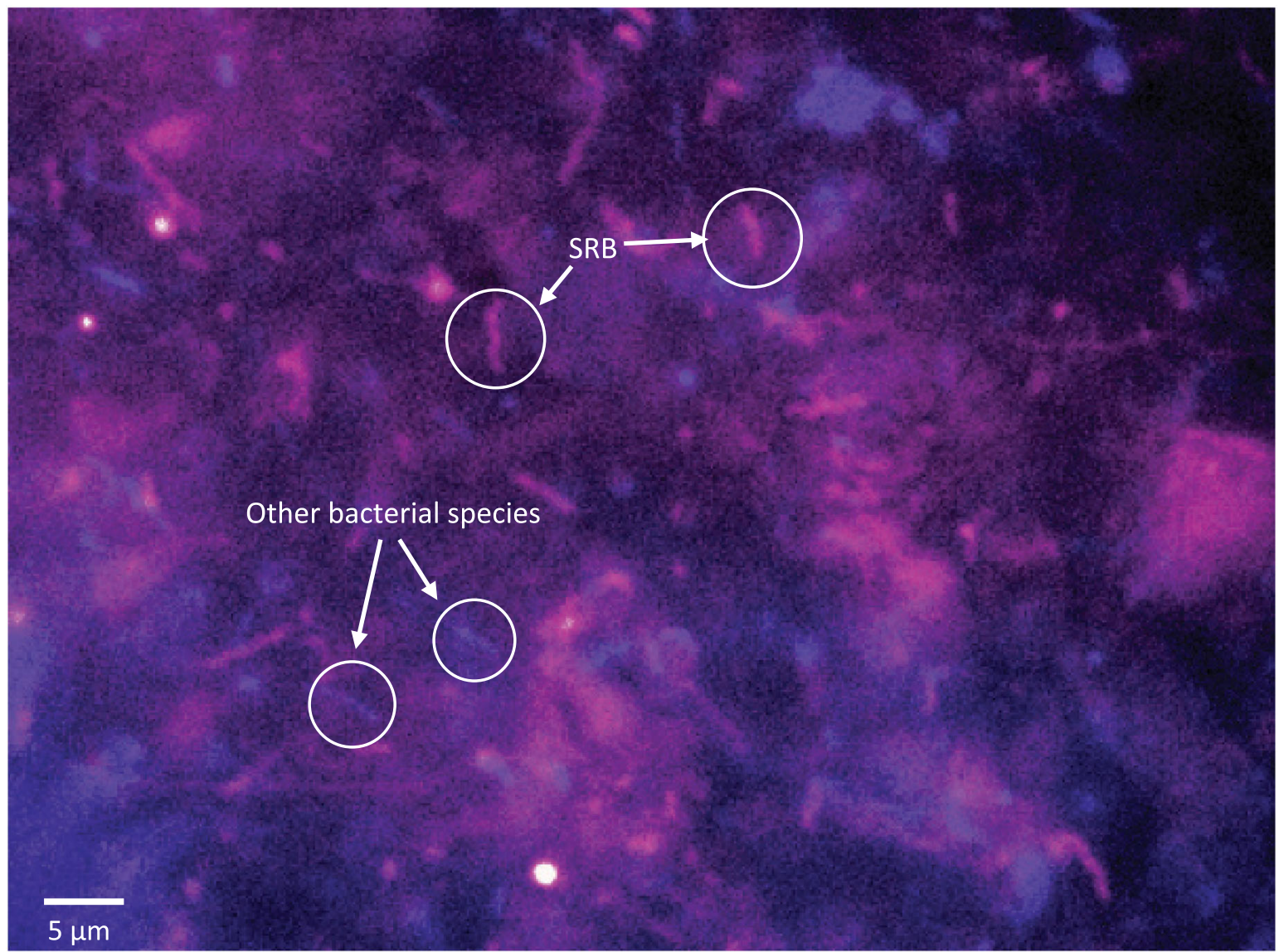

Figure 3. Sample taken from a Span 80 microcosm stained with DAPI and FISH probe SRB385. Cells of sulfate-reducing bacteria (SRB) appear in pink; cells of other prokaryotes appear in blue.

monostearates (Span), SRB represented $48.6 \%$ (sorbitan monooleate, Span 80) and $17.2 \%$ (sorbitan monolaurate, Span 20) after 15 days of incubation. In lime soap media, only $1.18 \%$ of all OTUs were assigned to SRB. In contrast, in microcosms containing Span 80, Desulfofrigus sp. (Deltaproteobacteria) represented more than $40 \%$ of all sequences after 15 days of incubation. The presence of SRB was also confirmed by FISH (Figure 3), using a probe established for deltaproteobacterial sulfate reducers (Amann et al. 1990). SRB were abundant and were distributed among sediment particles along with other microbial cells exhibiting only DAPI fluorescence (all prokaryotes). Other abundant sulfate reducers were Desulfotomaculum (Clostridiales; in linseed oil and Span 20) and Desulfuromonas (Deltaproteobacteria). The latter was abundant in Span 80 mesocosms 3 days after inoculation, but was completely replaced by Desulfofrigus after 15 days. All other retrieved OTUs of sulfate reducers (27 in total, all assigend to Deltaproteobacteria) were present in amounts of less than $1 \%$ of all sequences per sample. Since mineral precipitates were found to be most abundant in Span 20 and Span 80 media, further analysis were focused on these microcosms.

Light microscopy revealed the presence of obvious mineral precipitates exclusively in the Span 80 and Span 20 samples (cf. Figure 4). The birefringent (not shown) precipitates form roundish aggregates composed of smaller crystallites of elongate shapes, surrounding bacterial cell clusters. TEM of ultrathin sections prepared from Span 80-microcosm samples revealed electron dense mineral accumulations (appearing darker than the bacterial cells) attached to their cell envelopes (Figure 5(A-D)). However, some bacteria were without any mineral coating (Figure 5(A,D)). In addition, precipitates surrounding cells were observed in microcosms with triglyceride as substrate (Figure 5(E,F)). These precipitates formed smaller clusters, other than observed for Span 80 (cf. Figure 4).

STEM/EDX revealed the presence of iron in the dark accumulations according to analysis of the X-ray signal (Figure 6(A)). In larger mineral precipitates (cf. Figure 5(A)) traversing the whole section and not covered by embedding resin, the spectra are fully consistent with the stoichiometry of $\mathrm{FeCO}_{3}$ (i.e., siderite; Figure 6(B)). In the thin linings, iron was also clearly detected; however, it could not be conclusively confirmed from the EDX spectra that these minerals consist of siderite due to the influence of the embedding resin on the X-ray signal. No other elements could be detected in these precipitates.

\section{Discussion}

The aim of this study is to evaluate microbial communities involved in the formation of concretions, in the course of degradation of lipids released from animal tissue or other sedimentary organic matter. It has long been recognized that microbes may contribute to the formation of carbonate sediments by their various metabolic activities. For instance, 

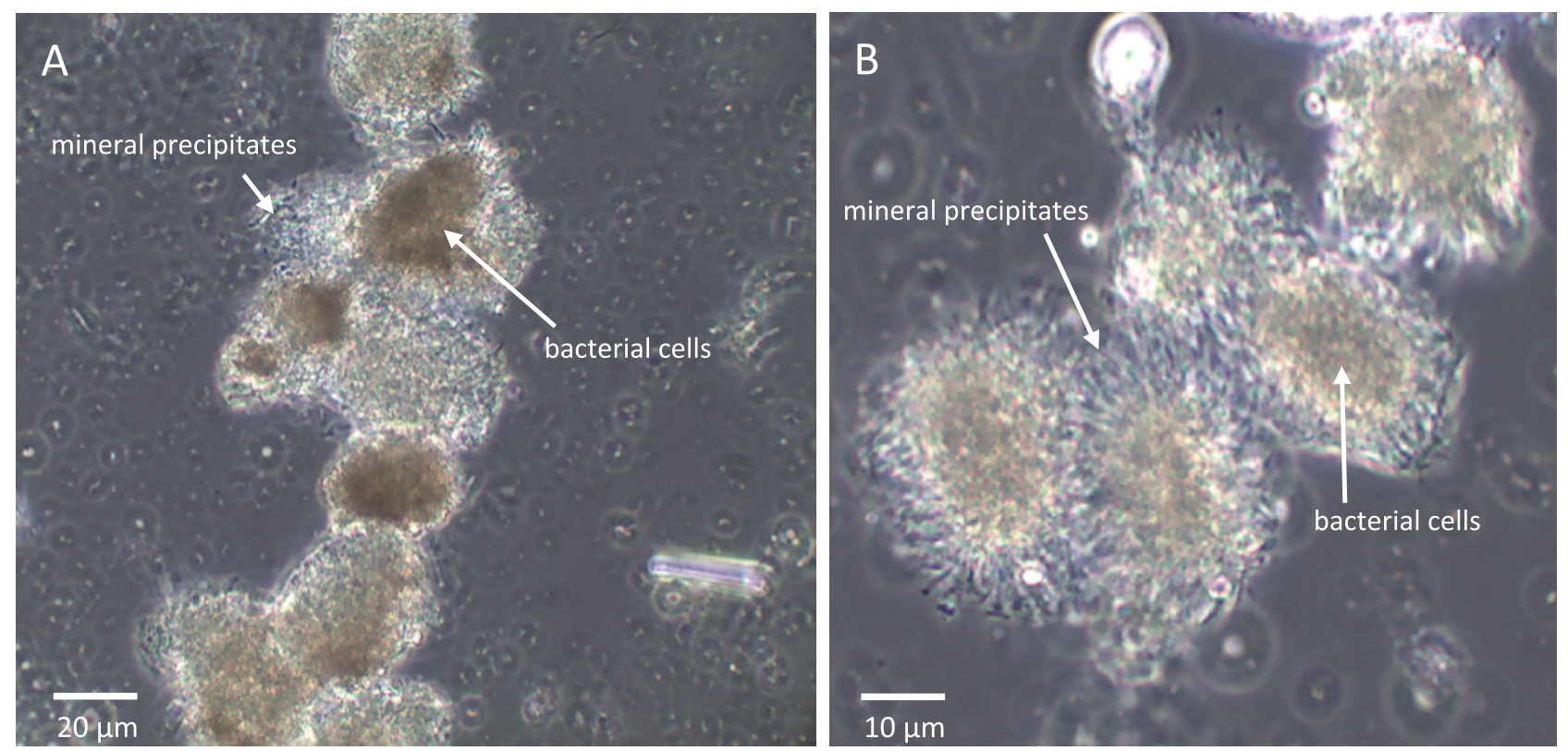

Figure 4. Light microscopy of mineral precipitates surrounding bacterial cell clusters in a microcosm grown on Span 80 as substrate (A and B display different magnifications).

photosynthesis, sulfate reduction and ammonification increase $\mathrm{pH}$ and accelerate carbonate precipitation, according to, e.g.,

$$
\mathrm{Me}^{2+}+2 \mathrm{HCO}_{3}^{-} \rightarrow \mathrm{MeCO}_{3}+\mathrm{H}_{2} \mathrm{O}+\mathrm{CO}_{2}
$$

for divalent metal ions (Castanier et al. 1999; García et al. 2016; Van Lith et al. 2003; Vasconcelos and McKenzie 1997; Visscher et al. 1998; Warthmann et al. 2000; Wei et al. 2015). In nature, $\mathrm{Mg}^{2+}, \mathrm{Ca}^{2+}, \mathrm{Fe}^{2+}$ and $\mathrm{Mn}^{2+}$ are relevant counter ions in the formation of carbonates. All of them are involved in formation of carbonate precipitates, frequently influenced by microorganisms (e.g., Dupraz et al. 2009). In the photic zones of aquatic ecosystems, oxygenic photosynthesis has been since long recognized as main driver of microbially induced calcification (Borowitzka and Larkum 1987). However, the contribution of oxygenic photosynthetic bacteria to net precipitation of calcium carbonate is still a matter of debate - though there is no doubt that cyanobacterial mats shape carbonate buildups (see, e.g., Arp et al. 2003; Shiraishi et al. 2008). Under anoxic conditions, bacterial sulfate reduction is the major process of organic matter oxidation in marine sediment (Gaillard et al. 1989) and is supposed to be important for biogenic formation of calcite and aragonite (Briggs 2003; Dupraz et al. 2009; Zhu and Dittrich 2016). Further, the $\mathrm{Ca}^{2+}$ concentration can also be increased in microenvironments of biofilms by active release from microbial extracellular polymeric substances (mainly exopolysaccharides) during degradation (Arp et al. 2003; Braissant et al. 2007). Increased concentration of both $\mathrm{HCO}_{3}{ }^{-}$and $\mathrm{Ca}^{2+}$ enhances $\mathrm{CaCO}_{3}$ precipitation (Anbu et al. 2016; Gaillard et al. 1989; Zhu and Dittrich 2016) according to:

$$
\mathrm{Ca}^{2+}+\mathrm{HCO}_{3}^{-} \rightarrow \mathrm{CaCO}_{3}+\mathrm{H}^{+}
$$

As a result, conditions are conducive for concretion formation (Briggs 2003).
Over geological timescales, mineralization processes induced by microorganisms have a great significance for the preservation of fossils (Cotroneo et al. 2016; Riding and Liang 2005; Zhu and Dittrich 2016), which is also true for those encased in siderite concretions. For the Upper Carboniferous Mazon Creek siderite concretions, isotopic signatures of oxygen, carbon and sulfur implied that sulfate was limited during the initial stages of concretion formation. Hence, siderite was formed besides variable amounts of pyrite. The resulting 'protoconcretion' was later cemented by additional siderite formed from continuous supply of carbonate during methanogenesis (Cotroneo et al. 2016), which may be summarized as follows (Morad 1998):isotopic signatures

$$
2 \mathrm{Fe}_{2} \mathrm{O}_{3}+7 \mathrm{CH}_{2} \mathrm{O} \rightarrow 4 \mathrm{FeCO}_{3}+3 \mathrm{CH}_{4}+\mathrm{H}_{2} \mathrm{O}
$$

Biomarker studies on Lower Jurassic phosphate- and siderite-rich concretions indicated that SRB contributed to the degradation of initially fatty acyl-rich material and have been involved in the initial concretion-forming process (Thiel and Hoppert 2018). This is now supported by our microcosm data. Indeed, Desulfofrigus isolates, in particular Desulfofrigus oceanense, have been reported to degrade fatty acids of even higher chain lengths (Knoblauch et al. 1999), which may explain the dominance of Desulfofrigus-related OTUs in sorbitan monooleate-containing medium. The fatty acids are either completely oxidized to $\mathrm{CO}_{2}$ or incompletely to acetate (Knoblauch et al. 1999). In our microcosm experiments, however, not all substrates are evenly attractive for SRB and consequently their abundances at the end of the microcosm experiments diverged strongly (Figures 1 and 2). The results suggest that the emulsifying properties of Span 20 and Span 80 may have increased the accessibility of the lipid substrate for microorganisms, particularly SRB. On the other hand, the insoluble and hydrophobic lime soap was much more resistant against microbial attack. On the short 

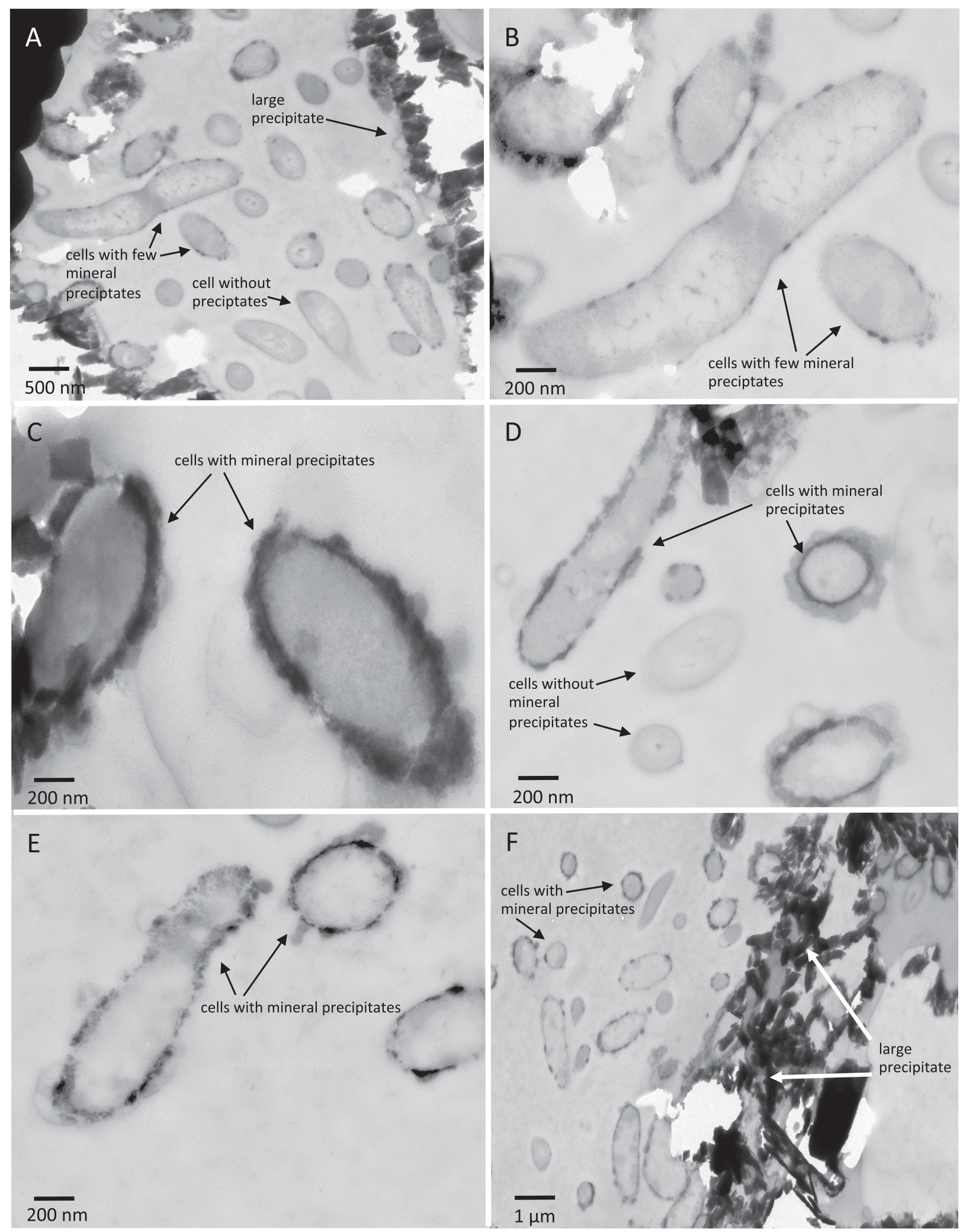

Figure 5. Transmission electron microscopy of bacterial cells present in microcosms on Span $80(A-D)$ and triglycerides as substrates (E,F), exhibiting mineral precipitates associated with cell envelopes and large precipitates traversing a whole section.

time scale of our experiments, this substrate did not alter the microbial community, as compared to a microcosm control without any substrate added.
The Desulfofrigus-dominated communities produced siderite, at a microscale, as revealed by STEM. It has to be pointed out that the siderite-encased cells are not necessarily 

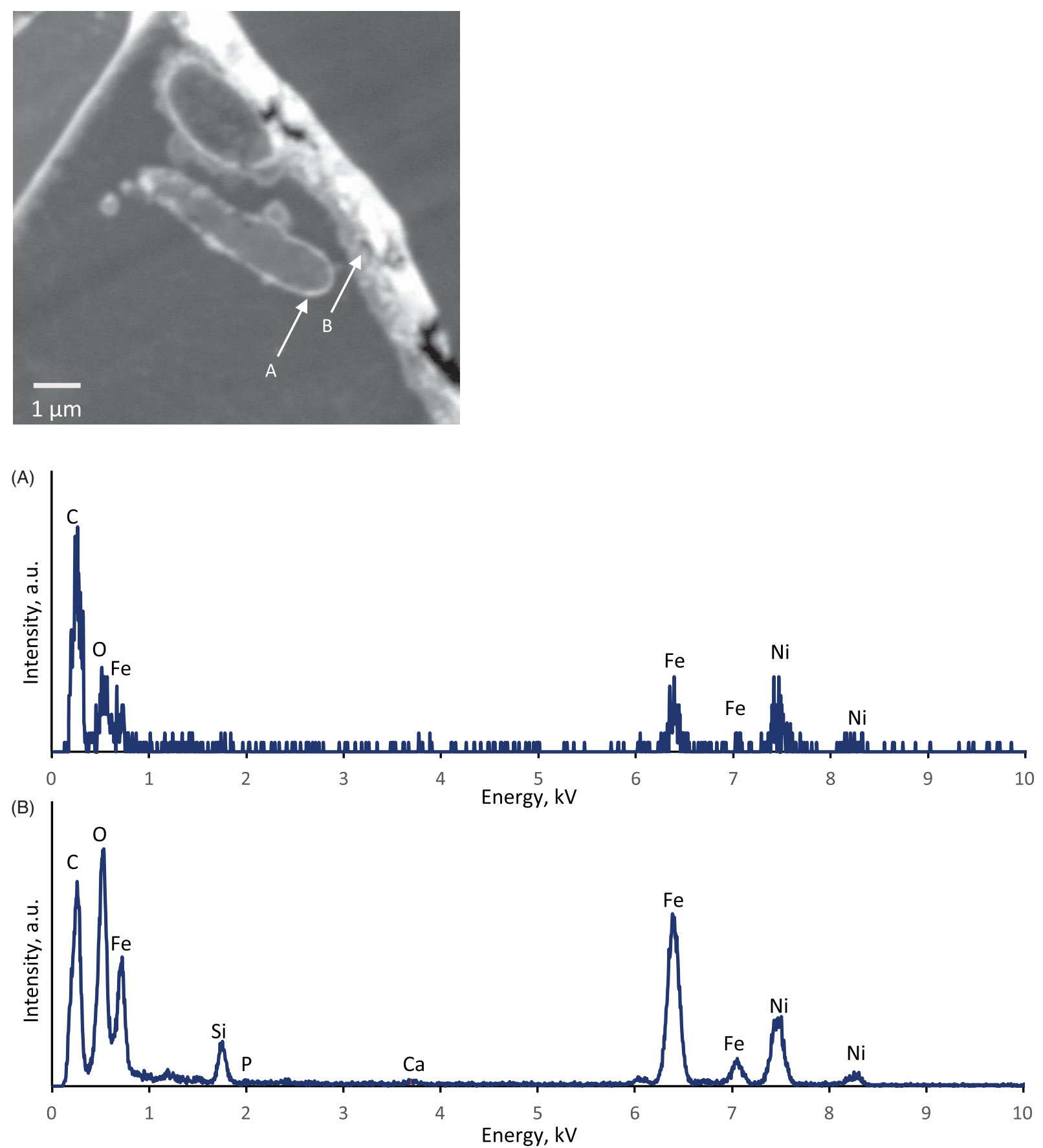

Figure 6. Scanning transmission electron microscopy of mineral precipitates surrounding a microbial cell (A) and a large precipitate (B) in an ultrathin section of a sample taken from a Span 80 microcosm. Arrows point to the analyzed areas. EDX spectra of the areas are shown in A and B with prominent peaks of iron, carbon and oxygen. In B, carbon, oxygen and iron peaks match to siderite stochiometry aSer EDX signal quantification.

producers of the mineral, but may just provide an organic surface for precipitation. In contemporary anoxic sediments and active microbial communities, iron sulfides are commonly formed as a result of bacterial sulfate reduction (e.g., Birnbaum and Wireman 1984; Picard et al. 2016 for overview). Nonetheless, siderite formation has also been observed, such as in salt marsh sediments (Coleman et al. 1993; Morad 1998), or as a result of microbial iron metal corrosion (Enning et al. 2012). Further, Mortimer et al. (2011) confirmed the formation of siderite in biotic microcosms derived from anoxic salt marsh sediments. A plausible explanation for the formation of siderite particularly in Fe- rich settings is the heterotrophic Fe(III) reduction conducted by several Desulfovibrionaceae, including Desulfofrigus isolates (Knoblauch et al. 1999), according to:

$$
\begin{aligned}
& 4 \mathrm{Fe}(\mathrm{OH})_{3}+\mathrm{CH}_{2} \mathrm{O}+7 \mathrm{H}^{+} \\
& \quad \rightarrow 4 \mathrm{Fe}_{\mathrm{aq}}^{2+}+\mathrm{HCO}_{3}^{-}+10 \mathrm{H}_{2} \mathrm{O}
\end{aligned}
$$

Here, iron(III) instead of sulfate is used as an electron acceptor for the oxidation of organic matter to carbon dioxide. In laboratory experiments, some SRB have been shown to effectively reduce dissolved $\mathrm{Fe}$ (III) citrate (Loveley et al. 1993). Even clay mineral-bound iron may be utilized by SRB (Liu et al. 2012). Generally, however, iron reduction in 
anoxic sediments is more effectively conducted by iron reducing genera like Shewanalla, Geobacter and related taxa (Richter et al. 2012). These organisms are capable of reducing poorly soluble iron oxide-hydroxides at neutral $\mathrm{pH}$. In addition, Thermoanaerobacter ethanolicus has been found to be involved in siderite formation in enrichment cultures (Zhang et al. 2009). In the microcosms of our study, Thermoanaerobacter genera were absent, and Geoalkalibacter and Geothermobacter represent only up to 1-2 percent of all sequences retrieved. Whereas the latter may have contributed to the pool of reduced iron in our microcosms, SRB, in particular Desulfofrigus, are much more abundant, pointing at a major role of this group for the siderite formation observed in our experiments.

In addition to microbial iron reduction, release of $\mathrm{Fe}^{2+}$ ions during oxidation of FeS to $S^{0}$ may occur abiotically according to (Mortimer et al. 2011):

$$
\begin{gathered}
\mathrm{FeS}+2 \mathrm{FeO}(\mathrm{OH})+2 \mathrm{H}_{2} \mathrm{O} \\
\rightarrow 3 \mathrm{Fe}_{\mathrm{aq}}^{2+}+\mathrm{S}^{0}+6 \mathrm{OH}^{-}
\end{gathered}
$$

$\mathrm{Fe}^{2+}$ may then form siderite with carbonate ions derived from microbial oxidation of organic compounds:

$$
\mathrm{Fe}_{\mathrm{aq}}^{2+}+\mathrm{CO}_{3 \mathrm{aq}}^{2-} \rightarrow \mathrm{FeCO}_{3}
$$

A lithotrophic growth with metallic iron $\left(\mathrm{Fe}^{0}\right)$ as electron donor is possible, when organic electron donors are absent, which leads to the formation of siderite $\left(\mathrm{FeCO}_{3}\right)$ and mackinawite (FeS; Enning et al. 2012; Enning and Garrelfs 2014):

$$
\begin{gathered}
4 \mathrm{Fe}^{0}+\mathrm{SO}_{4}^{2-}+3 \mathrm{HCO}_{3}^{-}+\mathrm{H}_{2} \mathrm{O} \\
\rightarrow \mathrm{FeS}+3 \mathrm{FeCO}_{3}+5 \mathrm{OH}^{-}
\end{gathered}
$$

Because of the absence of $\mathrm{Fe}^{0}$, however, the reaction is not relevant for the microcosms of this study.

Analysis of samples by electron microscopy frequently revealed the involvement of organic surfaces, produced by microorganisms, in carbonate mineral formation (e.g., Casanova et al. 1999; Rivadeneyra et al. 2000; Van Lith et al. 2003). STEM in this study demonstrates the involvement of microbial consortia in mineral adsorption. Various bacterial morphotypes were observed with or without mineral accumulation, in particular in the samples with triglyceride, Span 20, and Span 80 as substrates. Generally, spatially ordered acidic groups (e.g., $\mathrm{R}-\mathrm{COO}^{-}, \mathrm{R}-\mathrm{O}-\mathrm{SO}_{3}{ }^{-}, \mathrm{R}-\mathrm{O}-\mathrm{PO}_{3}{ }^{2-}$ ) at microbial cell surfaces may bind $\mathrm{Ca}^{2+}$ or $\mathrm{Mg}^{2+}$ at neutral $\mathrm{pH}$ and thus provide nucleation sites for calcite deposition (e.g., Anbu et al. 2016; Arp et al. 2001; Braissant et al. 2007; Dupraz et al. 2009; Spitzer et al. 2015). Bacterial cell surfaces also affect the crystallography of minerals formed (Anbu et al. 2016; Rodriguez-Navarro et al. 2012). Though bacterial capsules, sheaths, or other structures consisting of exopolymers were in our study neither visible by light microscopy nor by electron microscopy, it may be assumed that the cell surfaces (outer membranes) of cells surrounded by precipitates exhibit anionic sites that can bind cations including $\mathrm{Fe}^{2+}$ and $\mathrm{Ca}^{2+}$ (cf. Zhang-Sun et al. 2015). Until now, the formation of siderite minerals on bacterial envelopes has only been observed on cell surfaces of Acidiphilium
(Sánchez-Román et al. 2014). Precipitates of iron sulfides have been frequently observed during sulfate reduction, but they are not necessarily tightly attached to the surfaces of outer membranes (Kokoschka et al. 2015; Picard et al. 2018).

The present study shows that at high concentrations of apparently easily degradable lipids, microbial communities dominated by SRB induce the formation of siderite at the nano- and microscale. The microcosms may be a suitable model for the involvement of microbial communities in carbonate concretion formation in marine settings. The microcosms also show that (lipidic) substrates greatly influence the composition of the community. In marine sediments, these lipids may derive from the later fossilized organism in the center of a siderite concretion, but may also be delivered to the sediment from other water column organisms. Mesozooplankton, such as copepods, as well as many algae are known to contain vast amounts of storage lipids (Cagliari et al. 2011; Jónasdóttir et al. 2015). Under certain conditions, accumulation of these lipid resources in surface sediments may create the fuel for microbially induced siderite precipitation.

\section{Acknowledgements}

We gratefully acknowledge the thoughtful comments provided by the anonymous reviewers.

\section{Disclosure statement}

No potential conflict of interest was reported by the author(s).

\section{Funding}

This study was financially supported by the German Research Foundation [Th 713/12-1].

\section{References}

Amann RI, Binder BJ, Olson RJ, Chisholm SW, Devereux R, Stahl DA. 1990. Combination of 16S rRNA-targeted oligonucleotide probes with flow cytometry for analyzing mixed microbial populations. Appl Environ Microbiol 56(6):1919-1925.

Anbu P, Kang CH, Shin YJ, So JS. 2016. Formations of calcium carbonate minerals by bacteria and its multiple applications. Springerplus 5(1):250.

Arp G, Reimer A, Reitner J. 2001. Photosynthesis-induced biofilm calcification and calcium concentrations in Phanerozoic oceans. Science 292(5522):1701-1704.

Arp G, Reimer A, Reitner J. 2003. Microbialite formation in seawater of increased alkalinity, Satonda Crater Lake, Indonesia. J Sediment Res 73(1):105-127.

Birnbaum SJ, Wireman JW. 1984. Bacterial sulfate reduction and $\mathrm{pH}$ : implications for early diagenesis. Chem Geol 43(1-2):143-149.

Bojanowski MJ, Clarkson EN. 2012. Origin of siderite concretions in microenvironments of methanogenesis developed in a sulfate reduction zone: an exception or a rule? J Sediment Res 82(8):585-598.

Borowitzka MA, Larkum AWD. 1987. Calcification in algae: mechanism and the role of metabolism. Crit Rev Plant Sci 6(1):1-45.

Braissant O, Decho AW, Dupraz C, Glunk C, Przekop KM, Visscher PT. 2007. Exo-polymeric substances of sulfate-reducing bacteria: 
interactions with calcium at alkaline $\mathrm{pH}$ and implication for formation of carbonate minerals. Geobiology 5(4):401-411.

Briggs DE. 2003. The role of decay and mineralization in the preservation of soft bodied fossils. Annu Rev Earth Planet Sci 31(1):275-301.

Cagliari A, Margis R, dos Santos Maraschin F, Turchetto-Zolet AC, Loss G, Margis-Pinheiro M. 2011. Biosynthesis of triacylglycerols (TAGs) in plants and algae. Int J Plant Biol 2(1):e10.

Caporaso JG, Kuczynski J, Stombaugh J, Bittinger K, Bushman FD, Costello EK, Fierer N, Pena AG, Goodrich JK, Gordon JI, et al. 2010. QIIME allows analysis of high-throughput community sequencing data. Nat Methods 7(5):335-336.

Casanova J, Bodénan F, Négrel P, Azaroual M. 1999. Microbial control on the precipitation of modern ferrihydrite and carbonate deposits from the Cézallier hydrothermal springs (Massif Central, France). Sediment Geol 126(1-4):125-145.

Castanier S, Le Métayer Levrel G, Perthuisot JP. 1999. Ca-carbonate precipitation and limestone genesis - the microbiogeologist point of view. Sediment Geol 126(1-4):9-23.

Clements T, Purnell M, Gabbott S. 2019. The Mazon Creek Lagerstätte: a diverse late Paleozoic ecosystem entombed within siderite concretions. J Geol Soc 176(1):1-11.

Coleman ML, Hedrick DB, Lovley DR, White DC, Pye K. 1993. Reduction of $\mathrm{Fe}(\mathrm{III})$ in sediments by sulphate-reducing bacteria. Nature 361(6411):436-438.

Cotroneo S, Schiffbauer J D, McCoy V E, Wortmann U G, Darroch S A F, Peng Y, Laflamme M. 2016. A new model of the formation of Pennsylvanian iron carbonate concretions hosting exceptional soft-bodied fossils in Mazon Creek, Illinois. Geobiology 14(6): 543-555.

Darroch SAF, Laflamme M, Schiffbauer JD, Briggs D. 2012. Experimental formation of a microbial death mask. Palaios 27(5): 293-303.

Dupraz C, Reid RP, Braissant O, Decho AW, Norman RS, Visscher PT. 2009. Processes of carbonate precipitation in modern microbial mats. Earth-Sci Rev 96(3):141-162.

Edgar RC. 2010. Search and clustering orders of magnitude faster than BLAST. Bioinformatics 26(19):2460-2461.

Edgar RC, Haas BJ, Clemente JC, Quince C, Knight R. 2011. UCHIME improves sensitivity and speed of chimera detection. Bioinformatics 27(16):2194-2200.

Egelkamp R, Schneider D, Hertel R, Daniel R. 2017. Nitrile-degrading bacteria isolated from compost. Front Environ Sci 5:58.

Enning D, Garrelfs J. 2014. Corrosion of iron by sulfate-reducing bacteria: new views of an old problem. Appl Environ Microbiol 80(4): $1226-1236$

Enning D, Venzlaff H, Garrelfs J, Dinh HT, Meyer V, Mayrhofer K, Hassel AW, Stratmann M, Widdel F. 2012. Marine sulfate-reducing bacteria cause serious corrosion of iron under electroconductive biogenic mineral crust. Environ Microbiol 14(7):1772-1787.

Fisher QJ, Raiswell R, Marshall JD. 1998. Siderite concretions from nonmarine shales (Westphalian A) of the Pennines, England; controls on their growth and composition. J Sediment Res 68(5): 1034-1045.

Gaillard J-F, Pauwels H, Michard G. 1989. Chemical diagenesis in coastal marine sediments. Oceanolog Acta 12:175-187.

García GM, Márquez GMA, Herrera HCX. 2016. Characterization of bacterial diversity associated with calcareous deposits and dripwaters, and isolation of calcifying bacteria from two Colombian mines. Microbiol Res 182:21-30.

Gautier DL. 1982. Siderite concretions; indicators of early diagenesis in the Gammon Shale (Cretaceous). J Sediment Res 52:859-871.

Gibson BM, Schiffbauer JM, Darroch S. 2018. Ediacaran-style decay experiments using mollusks and sea anemones. Palaios 33(5): 185-203.

Hoppert M, Holzenburg A. 1998. Electron Microscopy in Microbiology (Royal Microscopical Society Microscopy Handbooks 43). Oxford, UK: BIOS Scientific Publishers.

Jónasdóttir SH, Visser AW, Richardson K, Heath MR. 2015. Seasonal copepod lipid pump promotes carbon sequestration in the deep North Atlantic. Proc Natl Acad Sci USA 112(39):12122-12126.
Keupp H, Schweigert G. 2008. Juraphyllites mimatensis (d'Orbigny, 1845) (Ammonoidea: Phylloceratida), a Tethyan immigrant in the Upper Pliensbachian of Franconia (Jurassic, Southern Germany). Palaeodiversity 1:133-140.

Klindworth A, Pruesse E, Schweer T, Peplies J, Quast C, Horn M, Glöckner FO. 2013. Evaluation of general 16S ribosomal RNA gene PCR primers for classical and next-generation sequencing-based diversity studies. Nucleic Acids Res 41(1):e1.

Knoblauch C, Sahm K, Jorgensen BB. 1999. Psychrophilic sulfatereducing bacteria isolated from permanently cold Arctic marine sediments: description of Desulfofrigus oceanense gen. nov., sp. nov., Desulfofrigus fragile sp. nov., Desulfofaba gelida gen. nov., sp. nov., Desulfotalea psychrophila gen. nov., sp. nov. and Desulfotalea arctica sp. nov. Int J Syst Bacteriol 49:1631-1643.

Kokoschka S, Dreier A, Romoth K, Taviani M, Schäfer N, Reitner J, Hoppert M. 2015. Isolation of anaerobic bacteria from terrestrial mud volcanoes (Salse di Nirano, Northern Apennines, Italy). Geomicrobiol J 32(3-4):355-364.

Kuczynski J, Strombaugh J, Walters JA, González A, Caporaso JG, Knight R. 2011. Using QIIME to analyze 16S rRNA gene sequences from microbial communities. Curr Protoc Bioinformatics Chapter 10:Unit 10.7.

Liu D, Dong H, Bishop ME, Zhang J, Wang H, Xie S, Wang S, Huang L, Eberl DD. 2012. Microbial reduction of structural iron in interstratified illite-smectite minerals by a sulfate-reducing bacterium. Geobiology 10(2):150-162.

Loveley DR, Roden EE, Phillips EJP, Woodward JC. 1993. Enzymatic iron and uranium reduction by sulfate-reducing bacteria. Mar Geol 113:41-53.

Martin M. 2011. Cutadapt removes adapter sequences from highthroughput sequencing reads. EMBnet J 17(1):10-12.

Morad S. 1998. Carbonate cementation in sandstones: distribution patterns and geochemical evolution. Spec Publ Intl Ass Sediment 26: $1-26$.

Mortimer RJG, Galsworthy AMJ, Bottrell SH, Wilmot LE, Newton RJ. 2011. Experimental evidence for rapid biotic and abiotic reduction of Fe (III) at low temperatures in salt marsh sediments: a possible mechanism for formation of modern sedimentary siderite concretions. Sedimentology 58(6):1514-1529.

Parry LA, Smithwick F, Nordén KK, Saitta ET, Lozano-Fernandez J, Tanner AR, Caron JB, Edgecombe GD, Briggs DEG, Vinther J. 2018. Soft-bodied fossils are not simply rotten carcasses-toward a holistic understanding of exceptional fossil preservation. Bioessays 40(1):1700167.

Picard A, Gartman A, Clarke DR, Girguis PR. 2018. Sulfate-reducing bacteria influence the nucleation and growth of mackinawite and greigite. Geochim Cosmochim Acta 220:367-384.

Picard A, Gartman A, Girguis PR. 2016. What do we really know about the role of microorganisms in iron sulfide mineral formation? Front Earth Sci 4:68.

Postma D. 1982. Pyrite and siderite formation in freshwater and swamp sediments. Am J Sci 282(8):1151-1183.

Postma D. 1977. The occurrence and chemical composition of recent Fe-rich mixed carbonates in a river bog. J Sediment Petrol 41: 1089-1098.

Pye K, Dickson AD, Schiavon N, Coleman ML, Cox M. 1990 Formation of siderite-Mg-calcite-iron sulphide concretions in intertidal marsh and sandflat sediments, north Norfolk, England. Sedimentology 31:325-343.

Quast C, Pruesse E, Yilmaz P, Gerken J, Schweer T, Yarza P, Peplies J, Glöckner FO. 2012. The SILVA ribosomal RNA gene database project: improved data processing and web-based tools. Nucleic Acids Res 41(D1):D590-D596.

Richter K, Schicklberger M, Gescher J. 2012. Dissimilatory reduction of extracellular electron acceptors in anaerobic respiration. Appl Environ Microbiol 78(4):913-921.

Riding R, Liang L. 2005. Geobiology of microbial carbonates: metazoan and sea-water saturation state influences on secular trends during the Phanerozoic. Palaeogeogr Palaeoclimatol Palaeoecol 219(1-2): 101-115. 
Rivadeneyra MA, Delgado G, Soriano M, Ramos-Cormenzana A, Delgado R. 2000. Precipitation of carbonates by Nesterenkonia halobia in liquid media. Chemosphere 41(4):617-624.

Rodriguez-Navarro C, Jroundi F, Schiro M, Ruiz-Agudo E, GonzálezMuñoz MT. 2012. Influence of substrate mineralogy on bacterial mineralization of calcium carbonate: implications in stone conservation. Appl Environ Microbiol 78(11):4017-4029.

Sagemann J, Bale SJ, Briggs DE, Parkes RJ. 1999. Controls on the formation of authigenic minerals in association with decaying organic matter: an experimental approach. Geochim Cosmochim Acta 63(7-8):1083-1095

Sambrook J, MacCallum PD, Russel D. 2000. Molecular Cloning: A Laboratory Manual. 3rd ed. Cold Spring Harbour: CSH Laboratory Press.

Sánchez-Román M, Fernández-Remolar D, Amils R, Sánchez-Navas A, Schmid T, San Martin-Uriz P, Rodríguez N, McKenzie JA, Vasconcelos C. 2014. Microbial mediated formation of Fe-carbonate minerals under extreme acidic conditions. Sci Rep 4:47-67.

Shiraishi F, Reimer A, Bissett A, de Beer D, Arp G. 2008. Microbial effects on biofilm calcification, ambient water chemistry and stable isotope records (Westerhöfer Bach, Germany). Palaeogeogr Palaeoclimatol Palaeoecol 262(1-2):91-106.

Spitzer S, Brinkmann N, Reimer A, Ionescu D, Friedl T, De Beer D, Arp G. 2015. Effect of variable $p \mathrm{CO}_{2}$ on $\mathrm{Ca}^{2+}$ removal and potential calcification of cyanobacterial biofilms - an experimental microsensor study. Geomicrobiol J 32(3-4):304-315.

Thiel V, Hoppert M. 2018. Fatty acids and other biomarkers in two Early Jurassic concretions and their immediate host rocks (Lias $\delta$ Buttenheim clay pit, Bavaria, Germany). Org Geochem 120:42-55.
Tibbs SL, Briggs DEG, Prössl KF. 2003. Pyritisation of plant microfossils from the Devonian Hunsrück Slate of Germany. Paläontol Z 77(1):241-246.

Van Lith Y, Warthmann R, Vasconcelos C, McKenzie JA. 2003. Microbial fossilization in carbonate sediments: a result of the bacterial surface involvement in dolomite precipitation. Sedimentology 50(2):237-245.

Vasconcelos C, McKenzie JA. 1997. Microbial mediation of modern dolomite precipitation and diagenesis under anoxic conditions (Lagoa Vermelha, Rio de Janeiro, Brazil). J Sediment Res 67: 378-390.

Visscher P T, Reid R. P, Bebout B M, Hoeft S E, Macintyre I G, Thompson J A. 1998. Formation of lithified micritic laminae in modern marine stromatolites (Bahamas): the role of sulfur cycling. Am Mineral 83(11-12 Part 2):1482-1493.

Warthmann R, Van Lith Y, Vasconcelos C, McKenzie JA, Karpoff AM. 2000. Bacterially induced dolomite precipitation in anoxic culture experiments. Geology 28(12):1091-1094.

Wei S, Cui H, Jiang Z, Liu H, He H, Fang N. 2015. Biomineralization processes of calcite induced by bacteria isolated from marine sediments. Braz J Microbiol 46(2):455-464.

Zhang G, Dong H, Jiang H, Kukkadapu RK, Kim J, Eberl D, Xu Z. 2009. Biomineralization associated with microbial reduction of $\mathrm{Fe}^{3+}$ and oxidation of $\mathrm{Fe}^{2+}$ in solid minerals. Am Mineral 94(7): 1049-1058.

Zhang-Sun W, Augusto LA, Zhao L, Caroff M. 2015. Desulfovibrio desulfuricans isolates from the gut of a single individual: structural and biological lipid A characterization. FEBS Lett 589(1):165-171.

Zhu T, Dittrich M. 2016. Carbonate precipitation through microbial activities in natural environment, and their potential in biotechnology: a review. Front Bioeng Biotechnol 4:4 


\section{Cyanobacterial mats in calcite-precipitating serpentinite-hosted alkaline springs of the Voltri Massif, Italy}

Aysha Kamran ${ }^{1}$, Kathrin Sauter ${ }^{1}$, Andreas Reimer ${ }^{2}$, Theresa Wacker ${ }^{1,3}$, Joachim Reitner ${ }^{2,4}$, Michael Hoppert ${ }^{1}$

Published in

Microorganisms (2021) 9: 62. DOI: 10.3390/microorganisms9010062

${ }^{1}$ Institute of Microbiology and Genetics, Georg-August-University Göttingen, Grisebachstraße 8, 37077 Göttingen, Germany

${ }^{2}$ Göttingen Centre of Geosciences, Georg-August-University Göttingen, 37077 Göttingen, Germany

${ }^{3}$ MRC CMM University of Exeter, Geoffrey Pope Building, Stocker Road, Exeter EX4 UK4

${ }^{4}$ Göttingen Academy of Sciences and Humanities, 37073 Göttingen, Germany

Corresponding author: mhopper@gwdg.de, Phone: +49-551-3933832

\section{Author contribution to the work:}

$\mathrm{MH}$ and $\mathrm{AK}$ designed the study. $\mathrm{MH}, \mathrm{AK}$ and TW and collected the samples. AK performed the experiments, examined data, interpreted the results and wrote the manuscript. KS performed the bioinformatics analysis for sequencing outcome. AR performed the chemical study of the samples. MH provided lab facilities, work collaboration, interpreted the results and corrected the manuscript. JR critically reviewed and corrected the manuscript. 


\title{
Article \\ Cyanobacterial Mats in Calcite-Precipitating Serpentinite-Hosted Alkaline Springs of the Voltri Massif, Italy
}

\author{
Aysha Kamran ${ }^{1}$, Kathrin Sauter ${ }^{1}$, Andreas Reimer ${ }^{2}$, Theresa Wacker ${ }^{1,3}$, Joachim Reitner ${ }^{2} \oplus$ and \\ Michael Hoppert ${ }^{1, *}$ \\ 1 Institute of Microbiology and Genetics, University of Göttingen, Grisebachstraße 8, \\ 37077 Göttingen, Germany; akamran@gwdg.de (A.K.); kathrin.sauter@stud.uni-goettingen.de (K.S.); \\ tw492@exeter.ac.uk (T.W.) \\ 2 Göttingen Centre of Geosciences, Georg-August-University Göttingen, 37077 Göttingen, Germany; \\ areimer@gwdg.de (A.R.); jreitne@gwdg.de (J.R.) \\ 3 Medical Research Council Centre for Medical Mycology (MRC CMM), University of Exeter, Geoffrey Pope \\ Building, Stocker Road, Exeter EX4 4QD, UK \\ * Correspondence: mhopper@gwdg.de; Tel.: +49-551-393-3832; Fax: +49-551-393-3808
}

Citation: Kamran, A.; Sauter, K.; Reimer, A.; Wacker, T.; Reitner, J.; Hoppert, M. Cyanobacterial Mats in Calcite-Precipitating Serpentinite-Hosted Alkaline Springs of the Voltri Massif, Italy.

Microorganisms 2021, 9, 62 .

https://doi.org/10.3390/

microorganisms 9010062

Received: 14 October 2020

Accepted: 15 December 2020

Published: 29 December 2020

Publisher's Note: MDPI stays neutral with regard to jurisdictional claims in published maps and institutional affiliations.

Copyright: (c) 2020 by the authors. Licensee MDPI, Basel, Switzerland. This article is an open access article distributed under the terms and conditions of the Creative Commons Attribution (CC BY) license (https: / / creativecommons.org / licenses/by/4.0/).

\begin{abstract}
Background: Microbial communities in terrestrial, calcifying high-alkaline springs are not well understood. In this study, we investigate the structure and composition of microbial mats in ultrabasic ( $\mathrm{pH}$ 10-12) serpentinite springs of the Voltri Massif (Italy). (2) Methods: Along with analysis of chemical and mineralogical parameters, environmental DNA was extracted and subjected to analysis of microbial communities based upon next-generation sequencing. (3) Results: Mineral precipitation and microbialite formation occurred, along with mat formation. Analysis of the serpentinite spring microbial community, based on Illumina sequencing of 16S rRNA amplicons, point to the relevance of alkaliphilic cyanobacteria, colonizing carbonate buildups. Cyanobacterial groups accounted for up to $45 \%$ of all retrieved sequences; $3-4$ taxa were dominant, belonging to the filamentous groups of Leptolyngbyaceae, Oscillatoriales, and Pseudanabaenaceae. The cyanobacterial community found at these sites is clearly distinct from creek water sediment, highlighting their specific adaptation to these environments.
\end{abstract}

Keywords: microbial diversity; cyanobacteria; serpentinite; alkaliphilic; carbonate

\section{Introduction}

Carbonates, formed both abiogenically or biogenically, are among the most abundant minerals, and are essential in the long-term global carbon cycle [1]. As dissolved ions, they are the most important parameters for ocean alkalinity [2]. Precipitation of a variety of carbonate mineral phases involving microorganisms has been reported under various environmental conditions [3-6]. Directed mineral precipitation (biomineralization) occurs through active biological control by an organism (mainly by eukaryotic algae and metazoans [7]). Cyanobacteria, in particular, are considered to be involved in carbonate precipitation within oceans, lakes, springs, caves, and even soil [8]. Active uptake of $\mathrm{CO}_{2}$, as $\mathrm{HCO}_{3}{ }^{-}$from an aqueous solution, results in a net increase in $\mathrm{OH}^{-}$ion concentration and $\mathrm{pH}$ increase in the environment. In the cell, $\mathrm{HCO}_{3}{ }^{-}$is converted to $\mathrm{CO}_{2}$ (for carbon dioxide fixation by the ribulose bisphosphate carboxylase enzyme) and a hydroxide ion, resulting in a shift to alkaline $\mathrm{pH}$ outside the cell. At elevated $\mathrm{pH}$, the equilibrium between carbonic acid, hydrogen carbonate, and bicarbonate is shifted to the deprotonated carbonate ion forms. Metal cations, mainly calcium and magnesium ions, combine with those ions and form precipitates of $\mathrm{Ca} / \mathrm{Mg}$-carbonates. Respiratory processes, however, invert the $\mathrm{pH}$ shift, and precipitated $\mathrm{CaCO}_{3}$ will be partly redissolved; by oxidation of organic compounds, $\mathrm{CO}_{2}$ is released. In aqueous solution, dissolved $\mathrm{CO}_{2}$ forms the weak acid $\mathrm{H}_{2} \mathrm{CO}_{3}$, resulting again in the formation of $\mathrm{H}^{+}$and $\mathrm{HCO}_{3}{ }^{-}$upon dissociation, which 
decreases $\mathrm{pH}$. When $\mathrm{CO}_{2}$ fixation and respiration are balanced against each other, considerable net carbonate precipitation may not be expected. In calcium-oversaturated systems, carbonate precipitation by biogenic shift of $\mathrm{pH}$ is negligible, but chemical precipitation becomes a challenge for microbial communities, due to rapid encasement by the mineral. As a countermeasure, (cyanobacterial) sheaths and/or capsular material precipitate calcium carbonate by attracting calcium ions to acidic groups of their exopolysaccharides (the carboxylic acid groups are mainly deprotonated at high $\mathrm{pH}$ ), and mineral precipitation is directed to sheaths or capsules [5,9]. In many carbonate-precipitating alkaline water bodies, cyanobacteria and other organisms are involved in formation of carbonate buildups $[4,5,10-12]$. Because of the overall high $\mathrm{pH}$, photosynthesis-driven $\mathrm{pH}$ shifts may be negligible, and carbonate precipitation at any nucleation site of a cell surface is inevitable. Serpentinization-driven high-alkaline springs may be considered as model systems for carbonate precipitation under participation of microorganisms. Frequently, travertine-like carbonate buildups form at the spring seeps [13-15]. The $\mathrm{pH}$ values are mostly higher (11-12) than in alkaline lakes (8-10) [16]. Because of low sodium concentrations in the alkaline springs, the environment does not correspond to soda lake conditions [15-17].

A number of these high-alkaline springs are located in the massifs of Voltri (Gruppo di Voltri), near Genoa. The massifs originate from Upper Jurassic oceanic crust belonging to the Piedmont-Ligurian Ocean of the Western Alpine ocean system [18,19]. Due to tectonic processes during the Eocene, ultramafic (peridotitic) rocks of the oceanic crust were subjected to metamorphosis, resulting in, e.g., eclogite and amphibolite facies [20]. After uplifting, the influence of meteoric water, and putatively seawater, under certain pressure and temperature conditions lead to conversion of olivine, pyroxenes, and amphiboles in the ultramafic rocks. As a result of this metamorphic process, serpentinite minerals are formed. The underlying process, termed serpentinization, comprises multiple reactions, involving hydrolyzation and oxidation of the starting minerals.

As one important reaction in this process, the olivine constituent forsterite is converted with water to serpentine (the name-giving mineral of the process) and brucite:

$$
2 \mathrm{Mg}_{2} \mathrm{SiO}_{4}+3 \mathrm{H}_{2} \mathrm{O} \rightarrow \mathrm{Mg}_{3} \mathrm{Si}_{2} \mathrm{O}_{5}(\mathrm{OH})_{4}+\mathrm{Mg}(\mathrm{OH})_{2}
$$

In the following, just some aspects about the complex geochemical processes are briefly mentioned, because their reaction products are potentially relevant for microbial processes.

The olivine constituent fayalite is oxidized to magnetite, which also results in release of molecular hydrogen:

$$
3 \mathrm{Fe}_{2} \mathrm{SiO}_{4}+2 \mathrm{H}_{2} \mathrm{O} \rightarrow 2 \mathrm{Fe}_{3} \mathrm{O}_{4}+3 \mathrm{SiO}_{2}+2 \mathrm{H}_{2}
$$

Molecular hydrogen reduces, in presence of catalysts (e.g., awaruite), carbon monoxide and carbon dioxide to short-chain hydrocarbons, most simply methane (e.g., [21]):

$$
4 \mathrm{H}_{2}+\mathrm{CO}_{2} \rightarrow \mathrm{CH}_{4}+2 \mathrm{H}_{2} \mathrm{O}
$$

Dissolution of forsterite and diopside produces calcium and hydroxide ions [22,23]:

$$
4 \mathrm{Mg}_{2} \mathrm{SiO}_{4}+\mathrm{CaMgSi}_{2} \mathrm{O}_{6}+7 \mathrm{H}_{2} \mathrm{O} \rightarrow 3 \mathrm{Mg}_{3} \mathrm{Si}_{2} \mathrm{O}_{5}(\mathrm{OH})_{4}+\mathrm{Ca}^{2+}{ }_{(\mathrm{aq})}+2 \mathrm{OH}^{-}(\mathrm{aq})
$$

Alkaline fluids pass through faults and fractures from their sources to the surface, where they emerge in springs. A microbial community of this serpentinizing environment is thought to be involved in the recycling of the released hydrogen and methane gas. Microorganisms from these communities have been recovered from borehole depths of up to $130 \mathrm{~m}$ below ground $[24,25]$. These subsurface microbial processes comprise the oxidation of hydrogen by hydrogenotrophic methanogenic archaea (resulting in the formation of methane), or by acetogenic bacteria (formation of acetate). Acetate may be utilized by acetotrophic methanogens; methane may be oxidized anaerobically in the deep subsurface, as long as appropriate electron acceptors (generally sulfate) are present. Analysis of the 
microbial community of the pristine spring water revealed the presence of hydrogen- and methane-consuming microbiota [15]. The anaerobic subsurface processes and aerobic respiration at the surface produce $\mathrm{CO}_{3}{ }^{2-}$ and $\mathrm{HCO}_{3}{ }^{-}$ions, which precipitate with divalent cations $\left(\mathrm{Ca}^{2+}, \mathrm{Mg}^{2+}\right)$ to form carbonate minerals (microbial carbonation [26]).

It is obvious, however, that small pools formed by the high-alkaline fluids are also exposed to the microbial communities of surrounding terrestrial and aquatic sources. The alkalitolerant organisms of these communities may be potential colonizers for the highly alkaline fluids. Our study focuses on presence and abundance of these organisms colonizing pools just next to the outflows of the high-alkaline springs. Inevitably, these organisms must cope with the rapid precipitation of carbonates in this environment.

\section{Materials and Methods}

\subsection{Sampling}

The samples were taken from Voltri Massif (Liguria, Italy), from two different locations at approximately $44^{\circ} 25^{\prime} 27.4^{\prime \prime} \mathrm{N}, 8^{\circ} 39^{\prime} 31.4^{\prime \prime} \mathrm{E}$ (Torrente Lerone, LER) and $44^{\circ} 26^{\prime} 43.3^{\prime \prime} \mathrm{N}$, $8^{\circ} 46^{\prime} 43.0^{\prime \prime} \mathrm{E}$ (Torrente Branega, BR). Several subsamples (LER subsamples: VE01-02.B, VE01-03.C, VE02-01.B, VE02-02.B, and BR subsamples: V04-01-BR1-1, V04-02-BR1-2a, and V04-03-BR1-3) were taken from carbonate crusts or bottom sediments of ponds. All samples were collected with sterile tools (bailer, scalpels, tubes). All samples were kept in a mobile freezing unit at $-20^{\circ} \mathrm{C}$, immediately after collecting, and were kept frozen until further processing.

For petrographic analysis, pieces of carbonate buildups and rocks were sampled with spatulas or hammer and chisel. Ophicalcite samples were taken from outcropping rocks $\left(44^{\circ} 11^{\prime} 29.1^{\prime \prime} \mathrm{N}, 9^{\circ} 35^{\prime} 42.9^{\prime \prime} \mathrm{E}\right.$; NE of Bonassola/La Spezia).

\subsection{Hydrochemical Analysis}

Physicochemical parameters of spring and pool waters were measured in field sites using a WTW Multi 3430 device equipped with a WTW Tetracon 925 conductivity probe, a Schott PT61 redox electrode, and a WTW Sentix 940 electrode for temperature and $\mathrm{pH}$ measurements (Xylem, Rye Brook, NY, USA), calibrated against standard pH buffers 7.010, 10.010, and 12.000 (HI6007, HI6010, and HI6012, Hanna Instruments, Woonsocket, RI, USA).

Spring and pool waters were collected without headspace in Schott Duran glass bottles (Schott, Mainz, Germany) and polyethylene bottles of varying size and were considered for the determination of anions, cations, nutrients, and total alkalinity (TA), as well as dissolved inorganic carbon (DIC). For cation analysis, a $50 \mathrm{~mL}$ aliquot was filtered through $0.7 \mu \mathrm{m}$ pore membrane filters and acidified with $100 \mu \mathrm{L} \mathrm{HNO}_{3}$ (Suprapur, Merck, Darmstadt, Germany). For determination of total sulfide $\left(\Sigma \mathrm{H}_{2} \mathrm{~S}\right)$, aliquots were fixed with $\mathrm{Zn}$-acetate. Samples were stored refrigerated in the dark until further processing. Total alkalinity was determined by acid-base titration immediately after sampling, using a hand-held titration device and $1.6 \mathrm{~N} \mathrm{H}_{2} \mathrm{SO}_{4}$ cartridges as titrant (Hach Lange $\mathrm{GmbH}$, Düsseldorf, Germany).

Main cations $\left(\mathrm{Li}^{+}, \mathrm{Na}^{+}, \mathrm{K}^{+}, \mathrm{Mg}^{2+}, \mathrm{Ca}^{2+}, \mathrm{Sr}^{2+}\right)$ and anions $\left(\mathrm{F}^{-}, \mathrm{Cl}^{-}, \mathrm{Br}^{-}, \mathrm{NO}_{3}{ }^{-}, \mathrm{SO}_{4}{ }^{2-}\right)$ were analyzed by ion chromatography with non-suppressed and suppressed conductivity detection (Metrohm 820 IC, Metrohm 883 Basic IC; Metrohm, Herisau), respectively. Concentrations of $\mathrm{NH}_{4+}, \mathrm{NO}_{2-}, \mathrm{PO}_{4}{ }^{3-}, \Sigma \mathrm{H}_{2} \mathrm{~S}$, and dissolved silica were determined photometrically according to [27], using an SI Analytics Uviline 9400 spectrophotometer. Dissolved inorganic carbon was determined with a TOC-L CPH analyzer (Shimadzu, Kyoto, Japan).

The PHREEQC software (version 3.5.0, 2019 [28]), using the phreeqc.dat and wateqf4.dat databases, was applied for calculation of ion activities, $\mathrm{pCO}_{2}$ (partial pressure of $\mathrm{CO}_{2}$ ) of samples, and mineral saturation states. Saturation is given as $\mathrm{SI}=\log (\mathrm{IAP} / \mathrm{KSo}$ ), where IAP denotes ion activity product and KSo solubility product of the mineral phase. 


\subsection{Microscopic Analysis and Petrography}

Petrographic thin sections of approximately 30-60 $\mu \mathrm{m}$ in thickness were essentially performed according to [29]. Light microscopic analysis of sections was conducted with a Zeiss SteREO Discovery V8 stereomicroscope (transmitted and reflected light) linked to an AxioCam MRc 5-megapixel camera (Zeiss, Göttingen, Germany).

Light microscopy of cyanobacteria was performed using a Motic BA310E microscope (Motic GmbH, Wetzlar, Germany) with phase contrast optics and equipped with a Color view III camera (Motic $\mathrm{GmbH}$ ). Micrographs were processed using the cell D image software (Motic $\mathrm{GmbH}$ ). Raman microscopy in conjunction with Raman spectrometric analysis of petrographic sections was performed as described [30].

For scanning electron microscopy, samples of about $1 \mathrm{~cm}^{3}$ were dehydrated in an ascending ethanol series (15\% to $99 \%)$, mounted on SEM sample holders, and sputtered with Au-Pd (7.3 nm for $120 \mathrm{~s})$. Field emission scanning electron microscopy (FE-SEM) was performed using a Carl Zeiss LEO 1530 Gemini system (Zeiss, Oberkochen, Germany).

Stable isotope measurements $\left({ }^{12} \mathrm{C},{ }^{13} \mathrm{C},{ }^{16} \mathrm{O},{ }^{18} \mathrm{O}\right)$ on carbonates were conducted at the Department of Isotope Geology (Göttingen Centre of Geosciences) using a Thermo KIEL VI/Finnigan Delta+ gas mass spectrometer (Thermo Fisher Scientific, Waltham, Mass., USA). A total of $100 \mathrm{mg}$ of powdered whole rock material was analyzed, respectively. Data are expressed as $\delta$ value relative to Vienna Pee Dee Belemnite (V-PDB). Values reported here have an analytical error of $<0.2 \%$.

\subsection{DNA Extraction}

DNA was extracted from $0.35 \mathrm{~g}$ of a single sample with the Power Soil DNA isolation kit (Qiagen, Hilden, Germany), following the manufacturers protocol. After extraction, agarose gel electrophoresis was used to estimate the approximate size distribution of the extracted DNA from each sample ( $1 \mathrm{~kb}$ DNA size standard ladder, $1 \%$, $w / v$, agarose; Thermo Fisher Scientific). Concentration of DNA from each sample was estimated in a Nanodrop spectrophotometer (Thermo Fisher Scientific). Polymerase chain reaction (PCR)-based amplification of the V3 and V4 region of the bacterial $16 \mathrm{~S}$ rRNA was performed in triplicates from each sample by thermal cycler processing. For the appropriateness of the amplicons for Illumina MiSeq sequencing (Illumina, San Diego, CA, USA), primers were additionally linked to the overhang adapter sequences (16S amplicon PCR forward primer $=5^{\prime}-\mathrm{TCG}$ TCG GCA GCG TCA GAT GTG TAT AAG AGA CAG CCT ACG GGN GGC WGC WGC AG-3'; 16S amplicon PCR reverse primer $=5^{\prime}$-GTC TCG TGG GCT CGG AGA TGT GTA TAA GAG ACA GGA CTA CHV GGG TAT CTA ATC C-3'; adaptor sequences according to the manufacturers note, primers for bacterial 16S rRNA genes according to [31]). Master Mix was prepared according to [31], with minor modifications: $\mathrm{MgCl}_{2} 25 \mathrm{mM}(0.15 \mu \mathrm{L})$, DMSO $5 \%(2.5 \mu \mathrm{L}), 5 \times$ Phusion GC Buffer $(10 \mu \mathrm{L})$, dNTPs $10 \mathrm{mM}(1 \mu \mathrm{L})$, reverse and forward primer (1:10 dilution), $2 \mathrm{U} / \mu \mathrm{L}$ Phusion HF DNA polymerase $(0.5 \mu \mathrm{L})$, and template DNA $25 \mathrm{ng}(1 \mu \mathrm{L})$ made up to the final volume of $50 \mu \mathrm{L}$ with double-distilled nuclease-free water (Phusion GC buffer and polymerase: Thermofisher Scientific). The following thermal cycler program was used: initial denaturation at $98^{\circ} \mathrm{C}$ for $1 \mathrm{~min}, 25$ cycles at $98^{\circ} \mathrm{C}$ for $45 \mathrm{~s}, 60^{\circ} \mathrm{C}$ for $45 \mathrm{~s}, 72{ }^{\circ} \mathrm{C}$ for $30 \mathrm{~s}$, and, finally, one cycle at $72{ }^{\circ} \mathrm{C}$ for $5 \mathrm{~min}$.

For gel electrophoresis, $1 \mu \mathrm{L}$ HDGreen stain (INTAS, Göttingen, Germany) was mixed with $3 \mu \mathrm{L}$ of the PCR product solution and separated with a $1.3 \%(w / v)$ agarose gel in a Tris-acetate-EDTA-buffer (TAE)-system/ [32], while a $1 \mathrm{~kb}$ DNA ladder (Thermofisher Scientific) was used as size standard. A NanoDrop photometer (Thermofisher Scientific) was used to quantify the DNA in the reaction mixture. The GeneRead Size Selection Kit (Qiagen, Venlo, The Netherlands) was used for the selection of target amplicons ( $500 \mathrm{bp})$. An Illumina MiSeq desktop sequencer (Illumina, San Diego, CA) was used for the sequencing, employing the MiSeq Reagent Kit v3 $(2 \times 300$ bp paired-end reads; Illumina). 


\subsection{Sequence Data Processing}

Paired-end sequencing of amplicons and processing of sequencing data were carried out in the Göttingen Genomics Laboratory (Göttingen, Germany). The software FastQC v0.11.8 [33] was used to check and verify the paired-end reads. After merging the sequences, short reads (less than 305 base pairs) and those with unidentifiable bases were eliminated with PANDAseq v2.11 [34] using the PEAR algorithm v0.9.8 [35]. Forward and reverse primer sequences were eliminated using cutadapt v1.15 [36]. The amplicon sequences were processed with QIIME 1.9.1 [37]. The sequences were dereplicated and verified for chimeric sequences (de novo). The sequences were clustered into operational taxonomic units (OTUs) with 97\% identity. The taxonomic classification of the OTU sequences was also carried out with QIIME 1.9.1 against the SILVA database 132 using the assignment method [38], with chloroplasts, extrinsic domains, and unclassified OTUs being eliminated from the dataset. Sample comparisons were performed at the same surveying effort, utilizing the lowest number of sequences by random subsampling. All sequences are available via the Biosample database of the NCBI (National Center for Biotechnology Information, Bethesda, MD, USA) under Bioproject accession No. PRJNA685937.

Results were displayed as bar charts based upon the summarized OTU tables. Alpha diversity was expressed as rarefaction curve (number of observed species plotted versus number of sequences retrieved from a sample), as a function of the QIIME pipeline. To visualize the microbial composition between samples by principal coordinates analysis ( $\mathrm{PCOA})$, a square matrix expressing the dissimilarity between every pair of samples [39] was calculated in QIIME and rendered by EMPeror (integrated with QIIME [40]) for graphic visualization. Venn Diagrams were plotted based upon the BioVenn application [41].

\section{Results}

\subsection{Hydrochemistry, Carbonate Fabrics and Isotopic Record}

All spring water bodies in the Torrente Branega/Torrente Lerone of the Voltri Massif area show extremely high $\mathrm{pH}$ values, mostly above 11 (Table 1, Table S1), and exhibit low total alkalinity (on average 1.75 meq L $\mathrm{L}^{-1}$ for Torrente Lerone sites and $2.5 \mathrm{meq} \mathrm{\textrm {L } ^ { - 1 }}$ for Torrente Branega sites). All are oversaturated with respect to calcium carbonate. In both sites, dissolved inorganic carbon is low $\left(1.2-1.3 \mathrm{mg} \mathrm{L}^{-1}\right)$. The redox potentials are considerably lower than in creek water, in particular in all samples taken from the Torrente Lerone sites. Generally, concentration of macroelements relevant for microbial growth (nitrate/ammonium, phosphate) are low, i.e., the sites are highly alkaline, calcite-precipitating, oligotrophic water bodies. At all springs, carbonate buildups are formed. The carbonates frequently form cascade-shaped crusts at sites where spring water trickles over rock surfaces (Figure 1a,b). Small pools form in depressions in or between rocks; they are calm water bodies with no significant currents. Pool water appears clear; the precipitated calcite particles form a sediment body on the bottom of the pools. Samples were all taken from more or less consolidated calcitic crusts and the sediment of the high-alkaline pools (Figure 1a-c). Figure 1d,e depict the sampling sites and typical features of representative samples.

Thin sections of consolidated travertine-like carbonates, perpendicular to the surface (cf. Figure 2a,b) frequently show a stromatolitic fabric. The structure is characterized by 1-2 mm light-yellow calcite crusts, which alternate with light- to dark-grey calcites and micritic areas (Figure $2 b-d$ ). The carbonate buildups exhibit a multitude of open pores, characteristic for a fenestral (birdseye) fabric. Calcites contain diatom frustules and other inclusions of putatively microbial origin, like tiny filamentous structures (Figure 2c,g,h). UV excitation reveals various intensities of blue fluorescence, indicative of the presence of organic material (Figure 2e,f; cf. [42]. Generally, Raman spectroscopy (not depicted) showed only low organic contents. Occasionally pyrite crystals are associated with the calcites, which show high contents of organic carbon. 
Table 1. Selected water chemistry parameters of the sampling sites (see Table S1 for a complete dataset from alkaline springs), Ler: Torrente Lerone samples; Br: Torrente Branega samples.

\begin{tabular}{cccc}
\hline Parameter & Ler & Br & Creek Water Reference (Br) \\
\hline $\mathrm{pH}$ & $11.2-11.3$ & $11.2-11.5$ & 8.45 \\
\hline $\mathrm{Eh}$ & $-60 \mathrm{mV}$ & $+180-+230 \mathrm{mV}$ & $+370 \mathrm{mV}$ \\
\hline $\mathrm{Ca}^{2+}$ & $34-43 \mathrm{mg} \mathrm{L}^{-1}$ & $33-47 \mathrm{mg} \mathrm{L}^{-1}$ & $19 \mathrm{mg} \mathrm{L}^{-1}$ \\
\hline $\mathrm{Na}^{+}$ & $8-10 \mathrm{mg} \mathrm{L}^{-1}$ & $23-25 \mathrm{mg} \mathrm{L}^{-1}$ & $14 \mathrm{mg} \mathrm{L}^{-1}$ \\
\hline $\mathrm{K}^{+}$ & $0.7-3.1 \mathrm{mg} \mathrm{L}^{-1}$ & $2.8-3.1 \mathrm{mg} \mathrm{L}^{-1}$ & $1.3 \mathrm{mg} \mathrm{L}^{-1}$ \\
\hline $\mathrm{SO}_{4}{ }^{2-}$ & $2.0-2.4 \mathrm{mg} \mathrm{L}^{-1}$ & $0.1-0.5 \mathrm{mg} \mathrm{L}^{-1}$ & $5.9 \mathrm{mg} \mathrm{L}^{-1}$ \\
\hline $\mathrm{NO}_{3}{ }^{-}$ & $0.005-0.014 \mathrm{mg} \mathrm{L}^{-1}$ & $0.005-0.030 \mathrm{mg} \mathrm{L}^{-1}$ & $1.5 \mathrm{mg} \mathrm{L}^{-1}$ \\
\hline $\mathrm{NH}_{4}{ }^{+}$ & $0.03-0.04 \mathrm{mg} \mathrm{L}^{-1}$ & $0.03-0.12 \mathrm{mg} \mathrm{L}^{-1}$ & $0.01 \mathrm{mg} \mathrm{L}^{-1}$ \\
\hline $\mathrm{H}_{2} \mathrm{~S}$ & $0.2-0.7 \mathrm{mg} \mathrm{L}^{-1}$ & $0.006-0.05 \mathrm{mg} \mathrm{L}^{-1}$ & $\mathrm{n} / \mathrm{a}$ \\
\hline
\end{tabular}
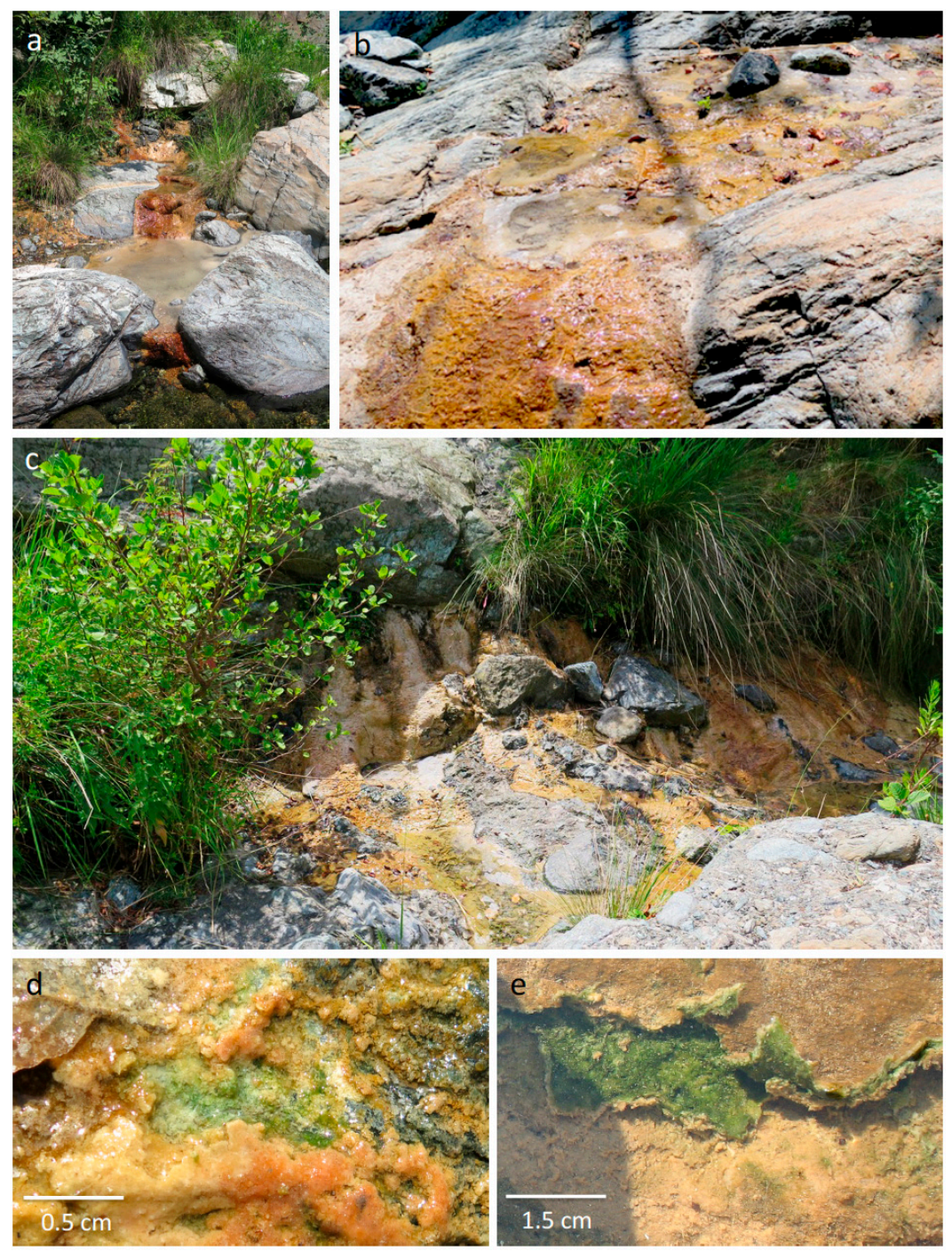

Figure 1. Cyanobacterial biofilms in sampling sites: (a,b) Torrente Leorne and (c) Torrente Branega alkaline pools. (d,e) Thin greenish layers, dominated by cyanobacteria, are situated below calcitic crusts. 

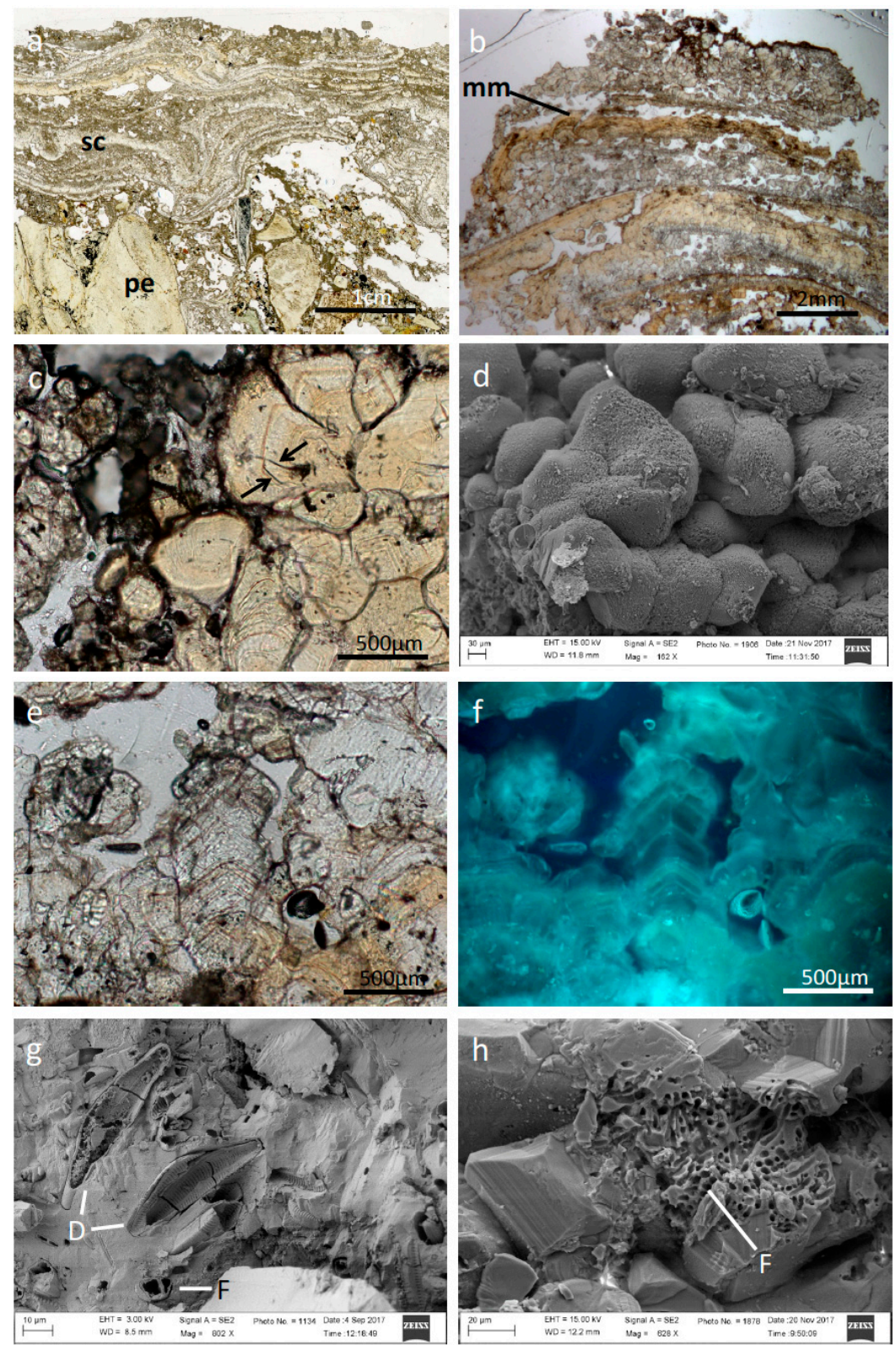

Figure 2. Microstructure of representative carbonate buildups from Torrente Lerone: (a) Travertinelike spring carbonate buildups: stromatolitic crusts (sc) overgrowing ultramafic rock pebbles (pe). (b) Detailed view of a stromatolitic crust exhibiting mineralized microbial mats (mm, light yellow crusts) alternating with grey calcites and micritic portions. (c) Magnified view of the light-yellow anhedral calcites showing entrapped microbial remains (arrows). (d) Field emission electron microscopic (FE-SEM) view of the light-yellow calcites. (e) Grey-white scalenohedral calcite with growth laminae. (f) Same specimen as (e) under UV-fluorescence excitation. Blue fluorescence is caused by intracrystalline organic matter. (g) FE-SEM view of the grey-white calcites. Frustules of pennate diatoms (D) and holes as remains of microbial filaments (cross sections; F) are visible. (h) FE-SEM view of the light-yellow calcites with remains of filamentous microbes $(\mathrm{F})$.

In samples from Torrente Branega (Figure 3), stromatolitic crusts are not clearly developed (Figure 3a); the partly anhedral shape of the calcite crystals, however, corresponds to the observations for specimens from Torrente Lerone sites. In the Branega carbonates, entrapped microbial cells are more abundant (Figure 3a-d); pennate diatoms and filamentous microbial remains are observable. The open pore calcitic carbonate system also exhibits fenestral fabric. 

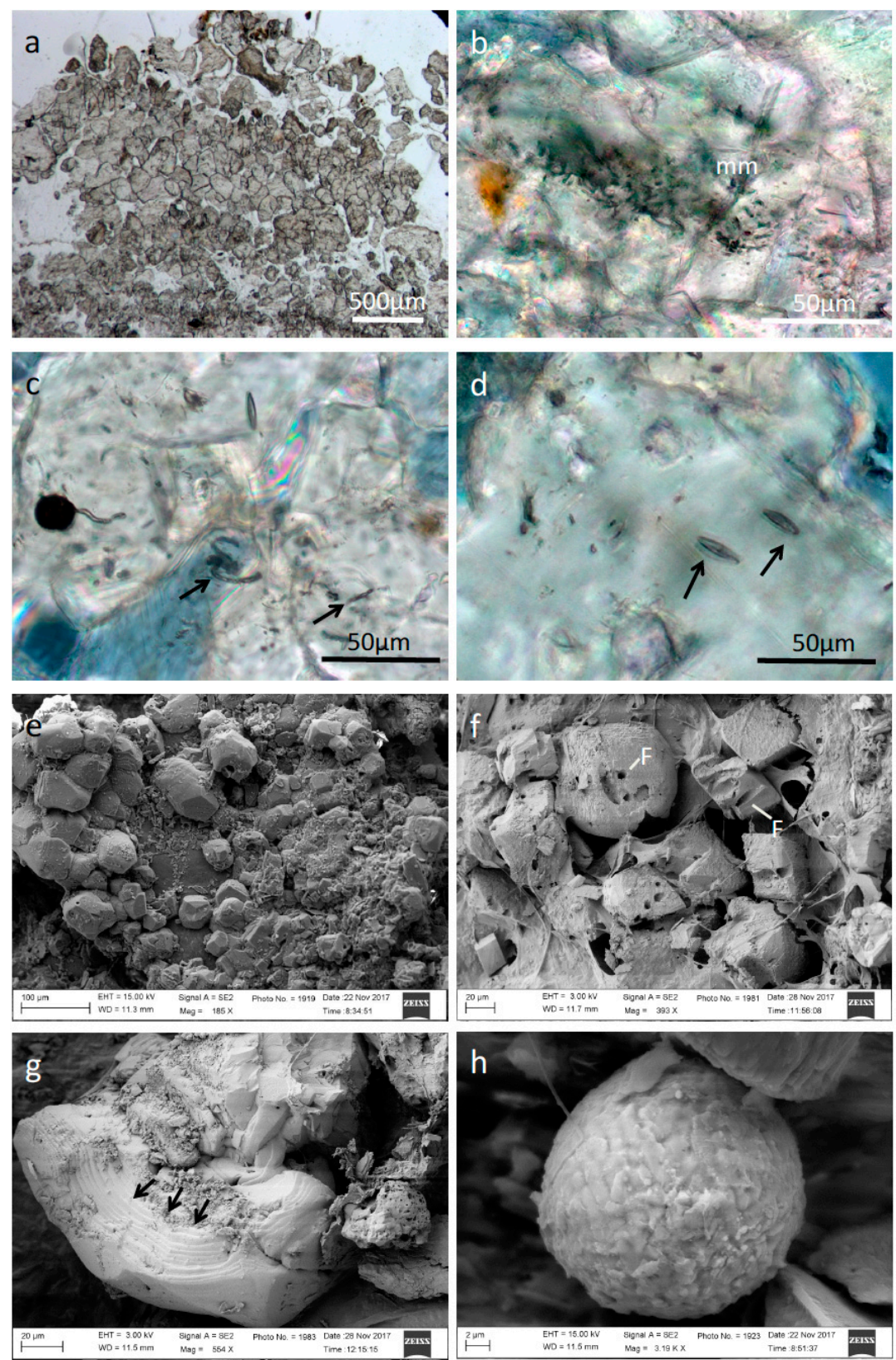

Figure 3. Microstructure of representative carbonate buildups from Torrente Branega: (a) Aggregates of grey calcites. Stromatolitic crusts are just weakly developed. (b) Microbial mat remains (mm) entrapped in calcites. (c) Filamentous microbial remains (arrows) within calcite crystals. (d) Pennate diatoms entrapped within calcite (arrows). (e) FE-SEM picture of newly formed anhedral calcite crystals. (f) FE-SEM picture of nearly euhedral calcite crystals exhibiting holes of formerly filamentous microbes and remains. The crystals are covered by dehydrated exopolymeric substances (EPS). (g) FE-SEM picture of an anhedral calcite crystal showing "stromatolitic" growth pattern (arrows). (h) FE-SEM picture of a framboidal pyrite globule associated with calcites.

In order to gain more insight into the origin of the carbonate constituents, stable $\delta^{13} \mathrm{C}$ and $\delta^{18} \mathrm{O}$ isotopes of carbonate buildups from Torrente Lerone and Torrente Branega, as well as ophicalcites from a nearby abandoned quarry, were analyzed. In Torrente Lerone carbonates, the $\delta^{13} \mathrm{C}_{\mathrm{CaCO} 3}$ values ranged from $-24 \%$ to $-11 \% ; \delta^{18} \mathrm{O}_{\mathrm{CaCO} 3}$ values ranged from $-19 \%$ to-9\%. Most negative values were measured for travertine-like carbonates close to the spring site; with increasing distance from the spring, the isotopic mixtures became less depleted. 
In the Torrente Branega site, data differ from the Lerone locality. The measured $\delta^{13} \mathrm{C}$ values were close to $0 \%$, up to $+0.6 \%$. $\delta^{18} \mathrm{O}$ values ranged between $-20 \%$ and $-26 \%$. For samples at different distances to the spring, no trend was visible. These data exhibit similarity with the cemented carbonate fractures within so-called ophicalcites NE of Bonassola/La Spezia [43]; in many active and abandoned quarries, the serpentinized ultramafic rocks are exposed. They are characterized by abundant carbonate fractures due to strong hydrofracturing during serpentinization. Samples taken from these ophicalcites showed $\delta^{13} \mathrm{C}$ values around $+2 \%$ and $\delta^{18} \mathrm{O}$ values between $-8 \%$ and $-16 \%$.

\subsection{Microbial Diversity}

Green layers of photosynthetic organisms were located below the partially consolidated thin crusts of white and brown precipitates of calcite (Figure 1d,e). Light microscopy reveals bundles of filaments, appearing similar to cyanobacterial morphotypes (Figure 4a), but also empty sheaths of cyanobacterial cells, with small rod-like bacterial morphotypes attached to these sheaths. Mineral particles are attached to these filaments, but do not form tight crusts (Figure 4b).
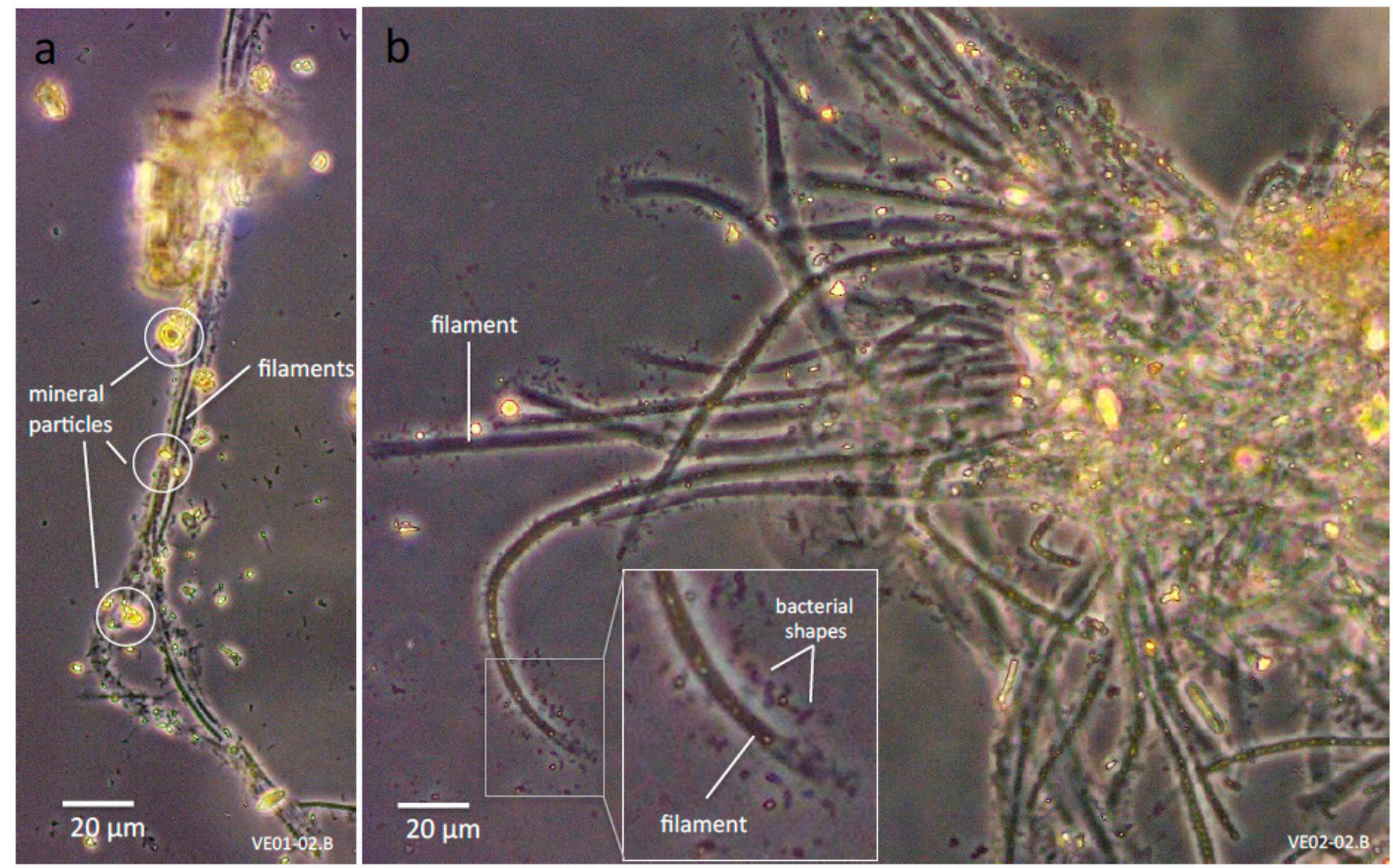

Figure 4. Representative samples depicting filamentous cyanobacterial morphotypes intermixed with calcitic precipitates: (a) Sample VE01-02.B; mineral particles attached along cyanobacterial filaments. (b) Sample VE02-02.B; multiple bacterial morphotypes (inset) adjacent to a filament.

The operational taxonomic units (OTUs) above $2 \%$ relative abundance, at least in one of the samples, is shown in Figure 5. Taxa of less-abundant cyanobacteria, not shown in Figure 5, are depicted in Figure 6. Rarefaction curves for all OTUs (Figure S2) do not reach a plateau, but still show considerable differences in expected species numbers per sample; these are considerably higher in the (non-alkaline) creek water sample (reference), when compared to samples from alkaline pools. Cyanobacteria reach up to $45 \%$ of all retrieved OTUs in some samples, with $24 \%+/-5 \%$ in Torrente Branega samples and $38 \%+/-5 \%$ in Torrente Lerone samples. 


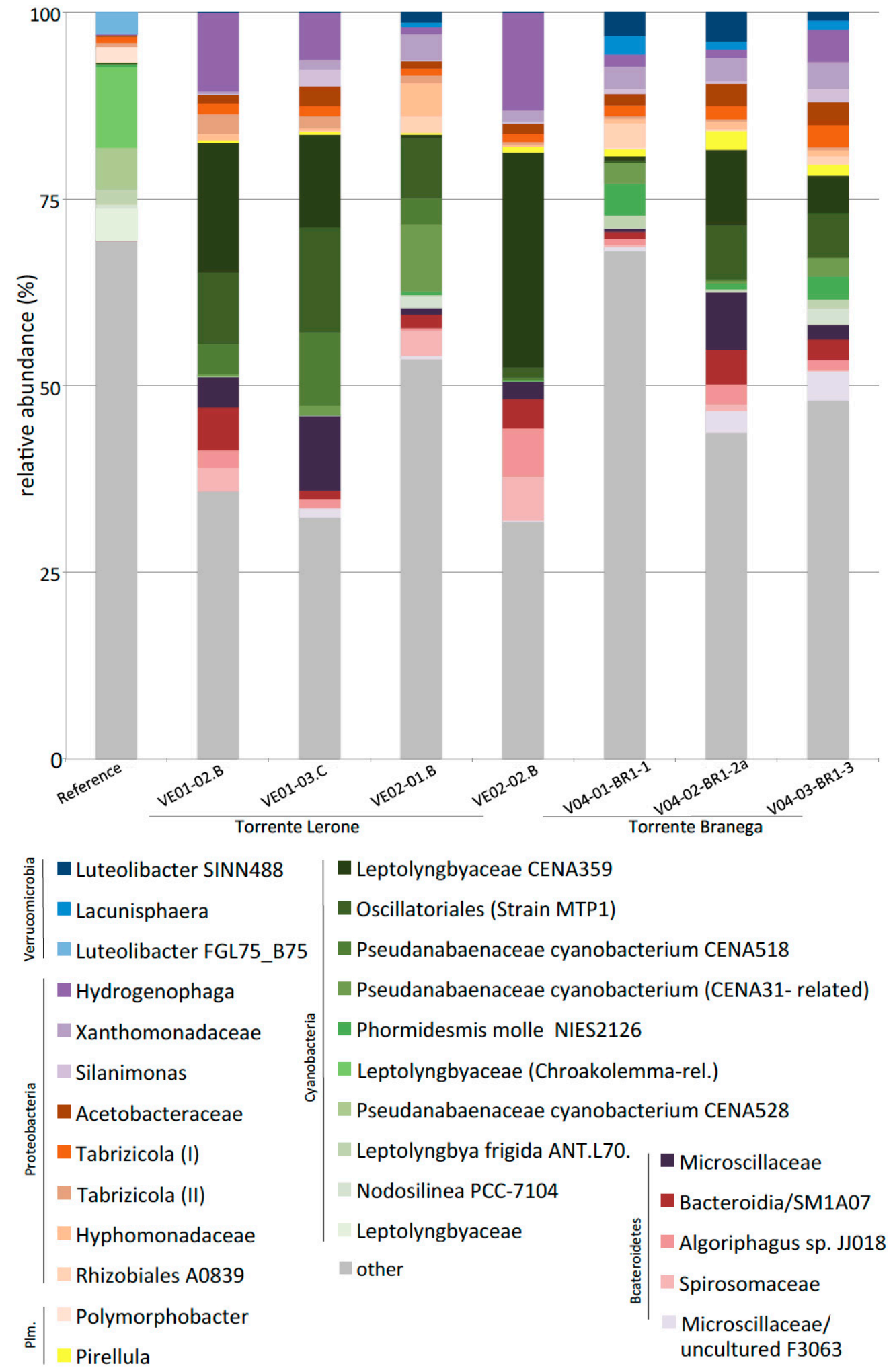

Figure 5. Bar charts showing the most abundant bacterial groups retrieved from all sites (reference: Table 1. VE02, Torrente Lerone spring site; V04, Torrente Branega spring sites). 


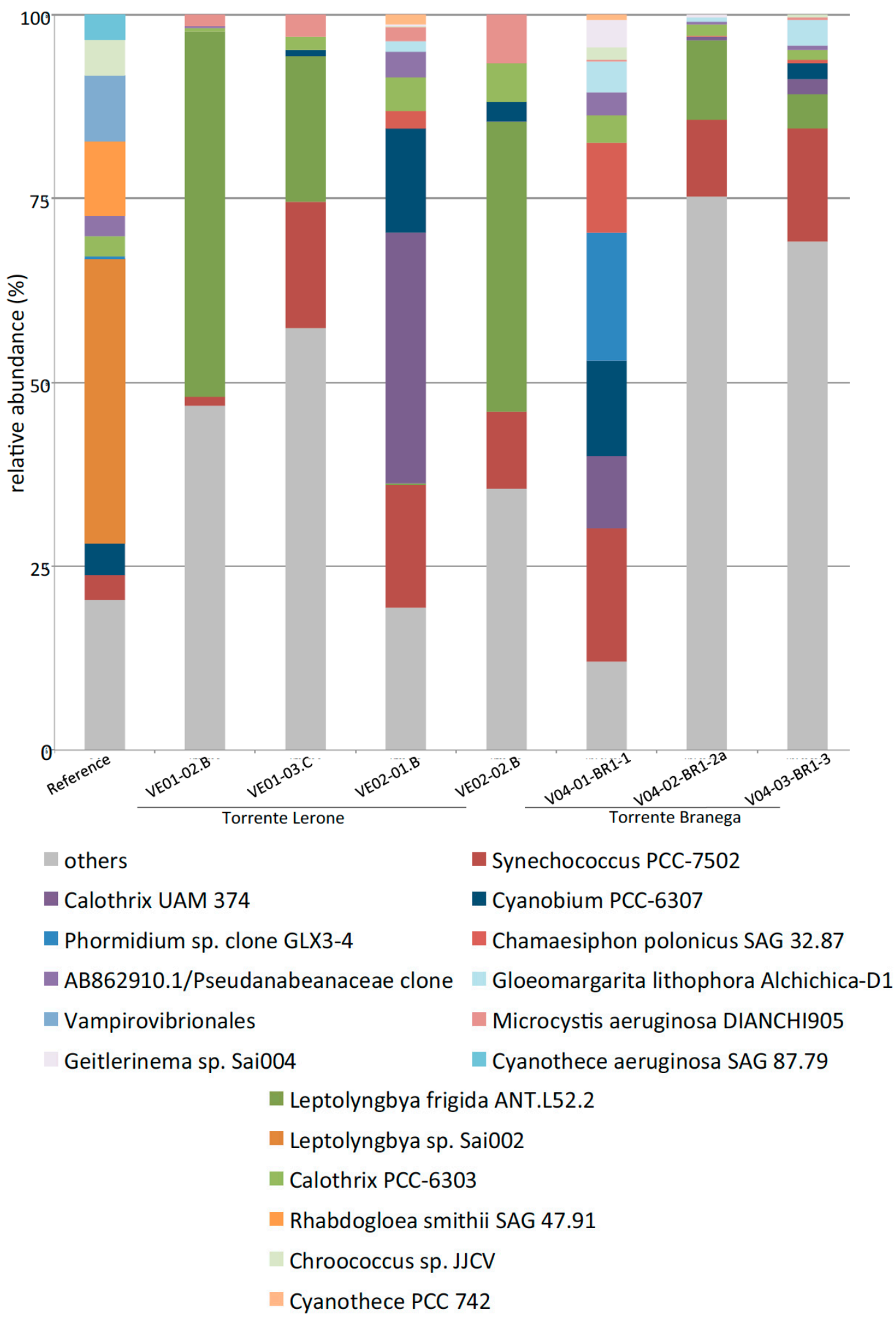

Figure 6. Bar charts showing the minor cyanobacterial groups retrieved from all sites (reference: Torrente Branega creek water sediment; VE01, VE02, Torrente Lerone spring sites; V04, Torrente Branega spring sites).

The weighted (Figure 7) and unweighted (not depicted) PCoA plots show that the beta diversities from spring sites form two separate clusters. All Torrente Branega samples form a cluster, along with one of the Torrente Lerone samples. Apparently the relative abundance of the dominant taxa of sample VE02-01.B is similar to the respective community 
of Torrente Branega samples (cf. Figure 5), though environmental data (cf. Table S1) of the VE02-01.B sampling site do not greatly differ from those of the other Torrente Lerone sites. All other samples from Torrente Lerone form a separate, broader cluster. All communities are clearly distinct from creek water sediment, taken from Torrente Branega as a reference.

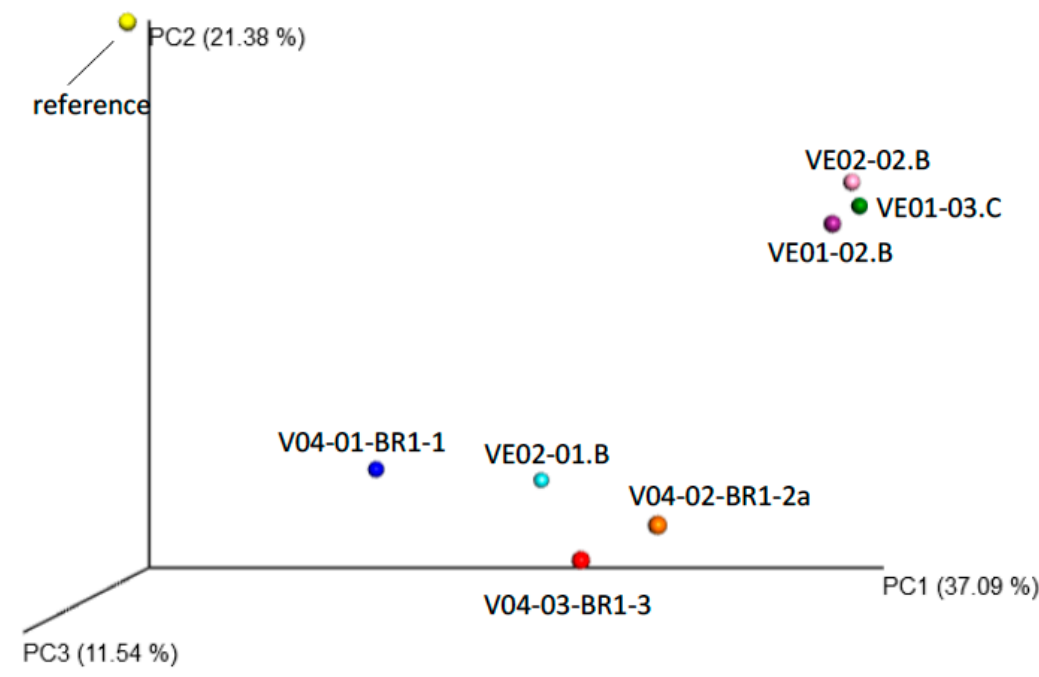

\section{Torrente Lerone}

VE01-02.B

VE01-03.C

VE02-01.B

VE02-02.B
Torrente Branega

V04-01-BR1-1

V04-02-BR1-2a

V04-03-BR1-3

Figure 7. Unweighted principal coordinates analysis (PCoA) plot, depicting all samples as indicated.

Venn diagrams illustrate the overlap in the cyanobacterial communities of both sites (Torrente Lerone, Torrente Branega), compared with the reference (Figure 8). In alkaline spring samples, few cyanobacterial groups are highly abundant (in this case, taxa represented by more than $2 \%$ of all OTUs in one or more of the samples; see Figure 5); they are different from the abundant groups detected in creek water sediment samples. The composition of the cyanobacterial communities in all alkaline spring samples is quite similar, with two dominating OTUs in most samples, related to the Leptolyngbyales strain CENA359 (up to 30\% of all retrieved OTUs) and the Oscillatoriales strain MPT1 (up to $14 \%$ ). Other frequent cyanobacteria are the Pseudanabenaceae cyanobacterium CENA518 and CENA319-related Phormidiaceae, being abundant just in some of the alkaline spring samples. A Chroakolemma-related Leptolyngbyaceae cyanobacterium and the Pseudanabaenaceae cyanobacterium CENA528 dominates the cyanobacterial community in creek water, whereas a Leptolyngbya frigida ANT.L70.1-related organism is present, in lower amounts, both in freshwater and in some of the alkaline spring samples. Another Leptolyngbya-related OTU (Leptolyngbya frigida ANT.L52.2) is abundant in all samples from alkaline springs. Among low abundant cyanobacterial taxa (Figures 6 and 8b) a Synechococcus PCC-7502related OTU was retrieved from all samples. This is the only taxon present in all alkaline spring samples, as well as creek water samples. Other taxa (Calothrix PCC-6303-related, Pseudanabaenaceae-rel.) are not present in all samples, but occur in some of the alkaline spring samples, and in creek water. Samples VE02-02.B and V04-01-BR1-1 exhibited a higher diversity among the rare cyanobacterial taxa than the other samples. 

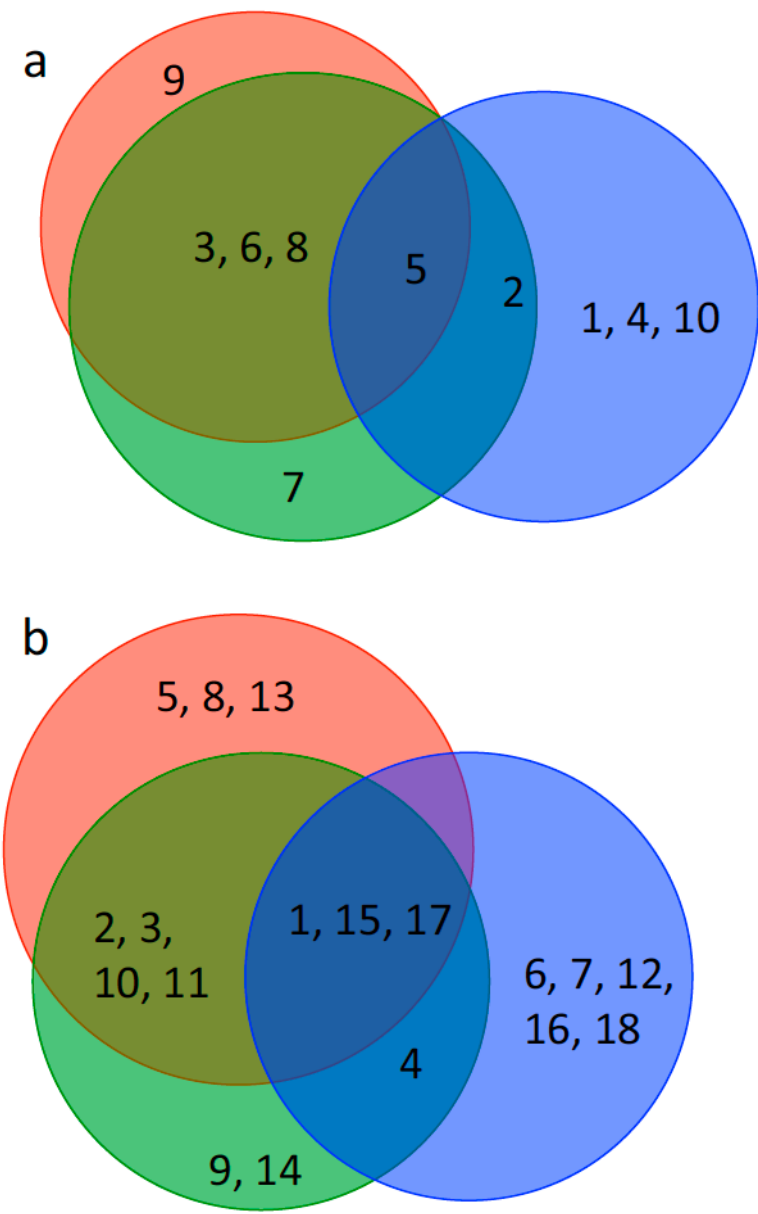

blue: reference green: Torrente Branega sites red: Torrente Lerone sites
1 Leptolyngbyaceae sp.

2 Leptolyngbya frigida ANT.L70.1

3 Leptolyngbyaceae CENA359

4 Leptolyngbyaceae (Chroakolemma-rel.)

5 Nodosilinea PCC-7104

6 Oscillatoriales (Strain MTP1)

7 Phormidesmis molle NIES2126

8 Pseudanabaenaceae cyanobacterium (CENA319 related)

9 Pseudanabaenaceae cyanobacterium CENA518

10 Pseudanabaenaceae cyanobacterium CENA528

1 Calothrix PCC-6303

2 Calothrix UAM 374

3 Chamaesiphon polonicus SAG 32.87

4 Chroococcus sp. JJCV

5 Cyanobium PCC-6307-related (A)

6 Cyanobium PCC-6307-related (B)

7 Cyanothece aeruginosa SAG 87.79

8 Cyanothece PCC 742

9 Geitlerinema sp. Sai004

10 Gloeomargarita lithophora Alchichica-D1

11 Leptolyngbya frigida ANT.L52.2

12 Leptolyngbya sp. Sai002

13 Microcystis aeruginosa DIANCHI905

14 Phormidium sp. clone GLX3-4

15 Pseudanabaeanaceae clone

16 Rhabdogloea smithii SAG 47.91

17 Synechococcus PCC-7502

18 Vampirovibrionales

Figure 8. Venn diagrams for (a) high abundant (a) and minor (b) cyanobacterial groups in samples from alkaline springs and creek water, as indicated.

Other abundant bacterial phyla are Proteobacteria (28-38\% of all OTUs), Bacteroidetes (15-25\% of all OTUs), Planctomycetes (2-15\%), and Verrucomicrobia (1-8\%). In the following, some of the abundant genera are presented. Among other bacteria (Figure 5), a betaproteobacterial OTU related to Hydrogenophaga is of highest abundance in most of the samples, but is missing in the creek water sample. In a similar way, two Xanthomonadaceae, one identified as Silanimonas-related, are abundant in the alkaline springs, but absent in creek water. An Acetobacteraceae bacterium (related to Rhodovarius and Sediminicoccus rosea) is well present in all alkaline spring samples, but is also represented by few sequence reads in creek water. Two Tabrizicola-related OTUs are also present in all alkaline and creek water samples. Other, non-cyanobacterial taxa are either present in alkaline springs but not in creek water (e.g., Hyphomonadaceae, Rhizobiales A0839, Pirellula), or in creek water with low or no occurrence in alkaline springs (Polymorphobacter).

\section{Discussion}

Microbial ecosystems associated with serpentinization have been reported for seafloor hydrothermal chimneys (for instance [44,45]), alkaline springs on land [46-48], and wells drilled into serpentinizing rocks [25,49-51]. Systems exposed to sunlight, such as the alkaline springs and associated pools in this study, should be expected to develop stable microbial communities based on phototrophic primary producers. Four OTUs (A: Oscil- 
latoriales/Strain MTP1-related, B: Pseudanabaenaceae cyanobacterium CENA518-related, C: Leptolyngbyaceae CENA359-related, D: Pseudanabaenaceae cyanobacterium CENA319-related) are most widespread in alkaline samples and are of highest abundance. Related taxa have been already described for alkaline water bodies, including a serpentinizing ecosystem (OTUs B, D) [47,52]. One was described as extremophilic (thermophilic, heavy metal resistant: OTU A from an enrichment culture of a sample obtained at a thermal source at Chalk Creek, Colorado [53]), or related to carbonate precipitation (OTU C) [54]. Two OTUs are exclusively retrieved from non-alkaline creek water (Chroakolemma-related Leptolyngbyaceae, Pseudanabeaceae Cyanobacterium CENA528). It may be surprising that the latter has been described as an isolate from Brazilian alkaline lakes [52], however, since the isolate is able to grow on a standard growth medium at pH 7.8 [55], it may not necessarily be an obligate alkaliphilic strain. Three OTUs (related to Nodosilinea PCC-7104, Leptolyngbya frigida ANT.L70.1, or Phormidesmis molle NIES2126) were retrieved from freshwater and alkaline spring sites, accounting for a broad ecological amplitude of these organisms.

A look at cyanobacterial OTUs being present in low abundance (less than $2 \%$, Figure 6) revealed, in a similar way to the abundant taxa, differences between the alkaline and the creek community, but also some more shared taxa (Figure 8b). Synechococcus PCC-7502 is present in all samples, whereas Leptolyngbya frigida ANT.L52.2 just occurs in alkaline spring samples. Other serpentinizing springs may not necessarily host similar or identical cyanobacterial taxa. The dominant OTUs from an alkaline spring system within the Del Puerto ophiolite [56] are mainly Leptolyngbya-related OTUs without closer relationship to the OTUs gained in this study. This may be due to the fact that the cyanobacterial mats were retrieved from water bodes at $\mathrm{pH}$ 9, i.e., at considerably lower $\mathrm{pH}$. From a serpentinizing spring site at the Chimaera ophiolite (Turkey), cyanobacterial OTUs in low amounts (up to $3.4 \%$ of all retrieved sequences) were obtained, with members of the Pseudanabaenales order at high abundance among cyanobacteria in all samples, which corresponds to samples from the Voltri sites. Generally, in all Chimaera seep sites, discharge is very low, and the formation of pools could not be observed. This may be a reason for the overall low abundance of cyanobacteria $[57,58]$.

In all alkaline spring samples from Torrente Lerone and Torrente Branega, cyanobacterial filaments were either layered below consolidated carbonate crusts, and appeared as microstromatolite-like structures, or they were covered by dispersed, loosely-attached calcite particles (cf. [59]). In any case, cyanobacterial biofilms were not exposed at a surface, but below a calcite layer (Figure 1d,e), which suggests a similar lifestyle as known from endolithic communities (e.g., [60]), putatively in order to avoid exposure to highest light intensities at the sediment surface. This strategy has been first observed in hot deserts [61] and Antarctic dry valleys [62]. Since photoinhibition by ultraviolet and visible light affects cyanobacterial photosynthetic activity at high daylight intensities [63], endolithic lifestyles increase the fitness of these terrestrial cyanobacteria. Generally, patterns of colonization observed by eukaryotic algae, but also fungi, imply that endolithic lifestyles are widespread, if not inevitable, when the colonized surface is exposed to high light intensities [64]. Though the environments of the Voltri sampling sites are aquatic (with dry seasons in summer), the water layers up to decimeter range do not reduce photoinhibition by visible light, because absorption of visible light is negligible. Though calcite is a translucent mineral, a layer of small calcite particles will reduce the overall light intensity by scattering. In addition, calcite absorbs ultraviolet light with a maximum at $240 \mathrm{~nm}$ wavelength [65].

Cyanobacterial filaments were covered with smaller cells of rod-like bacterial morphotypes, which is indicative for a bacterial community that benefits from the cyanobacterial primary producers (Figure $4 \mathrm{~b}$, inset). It is not known which part of the microbial community interacts with the cyanobacterial filaments, but bacterial epibionts have been repeatedly observed and characterized in freshwater and marine filamentous cyanobacteria [66-68]. The organisms may benefit from the cyanobacterial metabolic products such as extracellular glutamic acid; nutrient flow from cyanobacteria to heterotrophic bacteria in freshwater environment has been shown for Oscillatoria redekei (Limnothrix redekei) and 
isolates of heterotrophic bacteria [69]. It should not be neglected that cyanobacterial sheath exopolysaccharides, composed of well-biodegradable monosaccharides (cf. [70]), as well as decaying cells, may putatively feed the heterotrophic bacteria.

Among proteobacterial groups, a Hydrogenophaga-related OTU was most abundant in the alkaline springs. A subset of Hydrogenophaga-related strains comprises typical representatives of the highly alkaline and calcium-rich serpentinizing springs [45,46,71], including the Voltri spring sites [23]. These are also abundant in other alkaline water bodies [72]. Hydrogenophaga isolates are facultatively autotrophic bacteria, utilizing a variety of carbohydrates $[73,74]$, but also hydrogen and carbon monoxide; carbon dioxide fixation is conducted via the Calvin cycle [71]. In addition, mixotrophic growth on organic and inorganic substrates at the same time is possible, which may reflect the adaptation to the spring habitat where the availability of hydrogen gas may be rather low, in particular, in some distance to the spring site (cf. [15]), but input of organics from primary producers (as shown here) may provide substrates for a heterotrophic lifestyle.

A proteobacterial OTU related to Silanimonas is widespread in all sampled spring sites, and absent in creek water. Silanimonas strains are aerobic heterotrophic and alkaliphilic organisms $[25,75]$. Other Proteobacteria abundant in alkaline spring samples are Xanthomonadaceae and Hyphomonadaceae-related OTUs that cannot be further taxonomically resolved, but are representatives of oligotrophic freshwater bacteria, being widespread and not necessarily alkaliphilic. Two Tabrizicola-related OTUs are, though of higher abundance in many (but not all) of the spring sites, also present in freshwater. The type strain (Tabrizicola aquatica [76]) grows heterotrophically on various carbohydrates, and chemolithoautotrophically on reduced sulfur compounds.

One abundant retrieved Acetobacteriaceae OTU may be unexpected, because it belongs to a group with many acidophilic members, adapted to rather nutrient-rich habitats [77]. Genera related to these OTUs, however, are isolated from aquatic environments. The Acetobacteriaceae member Sediminicoccus rosea was isolated from a lake sediment [78] and Rhodovarius-strains are freshwater isolates as well [79]. One of the retrieved OTUs is also related to one detected in an Antarctic freshwater environment in a cyanobacterial mat covering a moss pillar [80]. None of these isolates or OTUs, however, were adapted to high-alkaline $\mathrm{pH}$.

Some taxa within the Bacteroidetes take benefit from the alkaline spring site habitat. Many OTUs related to this group are also abundant in freshwater samples, but in low counts. Bacteroidetes listed in Figure 5 are just associated with the alkaline springs. One important reason may be that members of the group take benefit from the presence of cyanobacteria as their primary resource of organic nutrients (cf. [81]).

Interestingly, the two dominant Luteolibacter OTUs are present either in the control sample or in alkaline spring sites. The related OTUs SINN488 and FGL7S_B75 were, according to NCBI database entries, retrieved from lake habitats [82,83]. Another verrucomicrobial OTU (Lacunisphaera-related [84]), occurs in the same samples from alkaline sites as Luteolibacter.

Taking the data together, the cyanobacterial mats of the serpentinizing springs are important primary producers, and are colonized by microorganisms known from other highly-alkaline water bodies; some few abundant representatives of them are also typical for other terrestrial serpentinizing springs. Many proteobacterial and Bacteroidetes-related OTUs may benefit from the organic input by the cyanobacterial mat.

An interaction between microbial cells and the carbonate precipitates of the spring sites is obvious and inevitable. Light and scanning electron microscopic analysis revealed the presence of microbial cells (putatively cyanobacterial sheaths) embedded in calcite fabric. Surfaces of these carbonates show a typical honeycomb structure, which often occurs at spring outflows (Figure 1a,b). The otherwise-white calcite shows a distinct brown stain due to impregnation with iron hydroxides. The light-yellow calcites from some Torrente Lerone springs show a periodic zonation of 10-20 $\mu \mathrm{m}$ in thickness and are reminiscent of microstromatolites (cf. [5]). Putatively, the zonation is caused by different contents of 
dispersed intracrystalline organic material, representing a mineralized polysacchariderich exopolymeric matrix of microbial mat remains. This periodicity may reflect seasonal changes in temperature and, hence, variation in evaporation rate of the outflowing spring water. In many other cases, no zonation is visible (cf. Figure 3a), but entrapped organics and prokaryotic cell shapes reveal that a bacterial biofilm must have been present and was rapidly encased by precipitation of calcites.

Isotopic values obtained from representative sampling sites turned out to be considerably variable. Torrente Lerone carbonates exhibit $\delta^{13} \mathrm{C}_{\mathrm{CaCO} 3}$ values between $-24 \%$ and $-11 \% ; \delta^{18} \mathrm{O}$ range from $-19 \%$ to $-9 \%$. In Torrente Branega, the measured $\delta^{13} \mathrm{C}$ values are close to $0 \%$, up to $+0.6 \%$. $\delta^{18} \mathrm{O}$ values range between $-20 \%$ and $-26 \%$. Generally, carbon isotope fractionation depends on two relevant processes, i.e., the equilibrium exchange reaction between atmospheric $\mathrm{CO}_{2}$, dissolved bicarbonate and precipitated carbonate $\left(\delta^{13} \mathrm{C}\right.$ in solid carbonate is enriched), and biological processes like methanogenesis, anaerobic oxidation of methane, or photosynthesis. The alkaline fluids seeping out of the serpentinite mountain massif are enriched in light carbon, possibly caused by anaerobic methane oxidation [15]. The surplus of isotopically-light dissolved carbonate ions (putatively generated by anaerobic methane oxidation in deep aquifers) precipitate fast to carbonates, close to the outflow of the spring. In increasing distance to the outflow, atmospheric carbon dioxide with a $\delta^{13} \mathrm{C}$ of c. $-8.5 \%$ [85] is equilibrating with remaining dissolved carbonate ions, and less depleted carbonates precipitate. This may explain the large range of $\delta^{13} \mathrm{C}$ values in the Torrente Lerone carbonates [19]. An influence of photosynthetic processes of cyanobacteria, which also retract ${ }^{12} \mathrm{C}$ from the carbon pool, cannot be excluded. Another travertine-type carbonate buildup taken from the Torrente Branega site differs from the Lerone locality. The measured $\delta^{13} \mathrm{C}$ values of carbonates are close to $0 \%$; few exhibit $+1.5 \%$ slightly heavier values, eventually caused by photosynthetic processes, as mentioned above. Interestingly, the $\delta^{13} \mathrm{C}$ values are in the same range as those of dissolved inorganic carbon (DIC) of seawater. It may be speculated that either the spring fluids reflect an original seawater signal or that the originally isotopically light carbon in meteoric water (c. $\delta^{13} \mathrm{C}_{\mathrm{CO} 2 \mathrm{~atm}}-8.5 \%$, see above) was depleted in ${ }^{12} \mathrm{C}$ during, e.g., methanogenesis within the aquifers of the Voltri Massif. Consequently, the remaining fluid became a less depleted "seawater" signal. Methanogenic and methanotrophic archaea, both involved in carbon isotope fractionation, were already detected in spring water from the Voltri Massif. Several studies $[15,17,19]$ reported similar $\delta^{13} \mathrm{C}$ and $\delta^{18} \mathrm{O}$ values in carbonates as seen in the Torrente Lerone carbonate buildups, whereas our data from Torrente Branega considerably differ from these findings. Various types of water feeding the springs may explain this. A substantial influence of photosynthetic processes in carbonate fractionation could not be observed.

\section{Conclusions}

A specific deep biosphere methane- and hydrogen-metabolizing community may inhabit deep aquifers in serpentinizing spring sites. Close to outflows and in alkaline pools at spring sites, the microbial community has changed: few cyanobacterial OTUs (a Leptolyngbyales-related strain and an Oscillatoriales-related strain with up to 30\% and up to $14 \%$ of all retrieved OTUs in single samples, respectively) are by far the most abundant bacteria forming mats associated with precipitated carbonates. They are nearly absent in reference samples from creek water. A fast (chemical, non-biological) precipitation of carbonates is influenced by cyanobacterial exopolymeric substances, which becomes obvious when consolidated microstromatolite-like carbonate buildups are formed. There is, however, no considerable difference in microbial communities for more or less consolidated carbonates. Though the spring site water body is oligotrophic, and cyanobacterial layers are rather inconspicuous, they may develop undisturbed by grazers, due to the ultra-high $\mathrm{pH}$, and provide a small, but continuous, nutrient resource for a bacterial community, associated with the cyanobacterial filaments. 
Supplementary Materials: The following are available online at https:/ / www.mdpi.com/2076-260 7/9/1/62/s1, Figure S1: Stable $\delta^{13} \mathrm{C}_{\mathrm{CaCO} 3}$ and $\delta^{18} \mathrm{O}_{\mathrm{CaCO} 3}$ isotopic records of samples from carbonate buildups (Torrente Lerone/Torrente Branega sampling sites as indicated) and samples from cemented carbonate fractures within ophicalcites NE of Bonassola/La Spezia. Figure S2: Rarefaction curve depicting all samples as indicated. Table S1: Extended table of all hydrochemical data taken from alkaline springs and from creek water as indicated.

Author Contributions: Conceptualization: A.K., J.R., T.W., and M.H.; methodology: A.K., K.S., A.R., and T.W.; software: K.S.; formal analysis: A.K. and K.S.; writing-original draft preparation: A.K. and M.H.; writing-review and editing: A.K., K.S., A.R., T.W., J.R., and M.H. All authors have read and agreed to the published version of the manuscript.

Funding: This research was partially funded by the Alexander von Humboldt Foundation and the Göttingen Academy of Science and Humanities.

Acknowledgments: The authors greatly acknowledge Dorothea Hause-Reitner, Axel Hackmann, and Wolfang Dröse (Geoscience Centre Göttingen) for technical support. Stable isotope analyses were carried in the department of isotope geology (Andreas Pack, Geoscience Centre Göttingen). This is publication number 8 of the Early Life Research Group of Göttingen Academy of Sciences and Humanities.

Conflicts of Interest: The authors declare no conflict of interest.

\section{References}

1. Berner, R.A. The long-term carbon cycle, fossil fuels and atmospheric composition. Nat. Cell Biol. 2003, 426, 323-326. [CrossRef]

2. Fine, R.A.; Willey, D.A.; Millero, F.J. Global variability and changes in ocean total alkalinity from Aquarius satellite data. Geophys. Res. Lett. 2017, 44, 261-267. [CrossRef]

3. Borowitzka, M.A.; Larkum, A.W.D. Calcification in algae: Mechanism and the role of metabolism. Crit. Rev. Plant Sci. 1987, 6, 1-45. [CrossRef]

4. Arp, G.; Reimer, A.; Reitner, J. Photosynthesis-induced biofilm calcification and calcium concentrations in Phanerozoic oceans. Science 2001, 292, 1701-1704. [CrossRef]

5. Arp, G.; Reimer, A.; Reitner, J. Microbialite formation in seawater of increased alkalinity, Satonda Crater Lake, Indonesia. J. Sediment. Res. 2003, 73, 105-127. [CrossRef]

6. Braissant, O.; Decho, A.W.; Dupraz, C.; Glunk, C.; Przekop, K.M.; Visscher, P.T. Exo-polymeric substances of sulfate-reducing bacteria: Interactions with calcium at alkaline $\mathrm{pH}$ and implication for formation of carbonate minerals. Geobiology 2007, 5, 401-411. [CrossRef]

7. Mann, S. Molecular recognition in biomineralization. Nature 1988, 332, 119-124. [CrossRef]

8. Riding, R. Microbial carbonates: The geological record of calcified bacterial-algal mats and biofilms. Sedimentology 2000, 47, 179-214. [CrossRef]

9. Kamennaya, N.A.; Ajo-Franklin, C.M.; Northen, T.; Jansson, C. Cyanobacteria as Biocatalysts for Carbonate Mineralization. Rev. Miner. 2012, 2, 338-364. [CrossRef]

10. Arp, G.; Reimer, A.; Reitner, J. Microbial fabric formation in spring mounds ('Microbialites') of alkaline salt lakes in the Badain Jaran Sand sea, PR China. Palaios 1998, 13, 581. [CrossRef]

11. Arp, G.; Reimer, A.; Reitner, J. Biofilm exopolymers control microbialite formation at thermal springs discharging into the alkaline Pyramid Lake, Nevada, USA. Sediment. Geol. 1999, 126, 159-176. [CrossRef]

12. Arp, G.; Helms, G.; Karlinska, K.; Schumann, G.; Reimer, A.; Reitner, J.; Trichet, J. Photosynthesis versus exopolymer degradation in the formation of microbialites on the atoll of Kiritimati, Republic of Kiribati, Central Pacific. Geomicrobiol. J. 2012, 29, 29-65. [CrossRef]

13. Bruni, J.; Canepa, M.; Chiodini, G.; Cioni, R.; Cipolli, F.; Longinelli, A.; Marini, L.; Ottonello, G.; Zuccolini, M. Irreversible water-rock mass transfer accompanying the generation of the neutral, $\mathrm{Mg}-\mathrm{HCO} 3$ and high-pH, $\mathrm{Ca}-\mathrm{OH}$ spring waters of the Genova province, Italy. Appl. Geochem. 2002, 17, 455-474. [CrossRef]

14. Cipolli, F.; Gambardella, B.; Marini, L.; Ottonello, G.; Zuccolini, M. Geochemistry of high-pH waters from serpentinites of the Gruppo di Voltri (Genova, Italy) and reaction path modeling of $\mathrm{CO} 2$ sequestration in serpentinite aquifers. Appl. Geochem. 2004, 19, 787-802. [CrossRef]

15. Brazelton, W.J.; Thornton, C.N.; Hyer, A.; Twing, K.I.; Longino, A.A.; Lang, S.Q.; Lilley, M.D.; Früh-Green, G.L.; Schrenk, M.O. Metagenomic identification of active methanogens and methanotrophs in serpentinite springs of the Voltri Massif, Italy. Peer J. 2017, 5, e2945. [CrossRef] [PubMed]

16. Hammer, U.T. Monographiae Biologcae, Saline Lake Ecosystems of the World, 1st ed.; Springer: Berlin, Germany, $1986 ;$ p. 59.

17. Quéméneur, M.; Palvadeau, A.; Postec, A.; Monnin, C.; Chavagnac, V.; Ollivier, B.; Erauso, G. Endolithic microbial communities in carbonate precipitates from serpentinite-hosted hyperalkaline springs of the Voltri Massif (Ligurian Alps, Northern Italy). Environ. Sci. Pollut. Res. 2015, 22, 13613-13624. [CrossRef] 
18. Boulart, C.; Chavagnac, V.; Monnin, C.; Delacour, A.; Ceuleneer, G.; Hoareau, G. Differences in gas venting from ultramafic-hosted warm springs: The example of Oman and Voltri ophiolites. Ofioliti 2013, 38, 142-156.

19. Schwarzenbach, E.M.; Lang, S.Q.; Früh-Green, G.L.; Lilley, M.; Bernasconi, S.M.; Méhay, S. Sources and cycling of carbon in continental, serpentinite-hosted alkaline springs in the Voltri Massif, Italy. Lithos 2013, 177, 226-244. [CrossRef]

20. Vignaroli, G.; Rossetti, F.; Rubatto, D.; Theye, T.; Lisker, F.; Phillips, D. Pressure-temperature-deformation-time (P-Td-t) exhumation history of the Voltri Massif HP complex, Ligurian Alps, Italy. Tectonics 2010, 29, 6009. [CrossRef]

21. Preiner, M.; Igarashi, K.; Muchowska, K.B.; Yu, M.; Varma, S.J.; Kleinermanns, K.; Nobu, M.K.; Kamagata, Y.; Tüysüz, H.; Moran, J.; et al. A hydrogen-dependent geochemical analogue of primordial carbon and energy metabolism. Nat. Ecol. Evol. 2020, 4, 534-542. [CrossRef]

22. Palandri, J.A.; Reed, M.H. Geochemical models of metasomatism in ultramafic systems: Serpentinization, rodingitization, and sea floor carbonate chimney precipitation. Geochim. Cosmochim. Acta 2004, 68, 1115-1133. [CrossRef]

23. Giampouras, M.; Garrido, C.J.; Zwicker, J.; Vadillo, I.; Smrzka, D.; Bach, W.; Peckmann, J.; Jiménez, P.; Benavente, J.; García-Ruiz, J.M. Geochemistry and mineralogy of serpentinization-driven hyperalkaline springs in the Ronda peridotites. Lithos 2019, 350, 105215. [CrossRef]

24. Tiago, I.; Chung, A.P.; Veríssimo, A. Bacterial diversity in a nonsaline alkaline environment: Heterotrophic aerobic populations. Appl Environ. Microbiol. 2004, 70, 7378-7387. [CrossRef]

25. Tiago, I.; Verissimo, A. Microbial and functional diversity of a subterrestrial high $\mathrm{pH}$ groundwater associated to serpentinization. Environ. Microbiol. 2012, 15, 1687-1706. [CrossRef]

26. Soetaert, K.; Hofmann, A.F.; Middelburg, J.J.; Meysman, F.J.R.; Greenwood, J. Reprint of “The effect of biogeochemical processes on $\mathrm{pH}^{\prime \prime}$. Mar. Chem. 2007, 106, 380-401. [CrossRef]

27. Grasshoff, K.; Kremling, K.; Ehrhardt, M. Methods of Seawater Analysis; John Wiley \& Sons: Hoboken, NJ, USA, 2009.

28. Parkhurst, D.L.; Appelo, C.A.J. Description of Input and Examples for PHREEQC Version 3dA computer program for speciation, batch reaction, one dimensional transport, and Inverse geochemical calculations. US Geol. Surv. Tech. Methods 2013, 6, 497.

29. Reitner, J. Modern cryptic microbialite/metazoan facies from Lizard Island (Great Barrier Reef, Australia)-formation and concepts. Facies 1993, 29, 3-39. [CrossRef]

30. Kokoschka, S.; Dreier, A.; Romoth, K.; Taviani, M.; Schafer, N.; Reitner, J.; Hoppert, M. Isolation of anaerobic bacteria from terrestrial mud volcanoes (Salse di Nirano, Northern Apennines, Italy). Geomicrobiol. J. 2015, 32, 355-364. [CrossRef]

31. Klindworth, A.; Pruesse, E.; Schweer, T.; Peplies, J.; Quast, C.; Horn, M.; Glöckner, F.O. Evaluation of general 16S ribosomal RNA gene PCR primers for classical and next-generation sequencing-based diversity studies. Nucleic Acids Res. 2012, 41, e1. [CrossRef]

32. Sambrook, J.; MacCallum, P.D.; Russel, D. Molecular Cloning. A Laboratory Manual, 3rd ed.; CSH Laboratory Press: Cold Spring Harbour, NY, USA, 2000.

33. Andrews, S.; Lindenbaum, P.; Howard, B.; Ewels, P. FastQC [Computer Software]. 2015. Available online: https://www. bioinformatics.babraham.ac.uk/projects/fastqc/ (accessed on 22 December 2020).

34. Masella, A.P.; Bartram, A.K.; Truszkowski, J.M.; Brown, D.G.; Neufeld, J.D. PANDAseq. Paired-end assembler for illumina sequences. BMC Bioinform. 2012, 13, 31. [CrossRef]

35. Zhang, J.; Kobert, K.; Flouri, T.; Stamatakis, A. PEAR. A fast and accurate Illumina Paired-End read merger. Bioinformatics 2014, 30, 614-620. [CrossRef] [PubMed]

36. Martin, M. Cutadapt removes adapter sequences from high-throughput sequencing reads. EMBnet. J. 2011, 17, 10-12. [CrossRef]

37. Caporaso, J.G.; Kuczynski, J.; Stombaugh, J.; Bittinger, K.; Bushman, F.D.; Costello, E.K.; Fierer, N.; Peña, A.G.; Goodrich, J.K.; Gordon, J.I.; et al. QIIME allows analysis of high-throughput community sequencing data. Nat. Methods 2010, 7, 335-336. [CrossRef] [PubMed]

38. Yilmaz, P.; Parfrey, L.W.; Yarza, P.; Gerken, J.; Pruesse, E.; Quast, C.; Schweer, T.; Peplies, J.; Ludwig, W.; Glöckner, F.O. The SILVA and "All-species Living Tree Project (LTP)" taxonomic frameworks. Nucl. Acids Res. 2014, 42, D643-D648. [CrossRef]

39. Lozupone, C.; Knight, R. UniFrac: A new phylogenetic method for comparing microbial communities. Appl. Environ. Microbiol. 2005, 71, 8228-8235. [CrossRef]

40. Vázquez-Baeza, Y.; Pirrung, M.; Gonzalez, A.; Knight, R. EMPeror: A tool for visualizing high-throughput microbial community data. GigaScience 2013, 2, 16. [CrossRef]

41. Hulsen, T.; de Vlieg, J.; Alkema, W. BioVenn-A web application for the comparison and visualization of biological lists using area-proportional Venn diagrams. BMC Genom. 2008, 9, 488. [CrossRef]

42. Shopov, Y.Y. Activators of luminescence in speleothems as source of major mistakes in interpretation of luminescent paleoclimatic records. Int. J. Speleol 2004, 33, 25-33. [CrossRef]

43. Schwarzenbach, E.; Früh-Green, G.; Bernasconi, S.; Alt, J.C.; Plas, A. Serpentinization and carbon sequestration: A study of two ancient peridotite-hosted hydrothermal systems. Chem. Geol. 2013, 351, 115-133. [CrossRef]

44. Kelley, D.S.; Karson, J.A.; Früh-Green, G.L.; Yoerger, D.R.; Shank, T.M.; Butterfield, D.A.; Hayes, J.M.; Schrenk, M.O.; Olson, E.J.; Proskurowski, G.; et al. A serpentinite-hosted ecosystem: The Lost City Hydrothermal Field. Science 2005, 307, 1428-1434. [CrossRef]

45. Quéméneur, M.; Bes, M.; Postec, A.; Mei, N.; Hamelin, J.; Monnin, C.; Chavagnac, V.; Payri, C.; Pelletier, B.; Guentas-Dombrowsky, L.; et al. Spatial distribution of microbial communities in the shallow submarine alkaline hydrothermal field of the Prony Bay, New Caledonia. Environ. Microbiol. Rep. 2014, 6, 665-674. [CrossRef] [PubMed] 
46. Brazelton, W.J.; Morrill, P.L.; Szponar, N.; Schrenk, M.O. Bacterial communities associated with subsurface geochemical processes in continental serpentinite springs. Appl. Environ. Microbiol. 2013, 79, 3906-3916. [CrossRef] [PubMed]

47. Suzuki, S.; Ishii, S.; Wu, A.; Cheung, A.; Tenney, A.; Wanger, G.; Kuenen, J.G.; Nealson, K.H. Microbial diversity in the Cedars, an ultrabasic, ultrareducing, and low salinity serpentinizing ecosystem. Proc. Natl. Acad. Sci. USA 2013, 110, 15336-15341. [CrossRef] [PubMed]

48. Woycheese, K.M.; Meyer-Dombard, D.R.; Cardace, D.; Argayosa, A.M.; Arcilla, C.A. Out of the dark: Transitional subsurface-tosurface microbial diversity in a terrestrial serpentinizing seep (Manleluag, Pangasinan, the Philippines). Front. Microbiol. 2015, 6, 44. [CrossRef] [PubMed]

49. Merino, N.; Kawai, M.; Boyd, E.S.; Colman, D.R.; McGlynn, S.E.; Nealson, K.H.; Kurokawa, K.; \& Hongoh, Y. Single-cell genomics of novel Actinobacteria with the Wood-Ljungdahl pathway discovered in a serpentinizing system. Front. Microbiol. 2020, 11, 1031. [CrossRef]

50. Cardace, D.; Hoehler, T.; McCollom, T.; Schrenk, M.; Carnevale, D.; Kubo, M.; Twing, K. Establishment of the Coast Range ophiolite microbial observatory (CROMO): Drilling objectives and preliminary outcomes. Sci. Drill. 2013, 16, 45-55. [CrossRef]

51. Crespo-Medina, M.; Twing, K.I.; Kubo, M.D.Y.; Hoehler, T.M.; Cardace, D.; McCollom, T.; Schrenk, M.O. Insights into environmental controls on microbial communities in a continental serpentinite aquifer using a microcosm-based approach. Front. Microbiol. 2014, 5, 604. [CrossRef]

52. Andreote, A.P.; Vaz, M.G.; Genuário, D.B.; Barbiero, L.; Rezende-Filho, A.T.; Fiore, M.F. Nonheterocytous cyanobacteria from Brazilian saline-alkaline lakes. J. Phycol. 2014, 50, 675-684. [CrossRef]

53. Hallenbeck, P.C.; Grogger, M.; Mraz, M.; Veverka, D. Draft Genome Sequence of a Thermophilic Cyanobacterium from the Family Oscillatoriales (Strain MTP1) from the Chalk River, Colorado. Genome Announc. 2016, 4, 01571-15. [CrossRef]

54. Shiraishi, F.; Hanzawa, Y.; Okumura, T.; Tomioka, N.; Kodama, Y.; Suga, H.; Takahashi, Y.; Kano, A. Cyanobacterial exopolymer properties differentiate microbial carbonate fabrics. Sci. Rep. 2017, 7, 1-8. [CrossRef]

55. Allen, M.M. Simple conditions for growth of blue-green algae on plates. J. Phycol. 1968, 4, 1-4. [CrossRef] [PubMed]

56. Blank, J.G.; Green, S.J.; Blake, D.; Valley, J.W.; Kita, N.T.; Treiman, A.; Dobson, P.F. An alkaline spring system within the Del Puerto Ophiolite (California, USA): A Mars analog site. Planet. Space Sci. 2009, 57, 533-540. [CrossRef]

57. Meyer-Dombard, D.A.R.; Woycheese, K.M.; Yargıçoğlu, E.N.; Cardace, D.; Shock, E.L.; Güleçal-Pektas, Y.; Temel, M. High pH microbial ecosystems in a newly discovered, ephemeral, serpentinizing fluid seep at Yanartaş (Chimera), Turkey. Front. Microbiol. 2015, 5, 723. [CrossRef] [PubMed]

58. Neubeck, A.; Sun, L.; Müller, B.; Ivarsson, M.; Hosgörmez, H.; Özcan, D.; Broman, C.; Schnürer, A. Microbial community structure of a serpentine-hosted abiotic gas seepage at the Chimaera ophiolite, Turkey. App Environ. Microbiol. 2017, 83, 03430-16. [CrossRef]

59. Pentecost, A.; Franke, U. Photosynthesis and calcification of the stromatolitic freshwater cyanobacterium Rivularia. Eur. J. Phycol. 2010, 45, 345-353. [CrossRef]

60. Couradeau, E.; Roush, D.; Guida, B.S.; Garcia-Pichel, F. Diversity and mineral substrate preference in endolithic microbial communities from marine intertidal outcrops (Isla de Mona, Puerto Rico). Biogeosciences 2017, 14, 311-324. [CrossRef]

61. Friedmann, I.; Lipkin, Y.; Ocampus-Paus, R. Desert algae of the Negev (Israel). Phycologia 1967, 6, 185-200. [CrossRef]

62. Friedmann, E.I.; Ocampo, R. Endolithic blue-green algae in the dry valleys: Primary producers in the Antarctic desert ecosystem. Science 1976, 193, 1247-1249. [CrossRef]

63. Harel, Y.; Ohad, I.; Kaplan, A. Activation of photosynthesis and resistance to photoinhibition in cyanobacteria within biological desert crust. Plant Physiol. 2004, 136, 3070-3079. [CrossRef]

64. Kemmling, A.; Kämper, M.; Flies, C.; Schieweck, O.; Hoppert, M. Biofilms and extracellular matrices on geomaterials. Environ. Geol. 2004, 46, 429-435. [CrossRef]

65. Omari, M.M.H.; Rahid, I.S.; Qinna, N.A.; Jaber, A.M.; Badwan, A.A. Calcium carbonate. In Profiles of Drug Substances, Excipients, and Related Methodology; Britain, H.G., Ed.; Elsevier Inc.: Amsterdam, The Netherlands, 2016; Volume 41, pp. 31-132. [CrossRef]

66. Müller, U.; Sengbusch, P.V. Interactions of species in an Anabaena flos-aquae association from the Plußsee (East-Holstein, Federal Republic of Germany). Oecologia 1983, 58, 215-219. [CrossRef] [PubMed]

67. Kämper, M.; Vetterkind, S.; Berker, R.; Hoppert, M. Methods for in situ detection and characterization of extracellular polymers in biofilms by electron microscopy. J. Microbiol. Methods 2004, 57, 55-64. [CrossRef] [PubMed]

68. Hmelo, L.R.; Van Mooy, B.A.S.; Mincer, T.J. Characterization of bacterial epibionts on the cyanobacterium Trichodesmium. Aquat. Microb. Ecol. 2012, 67, 1-14. [CrossRef]

69. Herbst, V.; Overbeck, J. Metabolic coupling between the alga Oscillatoria redekei and accompanying bacteria. Naturwissenschaften 1978, 65, 598-599. [CrossRef]

70. De Philippis, R.; Vincenzini, M. Exocellular polysaccharides from cyanobacteria and their possible applications. FEMS Microbiol. Rev. 1998, 22, 151-175. [CrossRef]

71. Suzuki, S.; Kuenen, J.G.; Schipper, K.; van der Velde, S.; Ishii, S.; Wu, A.; Sorokin, D.Y.; Tenney, A.; Meng, X.; Morrill, P.L.; et al. Physiological and genomic features of highly alkaliphilic hydrogen-utilizing Betaproteobacteria from a continental serpentinizing site. Nat. Commun. 2014, 5, 3900. [CrossRef]

72. Roadcap, G.S.; Sanford, R.A.; Jin, Q.; Pardinas, J.R.; Bethke, C.M. Extremely alkaline (pH 12) ground water hosts diverse microbial community. Groundwana Res. 2006, 44, 511-517. [CrossRef] 
73. Auling, G.; Reh, M.; Lee, C.M.; Schlegel, H.G. Pseudomonas pseudoflava, a new species of hydrogen oxidizing bacteria: Its differentiation from Pseudomonas flaya and other yellow-pigmented, Gram-negative, hydrogen-oxidizing species. Int. J. Syst. Bacteriol. 1978, 28, 82-95. [CrossRef]

74. Willems, A.; Busse, J.; Goor, M.; Pot, B.; Falsen, E.; Jantzen, E.; Hoste, B.; Gillis, M.; Kersters, K.; Auling, G.; et al. Hydrogenophaga, a new genus of hydrogen-oxidizing bacteria that includes Hydrogenophaga flava comb. nov. (formerly Pseudomonas flava), Hydrogenophaga palleronii (formerly Pseudomonas palleronii), Hydrogenophaga pseudoflava (formerly Pseudomonas pseudoflava and 'Pseudomonas carboxydoflava') and Hydrogenophaga taeniospiralis (formerly Pseudomonas taeniospiralis). Int. J. Syst. Bacteriol. 1989, 39, 319-333. [CrossRef]

75. Lee, E.M.; Jeon, C.O.; Choi, I.; Chang, K.S.; Kim, C.J. Silanimonas lenta gen. nov., sp. nov., a slightly thermophilic and alkaliphilic gammaproteobacterium isolated from a hot spring. Int. J. Syst. Evol. Microbiol. 2005, 55, 385-389. [CrossRef]

76. Tarhriz, V.; Theil, V.; Nematzadeh, G.; Hejazi, M.A.; Imhoff, J.F.; Hejazi, M.S. Tabrizicola aquatica gen. nov. sp. nov., a novel alphaproteobacterium isolated from Qurugol Lake nearby Tabriz city, Iran. Antonie Van Leeuwenhoek 2013, 104, $1205-1215$. [CrossRef] [PubMed]

77. Komagata, K.; Iino, T.; Yamada, Y. The family Acetobacteraceae. In The Prokaryotes-Alphaproteobacteria and Betaproteobacteria; Rosenberg, E., Long, E.F., Lory, S., Stackebrandt, E., Thompson, F., Eds.; Springer: Berlin, Germany, 2014; pp. 3-78.

78. Qu, J.-H.; He, X.-B.; Li, H.-F.; Luo, Y.; Yin, Y.-L.; Zhai, H.-C.; Cai, J.-P. Sediminicoccus rosea gen. nov. sp. nov., isolated from the sediment of a eutrophic lake. J. Gen. Appl. Microbiol. 2013, 59, 463-468. [CrossRef] [PubMed]

79. Chen, W.M.; Xie, Y.R.; Sheu, D.S.; Tsai, J.M.; Sheu, S.Y. Rhodovarius crocodyli sp. nov., isolated from a crocodile pond. Int. J. Syst. Evol. Microbiol. 2020, 70, 5141-5148. [CrossRef] [PubMed]

80. Nakai, R.; Abe, T.; Baba, T.; Imura, S.; Kagoshima, H.; Kanda, H.; Kanekiyo, A.; Kohara, Y.; Koi, A.; Nakamura, K.; et al. Microflorae of aquatic moss pillars in a freshwater lake, East Antarctica, based on fatty acid and 16S rRNA gene analyses. Polar Biol. 2011, 35, 425-433. [CrossRef]

81. Eiler, A.; Bertilsson, S. Flavobacteria blooms in four eutrophic lakes: Linking population dynamics of freshwater bacterioplankton to resource availability. Appl. Environ. Microbiol. 2007, 73, 3511-3518. [CrossRef]

82. Meyer, K.M.; Macalady, J.L.; Fulton, J.M.; Kump, L.R.; Schaperdoth, I.; Freeman, K.H. Carotenoid biomarkers as an imperfect reflection of the anoxygenic phototrophic community in meromictic Fayetteville Green Lake. Geobiology 2011, 9, 321-329. [CrossRef]

83. Zhang, R.; Wu, Q.; Piceno, Y.M.; Desantis, T.Z.; Saunders, F.M.; Andersen, G.L.; Liu, W.T. Diversity of bacterioplankton in contrasting Tibetan lakes revealed by high-density microarray and clone library analysis. FEMS Microbiol. Ecol. 2013, 86, 277-287. [CrossRef]

84. Rast, P.; Glöckner, I.; Boedeker, C.; Jeske, O.; Wiegand, S.; Reinhardt, R.; Schumann, P.; Rohde, M.; Spring, S.; Glöckner, F.O.; et al. Three novel species with peptidoglycan cell walls form the new genus Lacunisphaera gen.nov. in the family Opitutaceae of the Verrucomicrobial subdivision 4. Front. Microbiol. 2017, 8, 202. [CrossRef]

85. Longinelli, A.; Selmo, E. $\mathrm{CO}_{2}$ concentrations and $\delta^{13} \mathrm{C}_{(\mathrm{CO} 2)}$ values in monthly sets of air samples from downtown Parma and the Parma and Taro river valleys, Emilia-Romagna, Italy. Isot. Environ. Health Stud. 2006, 42, 215-230. [CrossRef] 


\section{General Discussion}

\subsection{Carbonate precipitates encasing and conserving biomass}

Carbonates, calcium carbonate in particular, are the most important minerals for encasement and preservation of biological structures in sediments (Durand et al., 2010). In fact, carbonates take place in the earliest steps of fossilization and may end up by the nearly complete exchange of organic matter against a mineral phase, though residual organics is still present even after millions of years (e.g. Welte, 1969). There are many lines of evidence that the initial step in mineralization is not just a simple formation of a carbonate cast around an organic structure, but the formation of an organomineral, i.e. a mineral formed in close interaction with biomolecules, deriving either from the fossilizing organics, or from the microbial biomass that derived from the decay process (e.g., Reitner et al., 2004; Arp et al., 2010, 2012; Della Porta et al., 2021). In the first part of the thesis, the microbial formation of siderite was demonstrated, which is a carbonate mineral taking part in fossiliferous concretion formation.

\subsubsection{Occurrence of carbonate concretions in sediments}

In this thesis, just a (hypothetical) initial step of siderite concretion formation was observed, i.e. the formation of small microscale precipitates on cell surfaces. Until a concretion at macroscale has been formed, a time span between 50 years up to more than 30 million years was given, though most estimates ranged between $10^{4}$ to $10^{5}$ years (Coleman, 1993; SellésMartínez, 1996). Numerous studies point to microbial activity as a key process in the initiation of concretion formation. This is justified to assume when partially degraded or fossilized biological material is present inside a concretion and could serve as a growth substrate in the initial stage of concretion formation (Plet et al., 2017). Microbial key players, though, have not 
yet been identified. In most of the studies, growth of carbonate concretions is lead back to supersaturation of calcium ions in pore waters which typically results from increased alkalinity generated by microbial organic matter decay (e.g. Sellés-Martínez, 1996; Loyd et al., 2012). The $\delta^{13} \mathrm{C}$ values of carbonates of the concretion matrix are often used to determine the source of the carbon in carbonate and hence the origin of carbon dioxide. Coleman (1993) listed some microbial key processes involved in concretion formation as identified by pore water chemistry and carbon isotope signatures. Two types of concretions, from recent salt marsh sediments (Norfolk, UK; as already discussed in Chapter 2) and concretions from a quarry in Yorkshire (Bullhouse quarry, Hepworth) are mainly composed of siderite. In the former (salt marsh sediment), microbial sulfate reduction and iron reduction were considered. For the latter process, also because of the absence of sulfate in the host sediment, microbial manganese reduction and iron reduction, but no sulfate reduction were proposed.

Without any leftovers, identification of substrates for the microbial processes are not possible. Whereas sometimes ancient organic remains may be identifiable as fossils, not all concretions develop around such a core and biomarkers are sometimes ambiguous. Methanotrophic sulfate reduction as a precipitation mechanism was considered for pyritiferous carbonate concretions from Port Mulgrave ("Jet Rock", Whitby/Yorkshire) though the carbon isotope compositions (Raiswell, 1987) were inconclusive. Carbon isotope depletion below a $\delta^{13} \mathrm{C}$ of about $\sim-25 \%$ are indicative for carbon dioxide derived from methane as a carbon source. Intermediate values (between -25 and 0\%), are indicative for mixtures of different carbon sources, still including methane. This intermediate range has been determined for many concretionary carbonates, including the above mentioned "Jet Rock" concretions. This, in fact, implies mixture with isotopically heavier carbonate, derived from organic matter decay by, e.g., sulfate reduction (Raiswell, 1987; Mozley and Burns, 1993). There are many examples for the involvement of methane in formation of calcium carbonate (and dolomite) concretions at methane seepage sites 
(e.g., Reitner et al., 2005), exhibiting much lower $\delta{ }^{13} \mathrm{C}$ values. They are related to anaerobic oxidation of methane in sediments. The role of all these process in formation of ancient carbonate concretions should be further resolved by addressing isotopic signatures beyond carbon and oxygen (Loyd and Berelson, 2016).

Apparently the formation of iron carbonate (siderite) requires well-balanced redox, $\mathrm{pH}$ and alkalinity values (cf. Lin et al., 2020 and references therein). The environment must be anoxic due to the rapid oxidation of iron with oxygen, but anoxic conditions may also promote sulfate reduction (if sulfate is available) and formation of iron sulfide instead of siderite. Another important prerequisite appears to be carbonate supersaturation in pore fluids by all (respiratory or fermentative) microbial processes, resulting in production of $\mathrm{CO}_{2}$ or dissolved $\mathrm{HCO}_{3}{ }^{-}$and $\mathrm{CO}_{3}{ }^{2-}$ (Pye et al., 1990; Coleman, 1993; Lin et al., 2020). Hence, formation of carbonate concretions depends on the preferential anaerobic respiratory processes. Anaerobic respiration with $\mathrm{MnO}_{2}$ as electron acceptor results in formation of $\mathrm{Mn}^{2+}$ ions (Curtis et al., 1986):

$2 \mathrm{MnO}_{2}+\mathrm{CH}_{2} \mathrm{O}+\mathrm{H}_{2} \mathrm{O} \rightarrow \mathrm{HCO}_{3}{ }^{-}+2 \mathrm{Mn}^{2+}+3 \mathrm{OH}^{-}$

when Mn (IV) in manganese oxides is present. The alternative process with iron oxide will be:

$2 \mathrm{Fe}_{2} \mathrm{O}_{3}+\mathrm{CH}_{2} \mathrm{O}+3 \mathrm{H}_{2} \mathrm{O} \rightarrow \mathrm{HCO}_{3}^{-}+4 \mathrm{Fe}^{2+}+7 \mathrm{OH}^{-}$

with $\mathrm{CH}_{2} \mathrm{O}$ as a simplified formula for organic compounds. These processes nearly co-occur in sediments, with manganese reduction layered above the zone of iron reduction (Nealson and Saffarini, 1994).

The reactions, increasing alkalinity, precipitate carbonate minerals:

$$
\begin{aligned}
& \mathrm{Mn}^{2+}+\mathrm{OH}^{-}+\mathrm{HCO}_{3}{ }^{-} \rightarrow \mathrm{MnCO}_{3}+\mathrm{H}_{2} \mathrm{O} \\
& \mathrm{Fe}^{2+}+\mathrm{OH}^{-}+\mathrm{HCO}_{3}{ }^{-} \rightarrow \mathrm{FeCO}_{3}+\mathrm{H}_{2} \mathrm{O}
\end{aligned}
$$


Respective concretionary manganese and iron carbonates may be retrieved from sedimentary layers (Nealson and Saffarini, 1994). At lower redox potential, below manganese- and iron reducing sedimentary layers, iron sulfides (see above) are formed, when sulfate is available. Though this layering may be an oversimplification for many systems (cf. Fussmann et al., 2020), this way of redox-stratification in sediments is common for marine (coastal) sediments. Interestingly, sediments and their redox stratification are important proxies for the history of oxygenation in ocean systems as well as oxygenation of the atmosphere (Gill et al., 2011; Sperling et al., 2015), whereby burrowing animals have, when available, strongly perturbed the redox layers (Tarhan et al., 2015). These redox stratified marine environments also affected fossil preservation. Buried carcasses are preserved al low microbial activity, but $\mathrm{O}_{2}$ and $\mathrm{SO}_{4}{ }^{2-}$ appeared to be drivers of microbial metabolism and hence decay. In aerobic layers and in sulfate reduction zones soft tissues are generally most aggressively degraded (Allison and Briggs, 1993; Canfield and Farquhar, 2009; Schiffbauer et al., 2014; Tarhan et al., 2015; Muscente and Xiao, 2015a;). Apparently, prevalence of microbial mats, which facilitate authigenic/diagenetic mineralization (Wilby et al., 1996) are also important for redox stratification and hence fossil formation. They seal fossils off from oxic or suboxic bottom waters (Gehling, 1999; Laflamme et al., 2011) and prevent loss of chemical compounds involved in fossil formation (Callow and Brasier, 2009; Muscente and Xiao., 2015a). This directly promotes preservation of carcasses and organic remains until they undergo authigenic/diagenetic mineralization finally preventing loss of their physical structure. These conditions occurred rather locally or regionally, eventually in coastal brackish or even in non-marine depositional settings, where since late Paleozoic soft tissue remains were preserved (Allison and Briggs, 1991, 1993). 


\subsection{Microbial processes involved in iron mineral formation}

In modern environments, bacterial populations will vary with depth of the sedimentary layer overlay by an oxygenated water body. The zone of aerobic respiration at the sediment-water interface followed by an anaerobic zone of nitrate-, manganese-, and iron-reducing microbial activity requires different groups of organisms. Lowermost layers of microbial activity are the bacterial sulfate reduction (BSR) zone with sulfate reducing bacteria and finally the methanogenesis zone with methanogenic archaea (Goldhaber and Kaplan, 1975; Froelich et al., 1979; Reeburgh, 1983; Nealson, 1997; Biddle et al., 2005).

In this research, operational taxonomic units (OTUs) assigned to typical anaerobic respiratory, mainly sulfate reducing, Deltaproteobacteria were higher abundant in the substrate Span 80 and lower in lime soap, which may be due to its chemical composition and the hydrophobicity of the latter substrate. The weighted and unweighted PCoA plot showed similarities in almost all samples drawn after 3 days. Major dissimilarities were observed after 15 days between all used substrates being easily degradable (Span 20, 80, linseed oil and triglycerides), but supporting growth of different microbial communities. Also the proportion of sulfate reducing bacteria was variable. Considering the minerals produced in natural settings, sulfate reducing bacteria consume organic matter, releasing bicarbonate and hydrogen sulfide. As modeled by Coleman et al., and Briggs (1993) and more recently expanded upon by Schiffbauer et al. (2014), the accumulation of sulfide in localized pore waters reacts with iron to precipitate iron sulfides such as pyrite. This sustains oxygen-free as well as reducing conditions in sediments. This supports preservation of lipids, as documented by studies of settings throughout the Phanerozoic (541 Ma to present, i.e. the time span of the fully oxygenated atmosphere and water body; Grice at al., 2019). Lipids are suitable fossil biomarkers when their structure reveals the specific source organism and when they are stable enough to retain their hydrocarbon skeletons in a way that 
the original molecule and its source may be reconstructed (Grice and Eiserbeck, 2014). As such, biomarkers allow for the detailed investigation of fossilization (Melendez et al., 2013a) and provide important information regarding microorganisms taking part in this process (Melendez et al., 2013b; Plet et al., 2016; Schwark, 2013). Though highly sulfidic conditions contribute to the preservation of organic matter (van Dongen et al., 2006), the microbes and processes that resulted in the carbonate deposition surrounding the fossil organic matter remains to be fully understood.

In the marine sediments, sulfate reduction takes place over a wide temperature range $\left(-3{ }^{\circ} \mathrm{C}\right.$ $40{ }^{\circ} \mathrm{C}$, cf. Finke and Jørgensen, 2008). However, most isolates are mesophiles with an optimum temperature at or above $30{ }^{\circ} \mathrm{C}$ (Knoblauch et al., 1999). It is also noted that cultivation time for sulfate reducers is almost 14 to 15 days at $30{ }^{\circ} \mathrm{C}$. Similarly, in the presented study, OTUs retrieved from mesocosms showed prominent sulfate reducing bacterial groups after 15 days (Kamran et al., 2020). It is evident that incubation temperature supports growth of different groups of sulfate reducers (Robador et al., 2016). Volatile, short chain fatty acids are the major organic substrate for most sulfate reducers. In contrast, members of the genus Desulfofrigus, that showed almost half of the abundance in mesocosm samples in the presented study, oxidizes longer chain fatty acids incompletely to acetate (Knoblauch et al., 1999). Scanning electron microscopy (SEM) coupled with energy dispersion spectrometry (EDS) are particularly useful to further characterize the elemental distribution and mineralogy of microstructures (Grice et al., 2019). The presented (scanning) transmission electron microscopic studies also demonstrate microorganisms involved in mineral adsorption: Bacterial morphotypes were observed with mineral accumulation at the cellular envelopes - particularly in the sample of triglyceride, Span 20 and Span 80. Though it is difficult to conclude which bacterial morphotype actively precipitates minerals or is just a target for mineral deposition, it could be shown that the mixed microbial community is in total involved in the process of mineral formation. 
Apparently, the mineralization is initiated at the surface of the bacterial cell. The applied techniques does not resolve structures at cell surfaces where initial mineral precipitates are formed, but apparently, nanometer scale layers of iron carbonate represent the first detectable step of mineral precipitation. The attachment of (bivalent) ions to biological molecules is said to be the initial step of microbially influenced mineralization (e.g., Görgen et al., 2021).

There are many observations of mineral precipitates on bacterial surfaces, with some rare examples for intracellular depositions. Considering sulfate reducing bacteria, mostly the formation of iron sulfides was observed, which may be simplified expressed as:

$\mathrm{Fe}^{2+}+\mathrm{H}_{2} \mathrm{~S} \rightarrow \mathrm{FeS}+\mathrm{H}^{+}$

with iron sulfate as precipitate. Fe (II) may be generated from Fe (III) by either biological (see below) or chemical reduction, e.g., by $\mathrm{H}_{2} \mathrm{~S}$ itself as a strong reducing agent. Sulfur may occur as sulfide $\left(\mathrm{S}^{2-}\right.$, iron sulfide or pyrrhotite) or disulfide $\left(\mathrm{S}_{2}{ }^{2-}\right.$, pyrite and mackinawite). The minerals may be converted into each other and hence may all result from microbial sulfate reduction (Duverger et al., 2020). The iron sulfides are visible by transmission electron microscopy, mostly surrounding microbial cells (e.g., Kokoschka et al., 2015; Berg et al., 2020), but also intracellularly. Generally, intracellular minerals are rare in prokaryotes, but intracellular greigite $\left(\mathrm{Fe}_{3} \mathrm{~S}_{4}\right)$ crystals have been observed (Reitner et al., 2005; Lefèvre et al., 2011). The magnetic particles are shaped and arranged like magnetosomes, but seem not to be involved in magnetotaxis: cells are fixed in a microbial biofilm and appear to be immotile (Wrede et al., 2013). The magnetosome particles are arranged in chains, as known from motile magnetotactic bacteria, but they are not aligned parallel to one another, which implies that the orientation along electromagnetic field lines is not of relevance. Though their original function may have been lost, they may be the (intracellular) byproduct of the otherwise extracellularly deposited iron sulfides. Their formation might detoxify the hydrogen sulfide, produced intracellularly as the end product of sulfate reduction, catalyzed by dissimilatory sulfite 
reductase and the DsrMJOP membrane complex (Strittmatter et al., 2009; Wenk et al., 2018). Bulk amounts of hydrogen sulfide may leave the cell by diffusion across the cell envelope and precipitate outside cells, but may still destroy, e.g., metal centers of enzymes when produced intracellularly. The detoxification by the highly controllable redox process of magnetosome formation, leading to greigite particles, may be an efficient way to remove residual hydrogen sulfide. Growing cells may not become intracellularly "lithified" by their own metabolic end product, as long as they grow and partition the magnetosomes to daughter cells. However, the chains may leave the cells after lysis and contribute to the formation of framboidal pyrite (Wrede et al., 2013). Generally, the occurrence of pyrite framboids is considered to be a proxy for biological sulfate reduction (e.g., Wacey et al., 2015).

Even when deposited extracellularly, encasement by iron sulfide minerals threatens microbial growth (Picard et al., 2018). In the present study, however, no iron sulfide mineral was detected, but instead, the iron carbonate siderite. As a straightforward hypothesis, oxidized iron may be considered as an electron acceptor for the sulfate reducing Desulfofrigus (Knoblauch et al., 1999; Kamran et al., 2020).

$\mathrm{Fe}^{3+}+\mathrm{CH}_{2} \mathrm{O} \rightarrow \mathrm{Fe}^{2+}{ }_{\text {aq }}+\mathrm{CO}_{2}$

with $\mathrm{CH}_{2} \mathrm{O}$ representing an organic substrate organic substrate in a simplified expression. Dissolvable reduced iron may form siderite, after reaction with carbonate ions, resulting from the respiratory activity of sulfate reducers.

$\mathrm{Fe}^{2+}{ }_{(\mathrm{aq})}+\mathrm{CO}_{3}{ }^{2-}{ }_{(\mathrm{aq})} \rightarrow \mathrm{FeCO}_{3}$

The removal of dissolved ferrous iron may contribute to a shift of the anaerobic iron respiration to the products, facilitating the whole process. However, also sulfur cycling must have occurred in the Desulfofrigus-dominated microcosms. Gas chromatography-mass spectrometry revealed the presence of elemental sulfur $\left(S_{8}\right)$ after $15 \mathrm{~d}$ of incubation (under nearly complete 
degradation of fatty acids; unpublished data, see appendix, page: $82-85)$. The reaction product is common for sulfur oxidizers, which could be also identified in the microcosms (namely Thiotrix- and Sulfurimonas-related OTUs, the latter among the four most abundant bacteria in the culture). It may be assumed that the sulfur originates from sulfate reduction and re-oxidation by the sulfur oxidizers in the dysoxic, but not anoxic culture. Electron microscopic analysis reveals the formation of siderite, but not iron sulfides, initially at cell surfaces, but then affecting and encasing whole cells. In this way whole cells are encased and killed like observed for formation of biogenic iron sulfide (Picard et al., 2018; Kamran et al., 2020). The encasement of cells by siderite has also been observed for the iron reducing Geobacter metallireducens (Roh et al., 2006).

\subsection{Carbonate precipitating alkaline spring}

The carbonate-precipitating system of the Voltri massif differs in many respects from siderite precipitating sediments. The host rock, i.e. the Voltri Massif (Ligurian Alps, $\mathrm{N}$ of Genova) is an ophiolitic complex. By active serpentinization of the ultramafic basement, highly alkaline ( $\mathrm{pH}$ up to 11.7) water from the deep underground discharges at the surface (Quéméneur et al., 2015). Geochemically and with respect to their deep biosphere microbial inventory, the rather small spring sites are partly similar to other terrestrial and submarine springs sustained by serpentinization (Schrenk et al., 2013; Suzuki et al., 2013). Previous studies of the prokaryotic diversity in springs revealed a mixture between OTUs from (putative) "deep biosphere" organisms, with, e.g., hydrogen and methane metabolizing abilities, but few cyanobacterial OTUs (Quéméneur et al., 2015).

In the study presented here, we focused on the intensively colonized 'green mats' associated with carbonates at spring sites (Kamran et al., 2021). The mats are dominated by filamentous cyanobacteria. Occasionally cyanobacterial filaments were preserved in calcitic precipitates of 
small sinter structures. Related cyanobacterial OTUs have been previously detected in various alkaline habitats, such as in microbialites of the alkaline Lake Alchichica, Mexico (Couradeau et al., 2011) and in microbial mats of the Del Puerto Ophiolite, California (Blank et al., 2009). Our data indicate that the photoautotrophic cyanobacteria are primary producers in Voltri springs (Boulart et al., 2013).

Besides these clearly non-deep biosphere organisms, a microbial "imprint" of putative deep biosphere organisms were seen, though none of them are necessarily obligate colonizers of an anaerobic deep biosphere habitat. One abundant organism, present in the alkaline spring is Hydrogenophaga. The genus has been separated from Pseudomonas (Willems et al., 1989) and comprises aerobic, facultatively hydrogen oxidizing chemoorganotrophic or chemolithoautotrophic Comamonadaceae, also capable of carbon monoxide oxidation (Willems et al., 1989; Schwartz et al., 2009). Some isolates of this genus are capable of growth above pH 9 (Roadcap et al., 2006). Hydrogenophaga was also shown to be the most abundant genus in ultrabasic springs of the Tablelands Ophiolite complexes (Brazelton, 2013). Several Hydrogenophaga species were also detected in Cabeço de Vide Aquifer (CVA) serpentinizing springs in Portugal (Tiago and Verissimo, 2013), where concentrations of dissolved hydrogen in the aquifer were low. According to the $16 \mathrm{~S}$ rRNA sequence, they were nearly identical to Hydrogenophaga-related OTUs from springs of the broader Voltri area (Quéméneur et al., 2015) and those detected in The Cedars serpentinization site, California (Suzuki et al., 2013). At these terrestrial sites - namely the Tablelands Ophiolite and The Cedars (Brazelton et al., 2013; Suzuki et al., 2014) - but also in a marine serpentinizing site (Prony Bay Hydrothermal Field, New Caledonia; Quéméneur et al., 2014), a new hyperalkaliphilic hydrogenotrophic genus, Serpentinomonas, closely related to Hydrogenophaga, has been defined by Suzuki et al., (2014). 
In the present study, a Hydrogenophaga-related OTU was by factors of 10 to 100 higher in the Voltri alkaline springs as compared to surface water. However, a consumption of hydrogen instead of an organic compound at sampling sites has not been shown and due to the fact that solubility of hydrogen in water is poor and equilibration against the atmosphere is fast, the availability of the (otherwise attractive) substrate is low at the sampling site. Though the abundance of the organism in the surface springs may be due to environmental parameters that have been hitherto not accessed, the high abundance of Hydrogenophaga in a deep subsurface aquifer fracture zone points to the relevance of this group of organisms as a successful colonizer of the deep biosphere (Purkamo et al., 2013). Another abundant Xanthomonadaceae bacteriumrelated OTU present in alkaline spring samples detected in Voltri spring samples may be as well facultatively autotrophic (Brazelton et al., 2017).

In the generally low diverse environment, there are few other bacterial groups of some abundance and certain relevance for the sites. The photoheterotrophic Rhodobacter (Alphaproteobacteria) metabolizes organic compounds as carbon source (instead of $\mathrm{CO}_{2}$ ), and uses sunlight for their energy requirements in the Voltri springs (Quéméneur et al., 2015). The abundance of some organisms like Tabrizicola (Tarhriz et al., 2013) cannot be explained; the presence of Cytophaga has been reported as being associated with cyanobacterial blooms (Gerphagnon et al., 2015).

\subsection{Synthesis and conclusion}

The both carbonate precipitating systems show two very distinct aspects of carbonate formation, illustrating two distinct pathways (of many), how carbonates are formed and how they encase organic compounds. In both cases, the precipitate encloses the (bacterial) cells and will kill them sooner or later. However, the participation of the microbial species in mineral formation is different. Iron carbonate formation at cell surfaces in enrichments of sulfate 
reducing bacteria are the result of a metabolically driven anaerobic respiratory process (of Desulfofrigus cells in this case). The observed encasement of cyanobacterial filaments is primarily a chemical process in the highly alkaline environment of the serpentinizing spring sites. Eventually, the cyanobacterial sheaths protect from immediate inclusion of the cell. The end point is in any case microbial biomass inside a carbonate, completely excluded from the environment and protected from degradation by other microbial cells. Hence, for fossilization of the microorganism itself and as well for a large multicellular structure surrounded by microorganisms during a decay process, inclusion in supersaturated carbonate precipitating systems is rather the "default" process than an exception. This contributes to an overall "background" of fossilized organisms (microbes in particular) in carbonate sediments and also a certain amount of preserved organics in carbonate sediments. When exposed to the surface, the organics will be set free and will be again part of a weathering process (cf. Loyd, 2017) and is subjected to microbial degradation (Saitta et al., 2019). As long as they are shielded against these recent effects, the fossilized macromolecules or isotopic signatures are important proxies for the last processes before the organic matter decay is stopped, but after re-exposition to recent microbes, these signals become rapidly overprinted (Saitta et al., 2019). This has to be taken account for all studies involving fossil biosignatures on Earth. On planetary surfaces which are definitely life-less (e.g., the surface of Mars), however, analysis of fossil organics in sedimentary rocks (shale, sandstone) may be a straightforward way to prove presence of extinct life (McMahon, 2018). 


\subsection{References}

Allison, P.A., Briggs, D.E.G. (1991) Taphonomy: Releasing the data locked in the fossil record. Plenum Press, New York.

Allison, P.A., Briggs, D.E.G. (1993) Exceptional fossils record: distribution of soft-tissue preservation through the Phanerozoic. Geology 21: 527-530.

Arp, G., Bissett, A., Brinkmann, N., Cousin, S., de Beer, D., Friedl, T., Mohr, K.I., Neu, T.R., Reimer, A., Shiraishi, F., Stackebrandt, E., Zippel, B. (2010) Tufa-forming biofilms of German karstwater streams: Microorganisms, exopolymers, hydrochemistry and calcification. Geological Society, London, Special Publications 336: 83-118.

Arp, G., Helms, G., Karlinska, K., Schumann, G., Reimer, A., Reitner, J. Trichet, J. (2012) Photosynthesis versus exopolymer degradation in the formation of microbialites on the atoll of Kiritimati, Republic of Kiribati, Central Pacific. Geomicrobiology Journal 29: 29-65.

Berg, J.S., Duverger, J., Cordier, L., Laberty-Robert, C., Guyot, F., Miot, J (2020) Rapid pyritization in the presence of a sulfur/sulfate-reducing bacterial consortium. Scientific Reports 10: 1-13.

Biddle, J. F., House, C. H., Brenchley, J. E. (2005) Microbial stratification in deeply buried marine sediment reflects changes in sulfate/methane profiles. Geobiology 3: 287-295.

Blank, J. G., Green, S. J., Blake, D., Valley, J. W., Kita, N. T., Treiman, A., Dobson, P. F. (2009) An alkaline spring system within the Del Puerto Ophiolite (California, USA): a Mars analog site. Planetary and Space Science 57: 533-540.

Boschi, C., Dini, A., Dallai, L., Ruggieri, G., Gianelli, G. (2009) Enhanced $\mathrm{CO}_{2}$-mineral sequestration by cyclic hydraulic fracturing and Si-rich fluid infiltration into serpentinites at Malentrata (Tuscany, Italy): Chemical Geology 265: 209-226.

Boulart, C., Chavagnac, V., Monnin, C., Delacour, A., Ceuleneer, G., Hoareau, G. (2013) Differences in gas venting from ultramafic-hosted warm springs: the example of Oman and Voltri ophiolites. Ofioliti 38: 142-156.

Brazelton, W. J., Thornton, C. N., Hyer, A., Twing, K. I., Longino, A. A., Lang, S. Q., Lilley, M.D., Früh-Green, G.L., Schrenk, M. O. (2017) Metagenomics identification of active methanogens and methanotrophs in serpentinite springs of the Voltri Massif, Italy. PeerJ 5: e2945. 
Brazelton, W.J., Morrill, P.L., Szponar, N., Schrenk, M.O. (2013) Bacterial communities associated with subsurface geochemical processes in continental serpentinite springs. Applied and Environmental Microbiology 79: 3906-3916.

Briggs, D. E. (2003) The role of decay and mineralization in the preservation of soft-bodied fossils. Annual Review of Earth and Planetary Sciences 31: 275-301.

Callow, R. H., Brasier, M. D. (2009) Remarkable preservation of microbial mats in Neoproterozoic siliciclastic settings: implications for Ediacaran taphonomic models. EarthScience Reviews 96: 207-219.

Canfield, D.E., Farquhar, J. (2009) Animal evolution, bioturbation, and the sulfate concentration of the oceans. Proceedings of the National Academy of Sciences 106: 8123-8127.

Coleman, M. L., Hedrick, D. B., Lovley, D. R., White, D. C., Pye, K. (1993) Reduction of $\mathrm{Fe}(\mathrm{III})$ in sediments by sulphate-reducing bacteria. Nature 361: 436-438.

Couradeau, E., Benzerara, K., Moreira, D., Gerard, E., Kaźmierczak, J., Tavera, R., LópezGarcía, P. (2011) Prokaryotic and eukaryotic community structure in field and cultured microbialites from the alkaline Lake Alchichica (Mexico). PLoS One 6: e28767.

Cui, Y., Jin, L., Ko, S. R., Chun, S. J., Oh, H. S., Lee, C. S.,Srivastava, A., Oh MH., Ahn, C. Y. (2017) Periphyton effects on bacterial assemblages and harmful cyanobacterial blooms in a eutrophic freshwater lake: a mesocosm study. Scientific Reports 7: 1-11.

Curtis, C.D., Coleman, M. L., Love L. G. (1986) Pore water evolution during sediment burial from isotopic and mineral chemistry of calcite, dolomite and siderite concretions. Geochimica et Cosmochimica Acta 50: 2321-2334.

Della Porta, G., Hoppert, M., Hallmann, C., Schneider, D., Reitner, J. (2021) The influence of microbial mats on travertine precipitation in active hydrothermal systems (Central Italy). The Depositional Record 00: 1-45.

Durand, N., Monger, H. C., Canti, M. G. (2010) Calcium carbonate features. In Interpretation of micromorphological features of soils and regoliths (eds. Stoops, G., Marcelino, V., Mees F.). Elsevier, Amsterdam, pp. 149-194.

Duverger, A., Berg, J. S., Busigny, V., Guyot, F., Bernard, S., Miot, J. (2020) Mechanisms of pyrite formation promoted by sulfate reducing bacteria in pure culture. Frontiers in Earth Science 8: 588310.

Finke, N., Jørgensen, B. (2008) Response of fermentation and sulfate reduction to experimental temperature changes in temperate and Arctic marine sediments. The ISME Journal 2: 815-829. 
Froelich, P. N., Klinkhammer, G. P., Bender, M. L., Luedtke, N. A., Heath, G. R., Cullen, D., Dauphin, P., Hammond, D., Hartman, B., Maynard, V. (1979) Early oxidation of organic matter in pelagic sediments of the eastern equatorial Atlantic: Suboxic diagenesis. Geochimica et Cosmochimica Acta 43: 1075-1090.

Fussmann, D., von Hoyningen-Huene, A., Reimer, A., Schneider, D., Babková H., Peticzka, R., Maier, A., Arp, G., Daniel, R., Meister, P. (2020) Authigenic formation of Ca-Mg carbonates in the shallow alkaline Lake Neusiedl, Austria. Biogeosciences 17: 2085-2106.

Gehling, J.G. (1999) Microbial mats in terminal Proterozoic siliciclastics: Ediacaran death masks. Palaios 14: 40-57.

Gerphagnon, M., Macarthur, D. J., Latour, D., Gachon, C. M., Van Ogtrop, F., Gleason, F. H., Sime-Ngando, T. (2015) Microbial players involved in the decline of filamentous and colonial cyanobacterial blooms with a focus on fungal parasitism. Environmental Microbiology 17: 2573-2587.

Gill, B.C., Lyons, T.W., Young, S.A., Kump, L.R., Knoll, A.H., Saltzman, M.R. (2011) Geochemical evidence for widespread euxinia in the later Cambrian ocean. Nature 469: 80-83.

Goldhaber, M. B., Kaplan, I. R. (1975) Controls and consequences of sulfate reduction rates in recent marine sediments. Soil Science 119: 42-55.

Görgen, S., Benzerara, K., Skouri-Panet, F., Gugger, M., Chauvat, F., Cassier-Chauvat, C. (2021) The diversity of molecular mechanisms of carbonate biomineralization by bacteria. Discover Materials 1: 1-20.

Grice, K., Eiserbeck, C. (2014) The analysis and application of biomarkers. In Treatise on Geochemistry (Second Edition) 12: Organic Geochemistry (eds. Falkowski, P.G., Freeman, K.H.). Elsevier, Oxford (UK), pp. 47-78.

Grice, K., Holman, A.I., Plet, C., Tripp, M. (2019) Fossilised Biomolecules and Biomarkers in Carbonate Concretions from Konservat-Lagerstätten. Minerals 9: 158.

Kamran, A., Sauter, A., Reimer, A., Wacker, T., Reitner, J., Hoppert, M. (2021) Cyanobacterial mats in calcite-precipitating serpentinite-hosted alkaline springs of the Voltri Massif, Italy. Microorganisms 9: 62.

Kamran, A., Schneider, D., Roddatis, V., Thiel, V., Hoppert, M. (2020) Formation of siderite in microbial microcosms derived from a marine sediment. Geomicrobiology Journal 37: 475485.

Kelemen, P.B., Matter, J. (2008) In situ carbonation of peridotite for $\mathrm{CO}_{2}$ storage. Proceedings of the National Academy of Sciences 105: 17295-17300. 
Knoblauch, C., Sahm, K., Jørgensen, B.B. (1999) Psychrophilic sulfate-reducing bacteria isolated from permanently cold Arctic marine sediments: description of Desulfofrigus oceanense gen. nov., sp. nov., Desulfofrigus fragile sp. nov., Desulfofaba gelida gen. nov., sp. nov., Desulfotalea psychrophila gen. nov., sp. nov. and Desulfotalea arctica sp. nov. International Journal of Systematic and Evolutionary Microbiology 49: 1631-1643.

Kokoschka, S., Dreier, A., Romoth, K., Taviani, M., Schafer, N., Reitner, J., Hoppert, M. (2015) Isolation of anaerobic bacteria from terrestrial mud volcanoes (Salse di Nirano, Northern Apennines, Italy). Geomicrobiology Journal 32: 355-364.

Laflamme, M., Schiffbauer, J.D., Narbonne, G.M., Briggs, D.E.G. (2011) Microbial biofilms and the preservation of the Ediacara biota. Lethaia 44: 203-213.

Lefèvre, C. T., Menguy, N., Abreu, F., Lins, U., Pósfai, M., Prozorov, T., Pignol, D., Frankel, R.B., Bazylinski, D. A. (2011) A cultured greigite-producing magnetotactic bacterium in a novel group of sulfate-reducing bacteria. Science 334: 1720-1723.

Lin, C. Y., Turchyn, A. V., Krylov, A., Antler, G. (2020) The microbially driven formation of siderite in salt marsh sediments. Geobiology 18: 207-224.

Loyd, S.J., Berelson, W.M. (2016) The modern record of concretionary carbonate: Reassessing a discrepancy between modern sediments and the geologic record. Chemical Geology 420: 77 87.

Loyd, S.J., Berelson, W.M., Lyons, T.W., Hammond, D.E., Corsetti, F.A. (2012) Constraining pathways of microbial mediation for carbonate concretions of the Miocene Monterey Formation using carbonate-associated sulfate. Geochimica et Cosmochimica Acta, 78: 77-98

Loyd. S.J. (2017) Preservation of overmature, ancient, sedimentary organic matter in carbonate concretions during outcrop weathering. Geobiology 15: 146-157.

McMahon, S. (2018) The chemistry of fossilization on Earth and Mars. Biochemistry 40: 2832.

Melendez, I., Grice, K., Schwark, L. (2013a) Exceptional preservation of Palaeozoic steroids in a diagenetic continuum. Scientific Reports 3: 1-6.

Melendez, I., Grice, K., Trinajstic, K., Ladjavardi, M., Greenwood, P., Thompson, K. (2013b) Biomarkers reveal the role of photic zone euxinia in exceptional fossil preservation: An organic geochemical perspective. Geology 41: 123-126.

Mozley, P.S., Burns, S.J. (1993) Oxygen and carbon isotopic composition of marine carbonate concretions, an overview. Journal of Sedimentary Research 63: 73-83. 
Muscente, A.D., Xiao, S. (2015a) New occurrences of Sphenothallus in the lower Cambrian of South China: Implications for its affinities and taphonomic demineralization of shelly fossils. Palaeogeography Palaeoclimatology Palaeoecology 437: 141-146.

Nealson, K. H. (1997) Sediment bacteria: Who's there, what are they doing, and what's new? Annual Review of Earth and Planetary Sciences 25: 403-434.

Nealson, K. H., and Saffarini, D. (1994) Iron and manganese in anaerobic respiration: environmental significance, physiology, and regulation. Annual Review of Microbiology 48: 311-343.

Picard, A., Gartman, A., Clarke, D. R., Girguis, P. R. (2018) Sulfate reducing bacteria influence the nucleation and growth of mackinawite and greigite. Geochimica et Cosmochimica Acta 220: 367-384.

Plet, C., Grice, K., Pagès, A., Ruebsam, W., Coolen, M. J. L., and Schwark, L. (2016) Microbially-mediated fossil-bearing carbonate concretions and their significance for palaeoenvironmental reconstructions: A multi-proxy organic and inorganic geochemical appraisal. Chemical Geology 426: 95-108.

Plet, C., Grice, K., Pagès, A., Verrall, M., Coolen, M. J., Ruebsam, W., Rickard, W.D.A., Schwark, L. (2017) Palaeobiology of red and white blood cell-like structures, collagen and cholesterol in an ichthyosaur bone. Scientific Reports 7: 1-10.

Purkamo, L., Bomberg, M., Nyyssönen, M., Kukkonen, I., Ahonen, L., Kietäväinen, R., Itävaara, M. (2013) Dissecting the deep biosphere: retrieving authentic microbial communities from packer-isolated deep crystalline bedrock fracture zones. FEMS Microbiology Ecology 85: 324-337.

Pye, K., Dickson, J.A.D., Schiavon, N., Coleman, M.L., Cox, M. (1990) Formation of sideriteMg-calcite-iron sulphide concretions in intertidal marsh and sandflat sediments, north Norfolk, England. Sedimentology 37: 325-343.

Quéméneur, M., Bes, M., Postec, A., Mei, N., Hamelin, J., Monnin, C., Chavagnac, V., Payri, C., Pelletier, B., Guentas-Dombrowsky, L., Gérard, M., Pisapia, C., Gérard, E., Ménez, B., Ollivier, B., Erauso, G. (2014) Spatial distribution of microbial communities in the shallow submarine alkaline hydrothermal field of the Prony Bay, New Caledonia. Environmental Microbiology Reports 6: 665-674.

Quéméneur, M., Palvadeau, A., Postec, A., Monnin, C., Chavagnac, V., Ollivier, B., Erauso, G. (2015) Endolithic microbial communities in carbonate precipitates from serpentinite-hosted hyperalkaline springs of the Voltri Massif (Ligurian Alps, Northern Italy). Environmental Science and Pollution Research 22: 13613-13624. 
Raiswell, R. (1987) Non-steady state microbiological diagenesis and the origin of concretions and nodular limestones. Geological Society, London, Special Publications 36: 41-54.

Reeburgh, W. S. (1983) Rates of biogeochemical processes in anoxic sediments. Annual Review of Earth and Planetary Sciences 11: 269-298.

Reitner, J. (2004) Organomineralization. In: Origins. Cellular Origin, Life in Extreme Habitats and Astrobiology, 6. Springer, Dordrecht. pp. 195-212.

Reitner, J., Peckmann, J., Reimer, A., Schumann, G., Thiel, V. (2005) Methane-derived carbonate build-ups and associated microbial communities at cold seeps on the lower Crimean shelf (Black Sea). Facies 51: 66-79.

Roadcap, G. S., Sanford, R. A., Jin, Q., Pardinas, J. R., Bethke, C. M. (2006) Extremely alkaline $(\mathrm{pH}>12)$ ground water hosts diverse microbial community. Groundwater 44: 511-517.

Robador, A., Müller, A., Sawicka, J., Berry, D., Hubert, C. R. J., Loy, A., Jørgensen, B.B., Brüchert V. (2016) Activity and community structures of sulfate-reducing microorganisms in polar, temperate and tropical marine sediments. The ISME journal 10: 796-809.

Roh, Y., Gao, H., Vali, H., Kennedy, D. W., Yang, Z. K., Gao, W. Dohnalkova, A., Stapleton, R.D., Moon, JW., Phelps,T.J., Fredrickson, J.K., Zhou, J. (2006) Metal reduction and iron biomineralization by a psychrotolerant Fe (III)-reducing bacterium, Shewanella sp. strain PV4. Applied and Environmental Microbiology 72: 3236-3244.

Saitta, E.T., Liang, R., Lau, M.C.Y., Brown, C.M., Longrich, N.R., Kaye, T.G., Novak, B.J., Salzberg, S.L., Norell, M.A., Abbott, G.D., Dickinson, M.R., Vinther, J., Bull, I.D., Brooker, R.A., Martin, P., Donohoe, P., Knowles, T.D.J., Penkman, K.E.H., Onstott, T. (2019) Cretaceous dinosaur bone contains recent organic material and provides an environment conducive to microbial communities. Elife 8: e46205.

Schiffbauer, J. D., Xiao, S., Cai, Y., Wallace, A. F., Hua, H., Hunter, J., Xu, H., Peng, Y., Kaufman, A. J. (2014) A unifying model for Neoproterozoic-Paleozoic exceptional fossil preservation through pyritization and carbonaceous compression. Nature Communications $\mathbf{5}$ : $1-12$.

Schrenk, M. O., Brazelton, W. J., and Lang, S. Q. (2013) Serpentinization, carbon, and deep life. Reviews in Mineralogy and Geochemistry 75: 575-606.

Schwark, L. (2013) Exceptional preservation of microbial lipids in Paleozoic to Mesoproterozoic sediments. Geology 41: 287-288.

Schwartz, E. (2009) Megaplasmids of aerobic hydrogenotrophic and carboxidotrophic bacteria. In Microbial Megaplasmids Springer, Berlin, Heidelberg. pp. 239-270. 
Schwarzenbach, E. M., Früh-Green, G. L., Bernasconi, S. M., Alt, J. C., and Plas, A. (2013) Serpentinization and carbon sequestration: A study of two ancient peridotite-hosted hydrothermal systems. Chemical Geology 351: 115-133.

Sellés-Martínez, J. (1996) Concretion morphology, classification and genesis. Earth-Science Reviews 41: 177-210.

Sperling, E.A., Wolock, C.J., Morgan, A.S., Gill, B.C., Kunzmann, M., Halverson, G.P., Macdonald, F.A., Knoll, A.H., Johnston, D.T. (2015) Statistical analysis of iron geochemical data suggests limited late Proterozoic oxygenation. Nature 523: 451-454.

Strittmatter, A. W., Liesegang, H., Rabus, R., Decker, I., Amann, J., Andres, S., Henne, A. Fricke, W. F., Martinez-Arias, R., Bartels, D., Goesmann, A., Krause, L., Pühler, A., Klenk, HP., Richter, M., Schüler, M., Glöckner, F.O., Meyerdierks, A., Gottschalk, G., Amann, R. (2009) Genome sequence of Desulfobacterium autotrophicum HRM2, a marine sulfate reducer oxidizing organic carbon completely to carbon dioxide. Environmental Microbiology 11: 10381055 .

Suzuki, S., Ishii, S. I., Wu, A., Cheung, A., Tenney, A., Wanger, G., Kuenen J.G., Nealson, K. H. (2013) Microbial diversity in The Cedars, an ultrabasic, ultrareducing, and low salinity serpentinizing ecosystem. Proceedings of the National Academy of Sciences 110: 15336-15341.

Suzuki, S., Kuenen, J. G., Schipper, K., Van Der Velde, S., Ishii, S. I., Wu, A. Sorokin, D.Y., Tenney, A., Meng, X.Y., Morrill, P.L., Kamagata, Y., Muyzer, G., Nealson, K. H. (2014) Physiological and genomic features of highly alkaliphilic hydrogen-utilizing Betaproteobacteria from a continental serpentinizing site. Nature Communications 5: 1-12.

Tarhan, L.G., Droser, M.L., Planavsky, N.J., Johnston, D.T. (2015) Protracted development of bioturbation through the early Palaeozoic Era. Nature Geoscience 8: 865-869.

Tarhriz, V., Thiel, V., Nematzadeh, G., Hejazi, M. A., Imhoff, J. F., Hejazi, M. S. (2013) Tabrizicola aquatica gen. nov. sp. nov., a novel alphaproteobacterium isolated from Qurugöl Lake nearby Tabriz city, Iran. Antonie van Leeuwenhoek 104: 1205-1215.

Tiago, I., Verissimo, A. (2013) Microbial and functional diversity of a subterrestrial high pH groundwater associated to serpentinization. Environmental Microbiology 15: 1687-1706.

van Dongen, B. E., Schouten, S., Sinninghe Damsté, J. S. (2006) Preservation of carbohydrates through sulfurization in a Jurassic euxinic shelf sea: Examination of the Blackstone Band TOC cycle in the Kimmeridge Clay Formation, UK. Organic Geochemistry 37: 1052-1073.

Wacey, D., Kilburn, MR., Saunders, M., Cliff, J.B., Kong, C., Liu, A.G., Matthews, J.J., Brasier, M. (2015) Uncovering framboidal pyrite biogenicity using nano-scale $\mathrm{CN}_{\text {org }}$ mapping. Geology 43: 27-30. 
Welte D.H. (1969) Organic Matter in Sediments. In: Eglinton G., Murphy M.T.J. (eds) Organic Geochemistry. Springer, Berlin, Heidelberg. pp. 262-264.

Wenk, C. B., Wing, B. A., Halevy, I. (2018) Electron carriers in microbial sulfate reduction inferred from experimental and environmental sulfur isotope fractionations. The ISME Journal 12: 495-507.

Wilby, P. R., Briggs, D. E. G., Bernier, P., Gaillard, C. (1996) Role of microbial mats in the fossilization of soft tissues. Geology 24: 787-790.

Willems, A., Busse, J., Goor, M., Pot, B., Falsen, E., Jantzen, E., Hoste B., Gillis M., Kersters K., Auling G., De Ley, J. (1989) Hydrogenophaga, a new genus of hydrogen-oxidizing bacteria that includes Hydrogenophaga flava comb. nov. (formerly Pseudomonas flava), Hydrogenophaga palleronii (formerly Pseudomonas palleronii), Hydrogenophaga pseudoflava (formerly Pseudomonas pseudoflava and "Pseudomonas carboxydoflava"), and Hydrogenophaga taeniospiralis (formerly Pseudomonas taeniospiralis). International Journal of Systematic and Evolutionary Microbiology 39: 319-333.

Wrede, C., Kokoschka, S., Dreier, A., Heller, C., Reitner, J., Hoppert, M. (2013) Deposition of biogenic iron minerals in a methane oxidizing microbial mat. Archaea, 2013: 102972. 


\section{Appendix}

\section{A) Supplement: Detection of substrates and products in microcosms by mass spectrometry}

\section{Methods}

Samples from microcosms with most obvious formation of siderite around cells (with Span 20 and Span 80 as substrates, cf. Kamran et al., 2020) were prepared for mass spectrometry (cf. Wittenborn et al., 2020). For this, samples taken from freshly inoculated microcosms and from microcosms after an incubation time of $15 \mathrm{~d}$ were lyophilized. The product was homogenized with mortar and pestle and subjected to extraction with a mixture of dichloromethane (DCM) and methanol (M): After dispersion of $200 \mathrm{mg}$ of lyophilisate in $2 \mathrm{ml}$ solvent (2 parts DCM, 1 part $\mathrm{M} ; \mathrm{v} / \mathrm{v}$ ), the mixture was sonicated for $8 \mathrm{~min}$ in an ultrasonic bath and centrifuged for 5 min. The supernatant was collected. Extraction, ultrasonication and centrifugation were repeated with a 3 parts DCM / 1 part M mixture as solvent and finally with pure DCM. All supernatants were combined and concentrated in a rotary evaporator. For derivatization, a dry sample aliquot was dissolved in trimethylchlorosilan / methanol ( 9 parts, 1 part; v/v), subsequently incubated at $80{ }^{\circ} \mathrm{C}$ for $90 \mathrm{~min}$ and extracted three times with $1 \mathrm{ml}$ hexane. Supernatants were combined and the solvent was evaporated to near-dryness.

Gas chromatography-mass spectrometry (GC-MS) analysis was performed in a Thermo Fisher Trace 1310 gas chromatograph equipped with a Quantum XLS ultra mass spectrometer on a fused-silica capillary column (Phenomenex Zebron ZB-5MS, $30 \mathrm{~m}, 0.1 \mu \mathrm{m}$ film thickness, inner diameter $0.25 \mathrm{~mm}$ ) with helium as carrrier gas (flow rate $1.5 \mathrm{ml} / \mathrm{min}$; temperature program: $80{ }^{\circ} \mathrm{C}$ for $1 \mathrm{~min}$, ramp to $310{ }^{\circ} \mathrm{C}$ at a rate of $5^{\circ} \mathrm{C} / \mathrm{min}, 20 \mathrm{~min}$ at $310{ }^{\circ} \mathrm{C}$ ). Recording 
of mass spectra were performed at $70 \mathrm{eV}$ electron energy. Identification of peaks was done by correlation of retention times with an internal database and standard compounds for calibration.

\section{Results}

Span 20 ("sorbitan monolaurate") consists a mixture of $\mathrm{C}_{12}-\mathrm{C}_{18}$ fatty acids esterified with head groups derived from the sugar alcohol sorbitol. Span 80 ("sorbitan monooleate") mainly consists of oleic acid with the same head groups. The compounds can be dispersed in water and are therefore easily accessible to microbial degradation.

Preparations from freshly inoculated Span 80 microcosms show one prominent fatty acid peak (oleic acid; Fig. 1 a). Preparations from Span 20 microcosms, freshly inoculated prior to degradation ("original" in Fig 2. a) showed distinct peaks for lauric acid (12), myristic acid (14), palmitic acid (16), oleic acid (18:1) and stearic acid (18). After $15 \mathrm{~d}$ of incubation, for both microcosms a prominent peak assignable to $S_{8}$ rings ("degraded") is observed (Fig. $1 \mathrm{~b}$ and 2 b). Sorbitan fatty acid esters were apparently completely degraded in Span 20 microcosms. Chromatograms for Span 80 microcosms show an additional peak representing palmitic acid (16). Elemental sulfur may be produced from sulfite (which is an intermediate of sulfate reduction) or sulfide (end product of sulfate reduction), after re-oxidation by thiotrophic bacteria. 


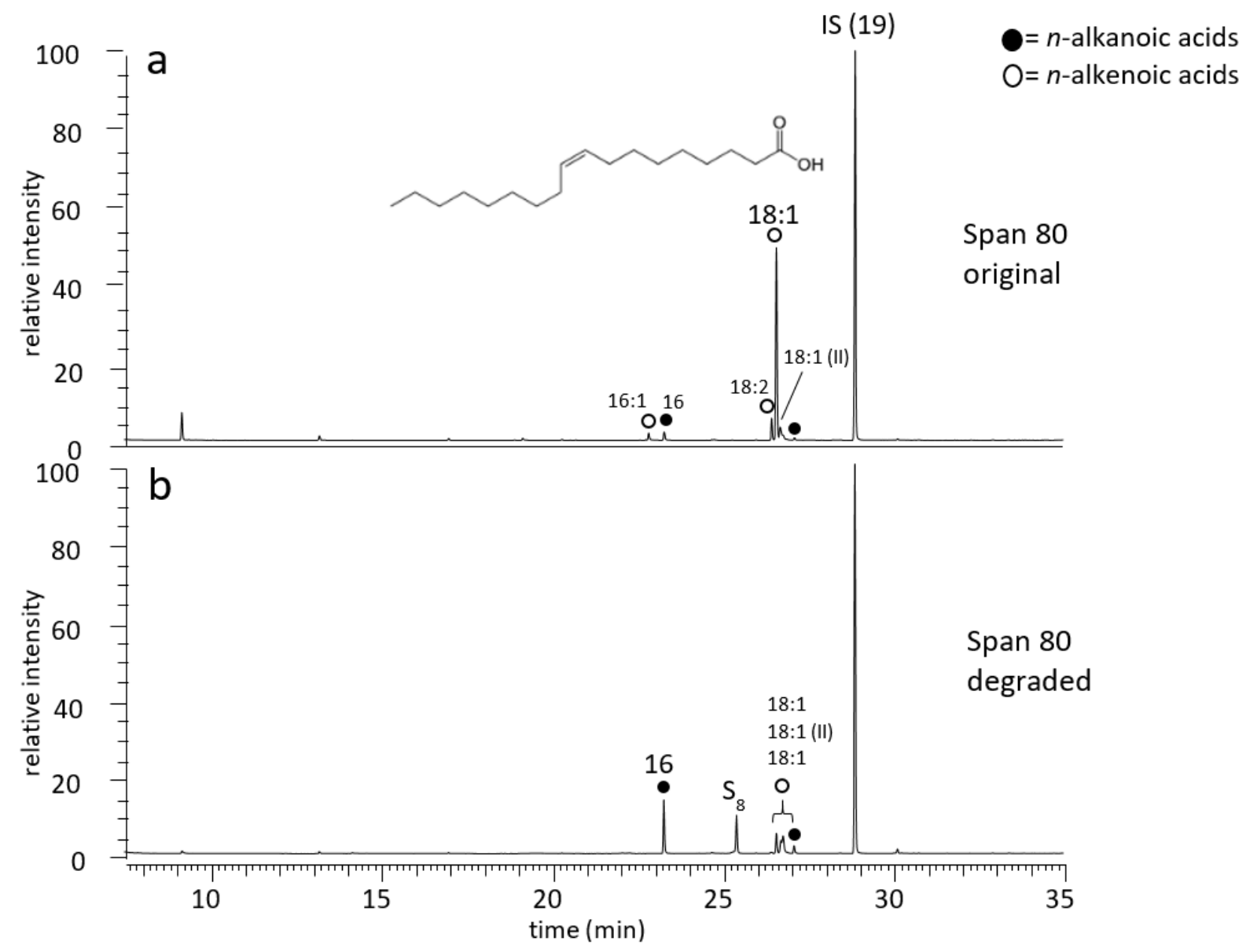

Fig. 1. GC-MS chromatograms of fatty acids from Span 80 microcosms. Numbers above peaks refer to numbers of carbon atoms in fatty acids. a) After inoculation of the microcosm prior to microbial degradation (original). The most prominent oleic acid is depicted as a formula. b) After $15 \mathrm{~d}$ of incubation (degraded) with a prominent palmitic acid peak (16) and a peak representing elemental sulfur $\left(\mathrm{S}_{8}\right)$. 


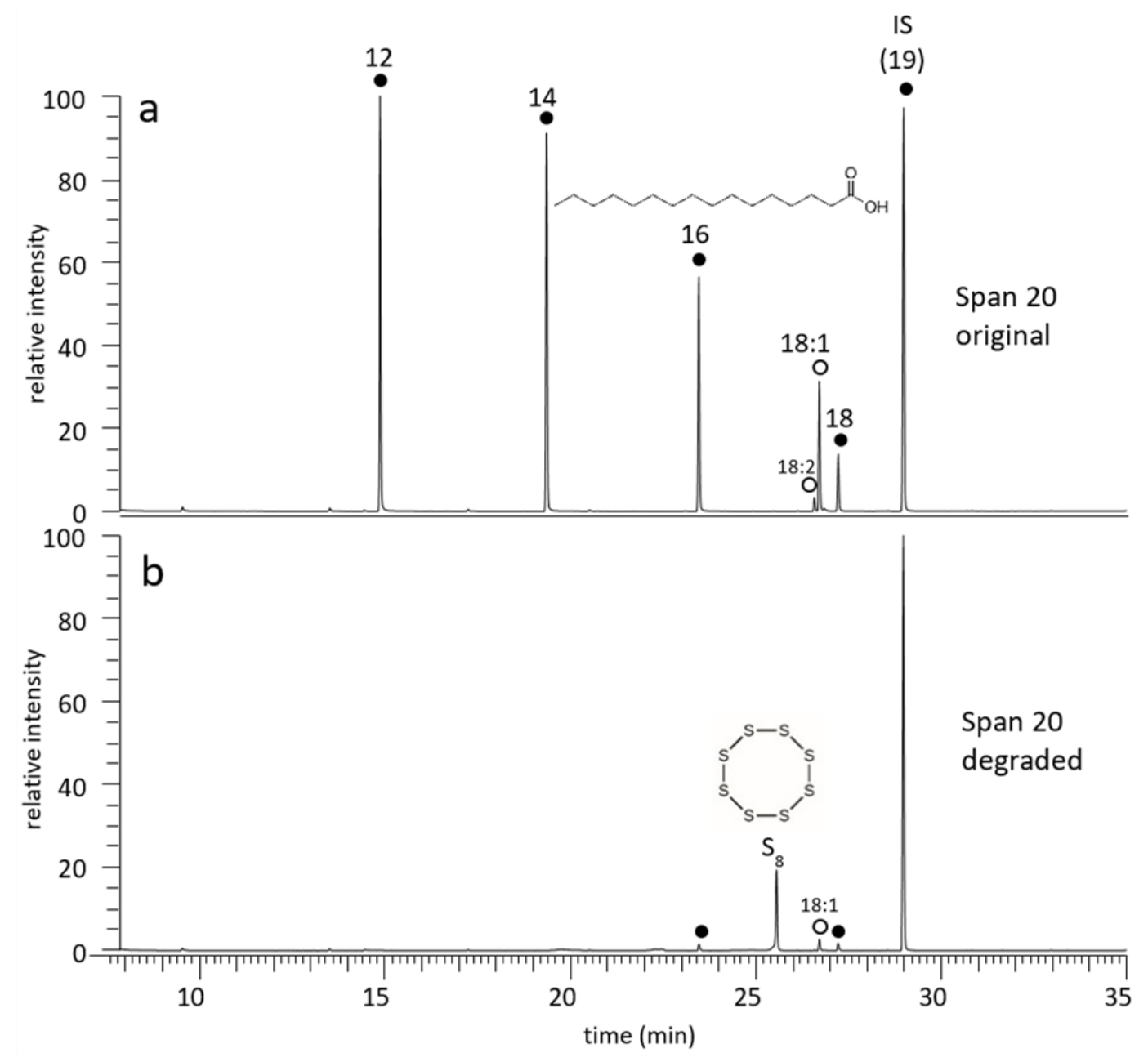

Fig. 2. GC-MS chromatograms of fatty acids from Span 20 microcosms. Numbers above peaks refer to numbers of carbon atoms in fatty acids; see fig 1 for further symbols. a) After inoculation of the microcosm prior to microbial degradation (original). Palmitic acid is depicted as a formula. b) After 15 $\mathrm{d}$ of incubation (degraded) with a peak representing elemental sulfur $\left(\mathrm{S}_{8}\right)$.

\section{References}

Kamran, A., Schneider, D., Roddatis, V., Thiel, V., Hoppert, M. (2020) Formation of siderite in microbial microcosms derived from a marine sediment. Geomicrobiology Journal 37: 475485 .

Wittenborn, A. K., Schmale, O., Thiel, V. (2020) Zooplankton impact on lipid biomarkers in water column vs. surface sediments of the stratified Eastern Gotland Basin (Central Baltic Sea). Plos one 15: e0234110. DOI: 10.1371/journal.pone.0234110 


\section{B) Conference participations}

Aysha Kamran, Volker Thiel, Vladimir Roddatis, Dominik Schneider, Michael Hoppert (2018) Carbonate mineralization process for the preservation of organic solids. $15^{\text {th }}$ Horizons in Molecular Biology, 10-18 Sep 2018, Göttingen, Germany. Poster.

Aysha Kamran, Volker Thiel, Dominik Schneider, Michael Hoppert (2018) Microbially induced mineral precipitation and fossil formation in marine sediments. The $17^{\text {th }}$ International Symposium on Microbial Ecology ISME, 18-17 Aug 2018, Leipzig, Germany. Poster.

Aysha Kamran (2018) A gemstone in the heart of stone (Microbiology). I, Scienist, 25-26 May 2018, Berlin, Germany. Science slam presentation.

Aysha Kamran, Dominik Schneider, Volker Thiel, Michael Hoppert (2018) Microbial mineral precipitation: A smart tool in fossil preservation. Annual Conference of the Association for General and Applied Microbiology (VAAM), 15-18 April 2018, Wolfsburg, Germany. Poster.

\section{C) Publications (during doctoral study)}

A Kamran, K Sauter, A Reimer, T Wacker, J Reitner, M Hoppert (2021) Cyanobacterial mats in in calcite precipitating serpentinite-hosted alkaline springs of the Voltri Massif, Italy. Microorganisms 9, 9010062. DOI: 10.3390/microorganisms 9010062

B Dörnte, C Peg, Z Fang, A Kamran, C Yulvizar, U Kües (2020) Selection markers for transformation of the sequenced reference monokaryon Okayama 7/\#130 and homokaryon AmutBmut of Coprinopsis cinerea. Fungal Biol Biotechnol 7, 15. DOI: 10.1186/s40694-020$\underline{00105-0}$

A Kamran, D Schneider, V Roddatis, V Thiel, M Hoppert (2020) Formation of siderite in microbial microcosms derived from marine sediment. Geomicrobiol J 37, 475-485 DOI: $\underline{10.1080 / 01490451.2020 .1725186}$

I M Willms, A Kamran, N F Aßmann, D Krone, S H Bolz, F Fiedler, H Nacke (2019) Discovery of novel antibiotic resistance determinants in forest and grassland soil metagenomes. Front Microbiol 10, 460. DOI: 10.3389/fmicb.2019.00460 


\section{Declaration}

I hereby declare that this thesis has been written independently, with use of the sources and aids than those cited.

Aysha Kamran

Göttingen, 30.11.2021 


\section{Acknowledgement}

This dissertation is a major milestone in my academic career. It has been a great privilege to convey my earnest feelings, pay heartfelt homage and express my thanks to all those with whom I shared several vital and unforgettable years and who have guided and supported me throughout the research process and provided assistance for my venture.

First and foremost, I am obliged to the Almighty ALLAH, for showering HIS blessings and enabling me for this honor.

After that I would like to present my amplest gratefulness to my supervisor Dr. Michael Hoppert for his scientific guidance throughout my doctoral studies. I am highly inspired by his scientific approach and knowledge. I am also thankful to him for correction of my manuscripts and my doctoral thesis. He not only guided me in his subject area but also supported me to explore further research projects. I am overwhelmed that I got this opportunity to collaborative work and internships. This confidence and experience I gained under his supervision is highly valuable and I believe will be helpful in my future career. I am obliged to the University of Karachi, Karachi-Pakistan, Dr. Hoppert and the University of Göttingen for the funding of my doctorate study within their limited resources and providing help whenever needed.

Furthermore, I express my deep gratitude to Prof. Dr. Volker Thiel with whom I had multiple discussions. I am thankful for valuable suggestions from him during my research work. I also thank the technical contributions of Ms Cornelia Conradt from his lab in sample analysis by mass spectrometry.

I am also thankful for Prof. Dr. Rolf Daniel for his presence as supervisor and great suggestions during thesis committee meetings.

I am extremely thankful to all respected board members for accepting the request for reviewing and evaluating my thesis. I am thankful to Prof. Dr. Reitner, Dr. Liesegang and Dr. Kramer for reviewing and their help to enhance the quality of my thesis.

I would like to express my gratitude towards all collaborators. I would like to thank Dr. Anja Poehlein for performing sample sequencing. Especially, I would like to thank Dr. Dominik Schneider and Kathrin Sauter for bioinformatics analysis of sequencing data. So, I was able to publish my publications timely with their expertise. Moreover, I am thankful to Dr. Andreas Reimer for water chemistry analysis of my samples collected from Voltri Massif. I am thankful to Dr. Vladimir Roddatis to facilitate for scanning transmission electron microscopy of my samples. I am thankful to Prof. Dr. Joachim Reitner for his reviewing and comments on my research article.

I would like to mention my Italy excursion, a part of my doctoral study, with Dr. Hoppert and Dr. Heiko Nacke. It was a great experience and exposure to many natural phenomena with outstanding team. I am further thankful to Theresa Wacker for sample collection and storage 
during the trip. I am really thankful to my lab colleague Dr. Sania and Elias for their support during experiments and other lab work. Above all, I would like to thank my friend Dr. Aneeqa Noor. Her moral support and suggestions was a secret treasure of happiness all over my stay in Göttingen. Apart from pandemic and the lockdown situation, cheerful support of Dr. Hira Niazi especially during last months of this doctoral study.

Last but not least, I am very thankful to all my family members, especially my parents. I am extremely grateful to my sweet sisters Sidra and Mehak for their love and elongated phone calls. I appreciate the value-added suggestions of my sister Nida during my studies. I am thankful to my brothers Aman and Subhan for their moral support. I feel blessed by their presence in my life. I highly appreciate the understanding and support of my husband Kamran for my career and study. Finally, I would like to dedicate my doctoral thesis to my loved ones, my children, Muhammad Arham and Muhammad Ibrahim. Their presence not only provides me with strength and courage but also filled brightness in my life. I believe that every situation and person come into life with some purpose.

Here is to closing old chapters and opening new chapters in life. 